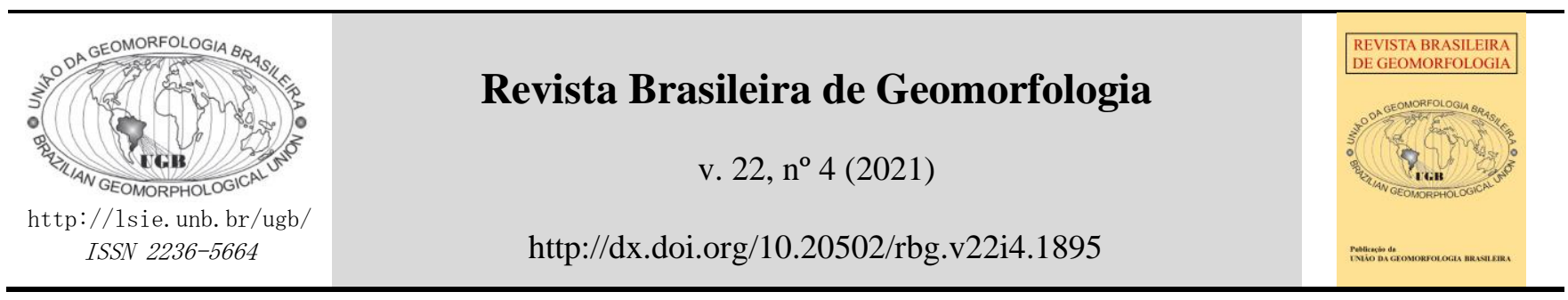

Artigo de Revisão

\title{
Evolução das bases teóricas e metodológicas para identificação das mudanças, oscilações e pulsações climáticas
}

\section{Evolution of theoretical and methodological bases for identification of climatic changes, oscillations and pulsations}

\section{Felipe Gomes Rubira ${ }^{1}$ e Archimedes Perez Filho ${ }^{2}$}

1 Universidade Federal de Alfenas, Departamento de Geografia, Alfenas, Brasil. felipe.rubira@unifal-mg.edu.br ORCID: https://orcid.org/0000-0002-6594-8228

2 Universidade Estadual de Campinas, Departamento de Geografia, Campinas, Brasil. archi@ige.unicamp.br ORCID: https://orcid.org/0000-0001-6675-3740

Recebido: 30/03/2020; Aceito: 31/05/2021; Publicado: 01/10/2021

Resumo: O desenvolvimento deste artigo surge em razão da distinção conceitual entre três grandes grupos de eventos climáticos baseados na durabilidade e ciclicidade temporal de determinada tendência dos fenômenos atmosféricos: mudanças climáticas, oscilações climáticas e pulsações climáticas. Assim, objetiva evidenciar cronologicamente a evolução de algumas bases teóricas-metodológicas responsáveis pela identificação de episódios paleoclimáticos vinculados aos conceitos estabelecidos. A análise foi conduzida de modo a destacar as primeiras constatações de eventos glaciais e interglaciais (mudanças climáticas), abordando antigas nomenclaturas e técnicas de identificação pautadas em datações relativas. A posteriori são promovidas discussões sobre a revolução dos isótopos cosmogênicos, responsável pelo aperfeiçoamento do reconhecimento das mudanças climáticas e primeiras identificações de oscilações climáticas. Trata-se especificamente dos estudos das razões de isótopos de oxigênio $\left({ }^{16} \mathrm{O},{ }^{18} \mathrm{O}\right)$ em foraminíferos de leitos marinhos, bem como das novas nomenclaturas desenvolvidas. Por fim, são abordadas discussões teóricas que evidenciam subsídios metodológicos das Geociências para identificação de pulsos climáticos de curta duração, ocorridos em escala de tempo recente da natureza a partir de distintos métodos de datação aplicados em inúmeros proxies/registros existentes. Verifica-se aperfeiçoamento da identificação de eventos paleoclimáticos de diferentes durabilidades e ciclicidades temporais, condizente com refinamentos metodológicos impulsionados por avanços tecnológicos inerentes às Ciências da Terra.

Palavras-chave: Proxies ambientais; datações absolutas; reconstruções paleoclimáticas.

\begin{abstract}
The development of this paper arises from the conceptual distinction between three major groups of climate events based on the durability and temporal cyclicity of a given trend of atmospheric phenomena (climate changes, climate oscillations and climate pulsations). Thus, it aims to chronologically highlight the evolution of some theoreticalmethodological bases responsible for the identification of paleoclimatic episodes linked to the established concepts. The analysis was conducted to highlight the first identifications of glacial and interglacial events (climate changes), addressing old nomenclatures and identification techniques based on relative dates. Posteriorly, discussions about the cosmogenic isotope revolution are promoted, responsible for improving the recognition of climate change and early identification of climatic oscillations. It stands out specifically studies of the oxygen isotope ratios $\left({ }^{16} \mathrm{O},{ }^{18} \mathrm{O}\right)$ in foraminifera of seabeds, as well as the new nomenclatures developed. Finally, theoretical discussions are approached that show methodological subsidies from Geosciences for the identification of short-term climatic pulses, that occurred in a recent time scale of nature from different dating methods applied in numerous existing proxies/records. There is an improvement in the identification of paleoclimatic
\end{abstract}


events of different durations and time cycles, consistent with methodological refinements driven by technological advances inherent in Earth Sciences.

Keywords: Environmental proxies; absolute dating; paleoclimatic reconstructions.

\section{Introdução}

A sintetização dos avanços metodológicos e dos conhecimentos adquiridos sobre os eventos paleoclimáticos do Quaternário, abordando e sistematizando os resultados de várias pesquisas, como o presente estudo propõe, apresenta-se extremamente relevante para que geomorfólogos compreendam e reconheçam processos intimamente relacionados à morfogênese de diversas superfícies geomorfológicas, sejam elas continentais ou costeiras. O reconhecimento do ritmo e intensidade dos principais eventos climáticos, que ocorreram no Quaternário, fornecem subsídios teóricos fundamentais para diversas interpretações evolutivas do relevo.

Algumas teorias elaboradas para tentar explicar à ciclicidade climática foram apresentadas por Bigarella, Mousinho e Silva (1965), como a teoria astronômica de Milankovitch (1920), que sustenta à hipótese de que as glaciações são consequências de reduções da constante solar, provocadas pelas variações nos elementos da órbita terrestre, como a excentricidade, obliquidade da eclíptica e precessão dos equinócios. Fatores que provocariam resfriamentos no planeta pela diminuição da temperatura global. Nesta linha de raciocínio, Goudie (1983) salienta que causas terrestres também poderiam ser responsáveis pela alteração da dinâmica da circulação atmosférica, como o deslocamento dos continentes em direção aos polos, a própria massa e composição do ar e eventos vulcânicos capazes de bloquear parte da radiação solar.

A partir destas premissas, Perez Filho e Rubira (2019) distinguiram conceitualmente três grandes grupos de eventos climáticos baseados na durabilidade e ciclicidade temporal de determinada tendência dos fenômenos atmosféricos, sendo eles: mudanças climáticas, oscilações climáticas e pulsações climáticas.

Nesta perspectiva, o conceito de mudanças climáticas contempla eventos complexos de maior duração e abrangência espacial (findados em máximos glaciais e auges interglaciais globais), como por exemplo, as quatro glaciações quaternárias identificadas por Penck e Brückner (1909), que ocorreram após longo período de aquecimento durante o Paleógeno/Neógeno, na passagem do Plioceno para o Pleistoceno, ocasionando arrefecimentos globais de até $6^{\circ} \mathrm{C}$. Tais eventos tiveram ciclicidade de aproximadamente 120 mil anos ao longo dos últimos 800 mil anos e, mais curtas antes disso, estando associados aos estágios de isótopos marinhos determinados pioneiramente por Emiliani (1955) e, posteriormente padronizados por Railsback (2015) e Railsback et al. (2015a, 2015b), mediante representação por números pares (Last Glacial Maximum) e ímpares (Climatic Optimum).

Ao passo que o conceito de oscilações climáticas se vincula a eventos de média duração que ocorreram no Pleistoceno, representando variações climáticas de temperatura abruptas (oscilações climáticas) situadas temporalmente entre picos extremos de estágios glaciais e interglaciais bem definidos (mudanças climáticas). Tais eventos climáticos seriam caracterizados pela interrupção de contínuos descensos do nível relativo do mar até máximos glaciais ou permanentes elevações marinhas até optimum climáticos e, portanto, também estariam correlacionadas às mudanças do volume global de gelo.

Neste conceito se agrupariam os eventos Heinrich, associados às quedas de temperaturas do ar no Ártico (HEINRICH, 1988); os eventos Dansgaard-Oeschger, caracterizados pelo aumento de temperaturas do ar no Ártico (DANSGAARD et al. 1993); o evento de aquecimento Bølling-Allerød Warming (HARTZ; MILTHERS, 1901; JESSEN, 1935; IVERSEN, 1942) e os eventos de resfriamentos Oldest Dryas, Older Dryas e Younger Dryas (HARTZ; MILTHERS, 1901; XIAODONG; LIWEI; SHUJI, 2014). Deste modo, o conceito de oscilações climáticas se associaria 
aos subestágios isotópicos marinhos propostos pioneiramente por Shackleton (1969) e, posteriormente padronizados por Railsback (2015) e Railsback et al. (2015a, 2015b) mediante representação por letras.

O conceito de pulsações climáticas se relaciona a eventos de curta duração (ciclos máximos de 2.000 anos), ocorridos em escala de tempo recente (Pleistoceno Superior e Holoceno), os quais não necessariamente teriam relação direta com mudanças do volume global de gelo, podendo ocorrer com ritmos e intensidades diferentes entre diversos sistemas ambientais contextualizados em zonas climáticas divergentes. Neste conceito, por exemplo, se agrupariam os eventos Bond, correlacionados aos pulsos climáticos de resfriamentos no Atlântico Norte, com ocorrência no Holoceno (BOND et al., 1997).

Também pode-se citar como exemplo, em relação aos últimos 2.500 anos, atuação de pulsos climáticos de aquecimento como o Roman Warm Period por volta de 2.500 a 1.600 anos A.P. (LAMB, 1965; WANG; SURGE; WALKER, 2013), Medieval Warm Period por volta de 1.050 a 600 anos A.P. (HUGHES; DIAZ, 1994; GRAHAM et al., 2011) e Current Warm Period nos últimos 170 anos A.P. (TAYLOR, 2010; VUILLE et al., 2012; CUÑA-RODRÍGUEZ et al., 2020). Interrompidos por breves episódios climáticos responsáveis por imporem períodos de resfriamentos holocênicos, como o Dark Age Cold Period entre 1.500 e 1.050 anos A.P. (BLACKFORD; CHAMBERS, 1991; HELAMA; JONES; BRIFFA, 2017) e Little Ice Age por volta de 450 a 150 anos A.P (THOMPSON et al., 1986; GRAHAM et al., 2011).

A partir destas premissas, esta pesquisa objetiva evidenciar cronologicamente, a evolução de algumas bases teóricas-metodológicas responsáveis pela identificação de eventos paleoclimáticos, vinculados aos conceitos de mudanças, oscilações e pulsações climáticas, detalhados de maneira inédita nesta introdução.

\section{Metodologia}

Trata-se de revisões bibliográficas e reflexões teóricas sobre eventos paleoclimáticos de intensidades e abrangências temporais distintas. A análise foi conduzida de modo a evidenciar cronologicamente a evolução de algumas bases teóricas/metodológicas para identificação das mudanças, oscilações e pulsações climáticas. Tornase importante frisar que a grande maioria dos artigos abordados, também são provenientes de revisões teóricas que objetivaram traçar tendências a partir da correção e sobreposição de dados geocronológicos, vinculados a distintos proxies obtidos por numerosas pesquisas internacionais.

Inicialmente, foram destacadas as primeiras identificações de eventos glaciais e interglaciais (mudanças climáticas), abordando brevemente antigas nomenclaturas e técnicas de identificação pautadas em datações relativas, mediante estudos estratigráficos de depósitos correlacionados a transporte glacial (drift e till).

Posteriormente, foram promovidas discussões sobre a revolução dos isótopos cosmogênicos inerentes às alterações do sistema oceano-atmosfera, responsáveis pelo aperfeiçoamento do reconhecimento das mudanças climáticas e primeiras identificações de oscilações climáticas entre máximos glaciais e optimum climáticos. Trata-se especificamente dos estudos das razões de isótopos de oxigênio $\left({ }^{16} \mathrm{O},{ }^{18} \mathrm{O}\right)$ em foraminíferos pelágicos e bentônicos, dispostos em amostras intactas de sedimentos extraídos do leito do oceano. Neste ínterim, também foi abordado o sentido das novas nomenclaturas desenvolvidas por pesquisas mundialmente aceitas, provenientes da literatura paleoclimática internacional.

Finalmente, foram abordadas discussões teóricas que elucidaram subsídios metodológicos das Geociências para identificação de eventos climáticos de curta duração, ocorridos em escala de tempo recente da natureza (Pleistoceno Superior e Holoceno) envolvendo a mensuração de fenômenos vinculados à insolação solar, paleoprecipitações, liberação de sulfato em função de atividades vulcânicas, alteração da temperatura da superfície do mar e da circulação termohalina. 
Para tanto, foram evidenciadas pesquisas que empregaram diferentes métodos de datação $\left(\mathrm{U}-\mathrm{Th}, \delta^{13} \mathrm{C}, \delta^{18} \mathrm{O}\right.$, $\delta{ }^{15} \mathrm{~N},{ }^{87} \mathrm{Sr} /{ }^{86} \mathrm{Sr},{ }^{210} \mathrm{~Pb},{ }^{14} \mathrm{C}$, Be-10, Optically Stimulated Luminescence - OSL, Infrared Stimulated Luminescence - IRSL e Blue Light Stimulated Luminescence - BLSL) em distintos registros vinculados à espeleotemas de cavernas, beachrocks, entalhes de marés, quironomídeos, assembleias de diatomáceas, corais, anéis de árvore, Glicerol Dialquil Glicerol Tetraéteres (GDGTs), Hyrax de Rocha (Procavia capensis), núcleo de gelo, pólen, esporos, macrofósseis, carvão micro/macroscópico, espículas de esponjas, fitólitos e estratigráficos atrelados a depósitos de lago, turfa, loess, deltas fluviais, superfícies de aplainamento, estuários, manguezais, terraços fluviais e glaciares (morainas).

As discussões sobre os pulsos climáticos foram estruturadas de modo a evidenciar pesquisas que elucidaram tendências paleoclimáticas continentais e/ou regionais. Para isso, foram redigidos subitens que abordaram a variabilidade paleoclimática durante o Pleistoceno Superior e Holoceno na América do Norte, América Central, América do Sul (maior enfoque), Europa, África, Antártica, Ásia e Oceania, encerrando com um panorama construído a partir de pesquisas que identificaram ciclos de resfriamentos globais. A referida estruturação objetivou evidenciar que os pulsos climáticos holocênicos não ocorreram de modo sincronizado ao longo de todo globo terrestre, possuindo ritmos e intensidades diferentes, que variaram em função das distintas especificidades dos sistemas ambientais. Principalmente, relacionadas às variações altitudinais (orogênese), latitudinais e longitudinais (padrões de circulações atmosféricas das células de Hadley, Ferrel, Polar e Walker).

\section{Primeiras identificações de eventos glaciais e interglaciais: mudanças climáticas}

Penck e Brückner (1909) foram responsáveis por identificar pioneiramente, mediante datações relativas, quatro períodos glaciais nos Alpes durante o Quaternário, nomeados com base em rios da Bavária: Estádio Glacial Würm, Riss, Mindel e Günz, alternados por períodos interglaciais denominados respectivamente de estádios Riss/Würm, Mindel/Riss e Günz/Mindel.

Tais glaciações, impulsionadas por mudanças climáticas, foram identificadas mediante estudos estratigráficos de depósitos correlacionados a transporte glacial (drift e till). Os depósitos de till localizam-se em porções inferiores de montanhas sob influências glaciais, constituem sedimentos e fragmentos de rochas provenientes de intemperismo físico por congelamento, alojados mediante derretimento de geleiras (BELL, 2002; JOHNSON, 1986). Enquanto os depósitos de drift situam-se nos fundos de vales em função do retrabalhamento promulgado pela ação da água do degelo, depositados em lagos e rios (Figura 1) (STOKER et al., 1998).

Penck e Brückner (1909) também notaram que as camadas de till eram intercaladas por estratificações de turfeiras compostas por fragmentos vegetais, representativas de fases associadas ao recuo das geleiras e melhoria climática (interestadiais). Deste modo, os autores estabeleceram estádios glaciais e interglaciais quaternários, representados por avanços (till) e recuos das geleiras (turfeiras). Estes conhecimentos apresentaram-se fundamentais para o início da compreensão das transgressões e regressões marinhas ao longo do Quaternário. 


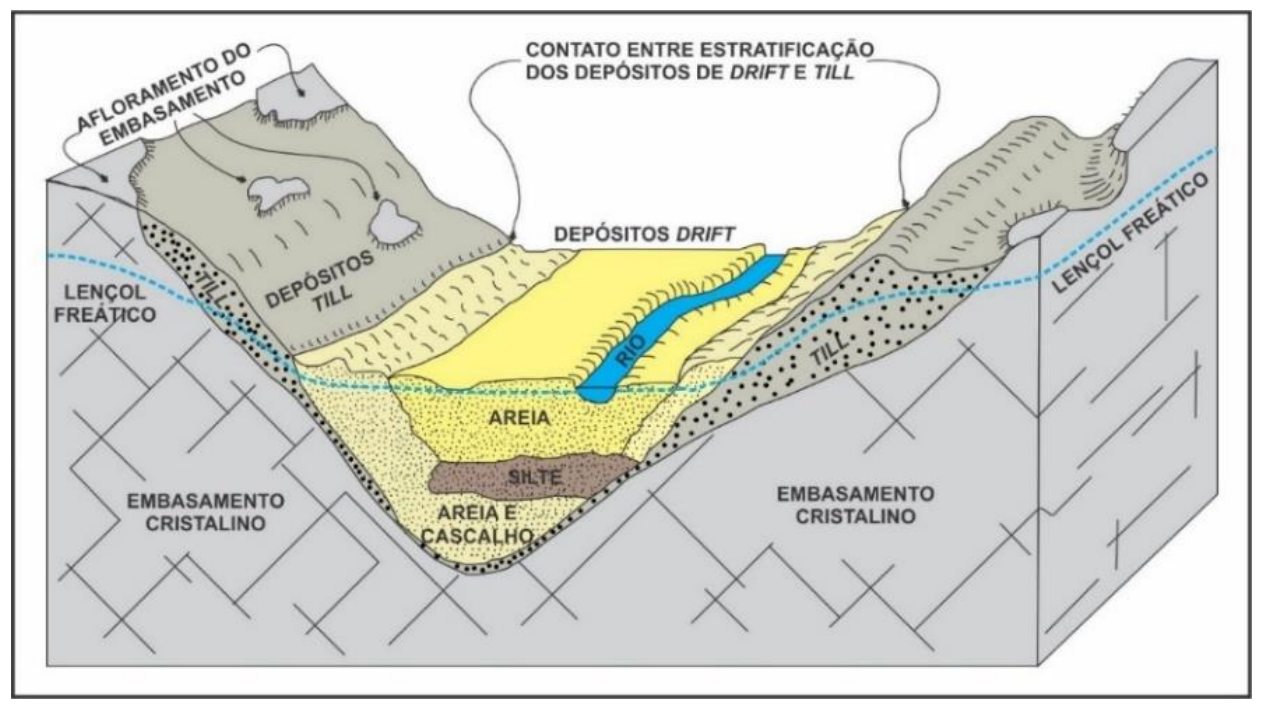

Figura 1. Seção idealizada evidenciando as relações espaciais entre a estratificação de depósitos de till, drift e embasamento cristalino.

Fonte: Adaptado e traduzido de Connecticut Department of Energy and Environmental Protection (2021).

Posteriormente, Eberl (1930) e Schaefer (1953) identificaram camadas de till mais antigas que as constatadas por Penck e Brückner (1909), associando-as com outras glaciações pleistocênicas, denominadas de estádios glaciais Danúbio e Bíber (SUGUIO, 2001).

\section{Revolução dos isótopos cosmogênicos: aperfeiçoamento da identificação das mudanças e oscilações climáticas}

Frisa-se que as nomenclaturas definidas por Penck e Brückner (1909), Eberl (1930) e Schaefer (1953), para determinação de episódios glaciais e interglaciais, eram comumente utilizadas até metade do século XX e atualmente encontram-se ultrapassadas. Foram substituídas por novas nomenclaturas, definidas por pesquisas mundialmente aceitas, publicadas em periódicos científicos internacionais, baseadas em isótopos de oxigênio (EMILIANI, 1955; SHACKLETON, 1969; BERGER; WEFER, 2003; LISIECKI; RAYMO, 2005; RAILSBACK, 2015; RAILSBACK et al., 2015a; RAILSBACK et al., 2015b).

O advento de modernas técnicas de datações, especificamente estudos das razões de isótopos de oxigênio $\left({ }^{18} \mathrm{O} /{ }^{16} \mathrm{O}\right)$ em foraminíferos bentônicos, dispostos em amostras intactas de sedimentos extraídos do leito do oceano, revelaram padrões consistentes em relação às mudanças no sistema oceano-atmosfera ao longo do tempo. Tais alterações estão intrinsicamente associadas a períodos glaciais/interglaciais e transgressões/regressões marinhas quaternárias (RAILSBACK et al., 2015a).

Resumidamente, evaporação e condensação são dois processos que mais influenciam a proporção de oxigênio pesado $\left({ }^{18} \mathrm{O}\right)$ e oxigênio leve $\left({ }^{16} \mathrm{O}\right)$ nos oceanos. Em períodos interglaciais como o atual, moléculas de água do mar contendo oxigênio leve evaporam relativamente mais rápido do que moléculas de água contendo um átomo de oxigênio pesado, enriquecendo à atmosfera (nuvens e precipitações) com ${ }^{16} \mathrm{O}$. Após ocorrência das precipitações em regiões continentais, moléculas de ${ }^{16} \mathrm{O}$ retornam rapidamente aos oceanos pelos rios, em função da regularização da capacidade hídrica proporcionada por climas mais úmidos. Nesta dinâmica o balanço entre ${ }^{18} \mathrm{O}$ e ${ }^{16} \mathrm{O}$ nas águas oceânicas é mantido.

Em oposição, em períodos glaciais, moléculas de ${ }^{16} \mathrm{O}$ evaporadas não retornam rapidamente ao oceano, grande parte se move em direção aos polos, as quais eventualmente se condensam e caem como neve nas camadas de gelo, onde permanecem. A diminuição da capacidade hídrica continental em função de clima mais seco também 
contribui para este processo. Nestes ambientes glaciais, a água que permanece no oceano desenvolve concentração cada vez maior ${ }^{18} \mathrm{O}$ em comparação com o padrão universal.

Deste modo, a maior disposição de isótopos de ${ }^{18} \mathrm{O}$ na composição de conchas carbonatadas e calcificadas de foraminíferos bentônicos, fossilizados em sedimentos de fundo oceânico, pode ser associada a períodos glaciais, temperaturas mais frias da água oceânica e movimentos eustáticos regressivos. De maneira oposta, a condição de maior balanço de isótopos ${ }^{18} \mathrm{O}$ e ${ }^{16} \mathrm{O}$ nas conchas, oferecem subsídios para associação com períodos interglaciais, temperaturas mais elevadas da água oceânica e movimentos eustáticos transgressivos.

Nesta dinâmica, Emiliani (1955), em estudo clássico e pioneiro, envolvendo dados isotópicos de oxigênio de foraminíferos bentônicos e pelágicos situados em águas profundas do Atlântico, Caribe e Pacífico, constatou que as temperaturas de águas superficiais no Atlântico Equatorial e Caribe sofreram oscilações periódicas durante o Pleistoceno, com amplitude de cerca de $6^{\circ} \mathrm{C}$. O autor identificou sete ciclos completos de temperatura mediante núcleos caribenhos e cerca de quinze ciclos por meio de núcleos do Pacífico.

Dentre estes ciclos, destaca-se o aumento contínuo de temperatura entre 16.500 e 6.000 anos A.P., sendo associado por Emiliani (1955), ao "Climatic Optimum" holocênico, sucedido por pequena diminuição de temperatura até os dias atuais. A identificação temporal deste evento (MIS1) apresentou-se determinante para reconstituições geocronológicas de relevos costeiros na passagem do Pleistoceno para o Holoceno. Por fim, Emiliani (1955) também projetou (mediante extensão da curva de insolação em direção ao futuro) que um mínimo de insolação poderia ser esperado em cerca de 10.000 anos, impondo condições favoráveis para início de nova glaciação e consequente regressão marinha.

A partir deste momento, mudanças climáticas, estádios glaciais/interglaciais e movimentos eustáticos regressivos/transgressivos começaram a ser designados como estágios numerados, conhecidos mundialmente como "estágios isotópicos marinhos" ou "marine isotope stages (MIS)", substituindo antigas denominações glaciais e interglaciais atribuídas por Penck e Brückner (1909), Eberl (1930) e Schaefer (1953).

Mediante aperfeiçoamento e desenvolvimento metodológico por meio de uma série de correções, pesquisas envolvendo isótopos de oxigênio se aprofundaram e adquiriram níveis mais detalhados sobre os fenômenos observados. Nesta perspectiva, Shackleton (1969) iniciou à subdivisão dos estágios identificados pioneiramente por Emiliani (1955) em subestágios representados por letras.

A pesquisa de Shackleton (1969) abordou especificamente à subdivisão do MIS5, vinculado ao penúltimo interglacial ( 120.000 anos A.P.) e regressão marinha subsequente. A partir dos resultados, o autor determinou novos subestágios de isótopos marinhos classificados como MIS5e, MIS5d, MIS5c, MIS5b, MIS5a. Os quatro últimos podem ser correlacionados ao conceito de oscilações climáticas em razão de: (i) constituírem-se como eventos climáticos de média duração que ocorreram no Pleistoceno; (ii) estarem situados temporalmente entre picos extremos de estágios glaciais e interglaciais (MIS2 e MIS5e) bem definidos (mudanças climáticas); e, (iii) serem responsáveis pela interrupção de contínuos descensos do nível relativo do mar até máximos glaciais (MIS5c e MIS5a).

Salienta-se que as conclusões de Shackleton (1969) tiveram importante influência na teoria das glaciações pleistocênicas e, em virtude disso, outras pesquisas buscaram novas subdivisões para ciclos climáticos pleistocênicos identificados preliminarmente por Emiliani (1955). Destacam-se estudos de Ninkovitch e Shackleton (1975), Pisias et al. (1984), Prell, Hays e Boden (1984), Martinson et al. (1987), Bussell e Pillans (1992), Tzedakis et al. (1997), Wu et al. (2004), Lisieck e Raymo (2005), Ashton et al. (2008), Wang et al. (2008), Westaway (2010) e Tzedakis et al. (2012).

Outra pesquisa que deve ser destacada, pela importância e influência em escala mundial, com relação às reconstruções paleoclimáticas e identificação de estádios glaciais/interglaciais, refere-se ao estudo de Lisieck e Revista Brasileira de Geomorfologia. 2021, v. 22, n. 4; (Out-Dez) DOI: 10.20502/rbg.v22i4.1895 
Raymo (2005). As autoras realizaram trabalho inédito ao apresentarem a primeira pilha bentônica de ${ }^{18} \mathrm{O}$ para se estender além de 850.000 anos A.P., já definidos pela pesquisa de Emiliani (1955). Para isso, utilizaram qualidade de sinal aprimorada pelos constantes avanços tecnológicos intrínsecos à metodologia em registros ${ }^{18} \mathrm{O}$ bentônicos de 57 locais distribuídos globalmente (oceanos Atlântico, Índico e Pacífico), alinhados por algoritmo de correlação gráfica automatizado.

Deste modo, Lisieck e Raymo (2005) conseguiram remontar ciclos climáticos que ocorreram em 5.3 milhões de anos A.P., oferecendo novos conhecimentos, antes inexplorados por pesquisadores paleoclimáticos. Com isso, as autoras determinaram mais 24 novos estágios de isótopos marinhos no início do Plioceno, exibindo coerência significativa com insolação na banda de obliquidade ao longo de 5.3 milhões de anos A.P.

As publicações das pesquisas mencionadas até o momento, acarretaram a disseminação de várias nomenclaturas divergentes e conflitantes, atribuídas aos ciclos paleoclimáticos identificados (designações letradas, numéricas, decimais), não havendo até então uma padronização adequada aos estágios e subestágios isotópicos marinhos, que começaram a ser identificados a partir do estudo de 1955 realizado por Emiliani.

Neste cenário, insere-se a relevância da pesquisa de Railsback et al. (2015a), que realizou um exame cuidadoso da literatura isotópica marinha internacional e propôs um esquema taxonômico completo e otimizado de subestações isotópicas marinhas composta por letras, abrangendo série temporal de 1 milhão de anos A.P. (MIS1 a MIS29). Tal esquema se apresenta como o mais adotado e referenciado atualmente (Figura 2).

A padronização de Railsback et al. (2015a) preconizou que eventos marinhos transgressivos, correlacionados ao aumento de temperatura e diminuição do volume global de gelo, fossem representados por números ímpares. Enquanto movimentos eustáticos regressivos, associados à diminuição de temperatura e elevação do volume global de gelo, fossem descritos por números pares. Assim, nomenclaturas utilizadas para referenciar máximos glaciais também se associam a números pares, enquanto optimum climáticos a números ímpares (Figura 2).

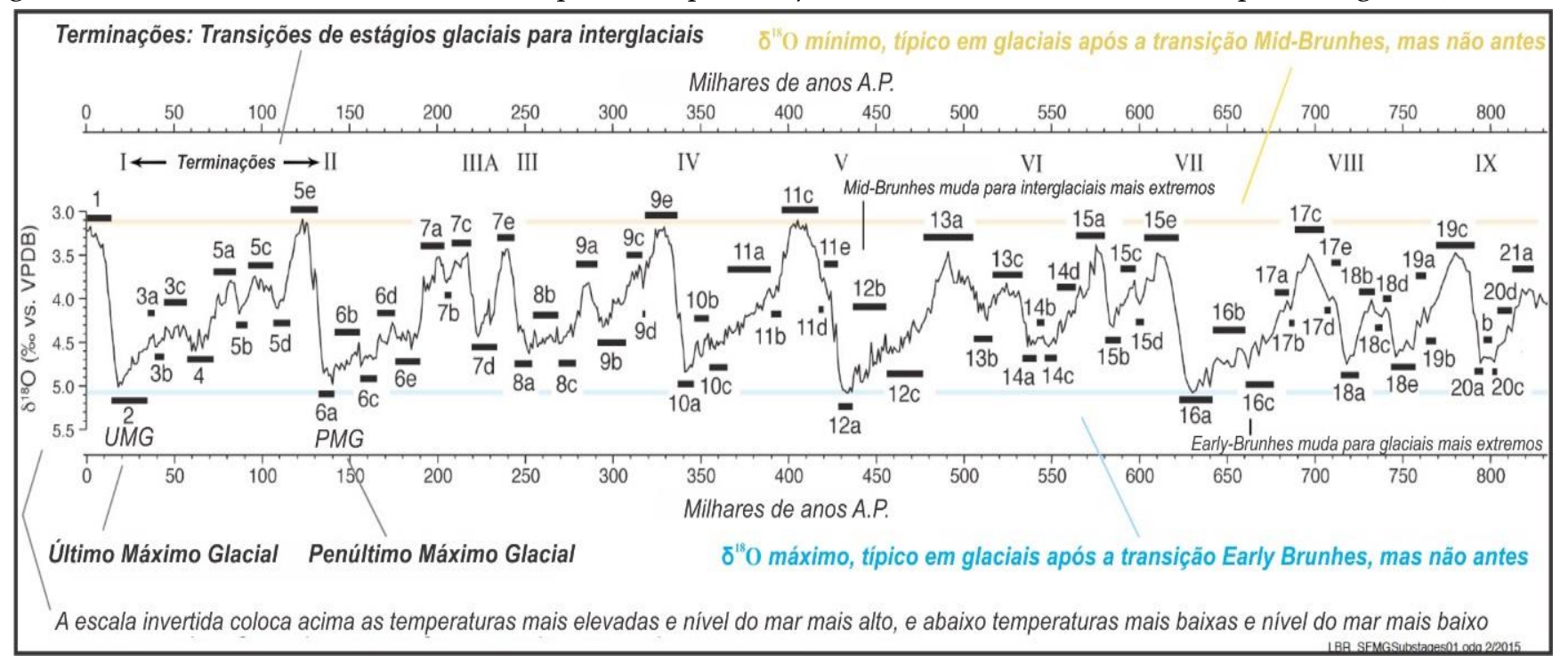

Figura 2. Estágios Isotópicos Marinhos (1 a 21a).

Fonte: Adaptado e traduzido de Railsback (2015, p.1).

Tais estudos, citados até o momento, envolvendo análises isotópicas de oxigênio, foram determinantes sobretudo, para identificação de movimentos eustáticos regressivos que se prolongaram abaixo do atual nível relativo do mar, suscitados por mudanças e oscilações climáticas inerentes aos estádios glaciais. 


\section{Contribuições das geociências para identificação de eventos climáticos de curta duração: pulsos climáticos}

Neste momento, cabe evidenciar alguns eventos climáticos de curta duração (ciclos máximos de 2.000 anos), ocorridos em escala de tempo recente da natureza (Pleistoceno Superior e Holoceno), associados ao conceito de pulsações climáticas holocênicas. Algumas oscilações climáticas inevitavelmente também foram abordadas, uma vez que estas tendências de média duração contextualizam e influenciam à ocorrência dos pulsos.

Desta maneira, as discussões e reflexões teóricas dispostas a seguir, foram estruturadas de modo a evidenciar pesquisas recentes que identificaram pulsações em distintas regiões do globo terrestre, a saber: América do Norte, América Central, América do Sul, Antártica, África, Ásia, Oceania e Europa. Finalmente, também será destacado o artigo referência, desenvolvido por Wanner et al. (2011), responsável pela identificação de seis eventos de resfriamentos globais holocênicos.

A referida estruturação objetivou evidenciar que os pulsos climáticos holocênicos não ocorreram de modo sincronizado ao longo de todo globo terrestre, possuindo ritmos e intensidades diferentes, que variam em função das distintas especificidades dos sistemas ambientais, porém atuam mediante respostas impulsionadas por tendências de fenômenos climáticos globais (ciclos de resfriamento).

\subsection{Pulsos climáticos identificados na América do Norte}

Iniciando pela América do Norte, optou-se por destacar estudos em duas regiões dos Estados Unidos da América que atualmente pertencem a climas totalmente distintos (subtropical e subpolar), no Texas (WONG; BANNER; MUSGROVE, 2015) e Alasca (TINNER et al., 2015).

Em um primeiro momento, Wong, Banner e Musgrove (2015) sintetizaram dados paleoclimáticos de proxies e simulações climáticas provenientes de outras publicações, objetivando fornecer uma visão geral da variabilidade climática no Texas durante o Holoceno. Em seguida, os autores propuseram mediante uma reconstrução de espeleotema de uma caverna no centro do Texas, uma nova simulação da variabilidade climática abrangendo o Holoceno (7.000 anos A.P.), indicando condições de umidade variáveis neste período a partir da mudança nos valores dos isótopos de ${ }^{18} \mathrm{O}$ e ${ }^{13} \mathrm{C}$. Segundo os autores, tais alterações refletem mudanças na composição do ecossistema que recobre a caverna, as quais podem ter sido responsáveis pela redução observada na taxa de crescimento do espeleotema durante o período estudado. Com base nos resultados adquiridos, Wong, Banner e Musgrove (2015) determinaram uma tendência de aquecimento / aridez no Holoceno Inferior ao Holoceno Médio, uma breve mudança das condições de quente / seco na transição do Holoceno Médio ao Holoceno Superior e um intervalo seco no Holoceno Superior.

Neste viés, Tinner et al. (2015) analisaram sedimentos com idades entre 4.100 e 1.800 anos A.P. no lago Grizzly, centro-sul do Alasca, para um conjunto de indicadores complementares de mudanças climáticas e ecológicas pretéritas (pólen, esporos, macrofósseis, carvão micro e macroscópico, quironomídeos e diatomáceas).

Os pólens, esporos e macrofósseis foram utilizados para inferir à dinâmica da vegetação em função das alterações suscitadas por pulsos climáticos; os fragmentos de carvões para reconstruir atividades anteriores a incêndios; os quironomídeos para derivar quantitativamente a paleotemperatura média do ar e as diatomáceas para interpretar antigos níveis dos lagos a partir de correlações entre precipitação / evaporação.

A partir da correlação das idades obtidas nestes indicadores (datações por radiocarbono), Tinner et al. (2015) determinaram à ocorrência de pulsos climáticos responsáveis por impor: (i) resfriamento climático na ordem de $2^{\circ} \mathrm{C}$ entre 2.800 a 2.500 anos A.P., causando o colapso das florestas e a expansão da vegetação arbustiva na área do lago Grizzly; (ii) aumento das aberturas florestais por volta de 3.300-3.100 e 2.300-2500 anos A.P., resultante de um resfriamento a partir da diminuição da irradiância solar (inferências realizadas a partir das diatomáceas); (iii) queda de 5m do nível da água do lago entre 3.200 e 1.800 anos A.P., sugerindo condições secas e diminuição da Revista Brasileira de Geomorfologia. 2021, v. 22, n. 4; (Out-Dez) DOI: 10.20502/rbg.v22i4.1895 
umidade durante o período; e, (iv) diminuição da cobertura vegetal e erosão do solo entre 3.300 e 3.100, 2.800 e 2.500, 2.300 e 2100 anos A.P., inferidas a partir do aumento dos valores de $\mathrm{Al}, \mathrm{K}$, $\mathrm{Si}$, Ti e Ca, intensificados quando a irradiância solar é baixa.

A partir destes resultados, Tinner et al. (2015) puderam concluir que os pulsos climáticos observados no Holoceno Superior, marcaram o estabelecimento de modernas florestas boreais no Alasca, onde expandiram-se formações vegetais adaptadas ao clima frio. Assim, os autores sugeriram que a Picea glauca (abeto branco) foi dominante durante condições climáticas quente-úmidas, enquanto à Picea mariana (abeto preto) prevaleceu em condições de frio/seco e quente/seco (regimes de incêndio).

\subsection{Pulsos climáticos identificados na América Central}

Pulsos climáticos holocênicos também foram identificados na América Central por Wu, Porinchu e Horn (2019), a partir de um esforço de revisão bibliográfica em conjunto com análise de um novo dado proxie. Os autores objetivaram realizar reconstruções de temperatura baseadas em datações por ${ }^{14} \mathrm{C}$ em quiromídeos, posicionados em sedimentos de lago glacial, situado na encosta atlântica da cordilheira Talamanca (Lago Morrenas) e outro na encosta do Pacífico (Laguna Zoncho), ambos localizados na Costa Rica.

Os resultados obtidos indicaram nível mais baixo da água e diminuição da umidade efetiva, dinâmica correlacionada por Wu, Porinchu e Horn (2019), a pulso climático responsável por impor na América Central início de resfriamento e seca severa entre 1.410 e 790 anos A.P. e/ou 610 e 1.230 E.C. (era comum, conforme utilizado pelos autores), precedido por um clima relativamente mais quente e úmido entre 1.720 e 1.410 anos A.P e/ou 300 e 610 E.C. Importante notar que este episódio de resfriamento identificado por Wu, Porinchu e Horn (2019), correlaciona-se com a fase mais fria determinada por Tinner et al. (2015) a partir de registros no Lago Grizzly (Alaska).

Nesta perspectiva, Wu, Porinchu e Horn (2019) realizaram a sobreposição da cronologia de seus dados e interpretações com diversos registros paleoclimáticos datados entre 1.420-820 anos A.P. e/ou 600-1.200 C.E., obtidos por diversas pesquisas realizadas em países da América Central em Belize, Guatemala, Nicarágua, Costa Rica, Panamá e República Dominicana. Quando correlacionados, os resultados indicaram que a maioria dos locais de estudo na América Central e América do Norte (México), experimentaram um intervalo de seca entre 1.270-820 anos A.P. e/ou 750-1.200 C.E. Sobrepondo-se a dois episódios climáticos conhecidos, a anomalia climática medieval (Medieval Climate Anomaly - MCA) (1.070-770 anos A.P. e/ou 950-1.250 C.E) e seca clássica terminal Maya (Maya Terminal Classic Drought - TCD) (1.250-920 anos A.P. e/ou 770-1.100 C.E).

\subsection{Pulsos climáticos identificados na América do Sul}

Neste momento, apresenta-se e discute-se resultados de recentes descobertas científicas publicadas entre os anos de 2002 e 2020, responsáveis por identificarem tendências paleoclimáticas durante o Pleistoceno Superior e Holoceno na América do Sul. Assim, foram envolvidos na revisão, variados sistemas ambientais espacializados ao longo da extensão continental, constituindo mosaico de análise atrelado aos seis biomas brasileiros (amazônia, mata atlântica, cerrado, pantanal, pampas e caatinga), ambientes orogenéticos (cordilheira dos Andes tropical, Andes Centrais adjacentes ao deserto do Atacama e sul dos Andes) e ambientes patagônicos (terra do fogo no extremo sul do continente, patagônia andina ocidental e patagônia pampeana/estépica oriental).

Frisa-se que as discussões inerentes a este tópico se tornaram inevitavelmente mais extensas e detalhadas, pois objetivou-se atender ao maior interesse do público brasileiro e dos leitores da Revista Brasileira de Geomorfologia, uma vez que a maioria dos trabalhos publicados no periódico abordam superfícies geomorfológicas situadas no território brasileiro. Assim, compreender como o paleoclima se comportou nos últimos milhares de anos, pode 
auxiliar e contribuir com diversas interpretações genéticas evolutivas de relevos esculturais que, posteriormente, podem integrar futuras publicações no periódico em questão.

Em relação ao Brasil, estrategicamente, organizou-se a revisão por meio de quadros sínteses (Quadros 1, 2, 3, 4, 5 e 6), tentando englobar a maior espacialidade possível dos registros perante a extensão dos seis biomas brasileiros e, compreender as influências das condições atmosféricas pretéritas frente às respostas e alterações observadas nos sistemas ambientais do presente.

Nesse sentido, o texto foi estruturado de modo a destacar (sempre no início de cada tópico), os principais sistemas meteorológicos que atualmente causam precipitação em cada bioma, seguido das principais tendências paleoclimáticas identificadas no Pleistoceno Superior (UMG e deglaciação), Holoceno Inferior, Holoceno Médio e Holoceno Superior. Salienta-se que ao finalizar as reflexões presentes em cada um dos tópicos (biomas), também buscou-se destacar as forçantes climáticas responsáveis por imporem os padrões observados.

Por meio dos quadros sínteses, observa-se que as principais e mais recentes reconstruções da história dos paleoclimas do Brasil, se apoiam em estudos das razões de isótopos de oxigênio em espeleotemas de cavernas e palinológicos, bioquímicos e físicos em sequências de depósitos lacustres $\left({ }^{14} \mathrm{C}\right)$.

O princípio do método aplicado em espeleotemas cársticos, consiste em analisar à composição dos isótopos de oxigênio no carbonato de cálcio depositado durante o desenvolvimento de tais formas. Segue o mesmo fundamento interpretativo descrito anteriormente no item 4, relativo aos registros isotópicos em foraminíferos bentônicos do fundo oceânico e núcleo de gelo. Todavia, as aplicações em estalagmites e estalactites buscam revelar padrões de paleoprecipitações, ao invés da salinidade e paleotemperaturas da água oceânica e do ar $\left(\delta^{18} \mathrm{O} / \delta^{16} \mathrm{O}\right.$ em foraminíferos e núcleos de gelo).

Resumidamente, evaporação e condensação também são os dois processos que mais influenciam a proporção de oxigênio pesado $\left({ }^{18} \mathrm{O}\right)$ e oxigênio leve $\left({ }^{16} \mathrm{O}\right)$ nos espeleotemas cársticos. Moléculas de água do mar contendo oxigênio leve $\left({ }^{16} \mathrm{O}\right)$ evaporam relativamente mais rápido do que moléculas de água contendo um átomo de oxigênio pesado $\left({ }^{18} \mathrm{O}\right)$, enriquecendo à atmosfera (nuvens e precipitações) com ${ }^{16} \mathrm{O}$. Assim, teoricamente, quando começa a chover no interior continental, as moléculas de água com ${ }^{18} \mathrm{O}$ precipitam primeiro por serem mais pesadas, enquanto a umidade restante, condensada, fica cada vez mais enriquecida de ${ }^{16} \mathrm{O}$. Nesta dinâmica, as precipitações enriquecidas de ${ }^{18} \mathrm{O}$ atingem o teto da caverna, penetram no solo e carregam o carbonato de cálcio para o interior cárstico, desenvolvendo as estalactites no teto e estalagmites no piso.

Nesta perspectiva, a partir da razão encontrada entre ${ }^{18} \mathrm{O} /{ }^{16} \mathrm{O}$, os pesquisadores também conseguem inferir se o clima da época era mais seco (mais $\delta^{18} \mathrm{O}$ ) ou mais úmido (menos $\delta^{18} \mathrm{O}$ ) durante a deposição das camadas de calcário. Os autores que trabalham com este método consideram que em regiões onde chove muito, como na amazônia, a tendência é encontrar sequência de camadas de carbonato de cálcio com quantidade relativamente menor de ${ }^{18} \mathrm{O}$ e maior de ${ }^{16} \mathrm{O}$. Inversamente, em regiões de clima seco como na caatinga, a pouca chuva que cai tem relativamente mais ${ }^{18} \mathrm{O}$.

Tais feições, quando datadas por urânio-238/tório-230, também se apresentam responsáveis por indicarem a quantidade e a variabilidade temporal da precipitação tropical, por meio de correlações com as taxas de crescimento (gotejar lento ou rápido com carbonato de cálcio dissolvido). Deste modo, quanto maior for a distância entre os pontos datados no espeleotema e menor for a diferença entre as idades, mais rápido o crescimento se caracterizou (precipitações com maior frequência e intensidade). Em oposição, quanto menor for a distância entre os pontos datados e, maior for a diferença entre as idades, mais lento se caracterizou o crescimento dos espeleotemas (precipitações com menor frequência e intensidade). 


\subsubsection{Amazônia}

No quadro 1 foram abordados registros no oeste da amazônia (APAÉSTEGUI et al., 2014); amazônia central (SANT'ANNA et al., 2017); sul da amazônia (FONTES et al., 2017) e leste da amazônia (AZEVEDO et al., 2019; WANG et al., 2017). Ressalta-se a dificuldade de encontrar publicações com registros no núcleo e norte amazônico, sendo localizados somente trabalhos atrelados a ecótonos e faixas de transição entre biomas (RULL; MONTOYA, 2017; ALIZADEH; COHEN; BEHLING, 2019; MONTOYA et al., 2019). Contudo, como tais análises poderiam não expressar fielmente as transformações dos sistemas ambientais amazônicos, não foram inseridas no quadro síntese (Quadro 1).

Reconstruir a história paleohidroclimática amazônica não é uma tarefa fácil, em razão da dificuldade de locomoção no território e sobretudo por constituir um dos principais centros de convecção atmosférica do planeta. Os resultados das pesquisas mencionadas no parágrafo anterior, convergem para uma conexão e dependência das atividades do sistema de monções sul-americano (SMSA) com as profundas convecções promovidas pela zona de convergência intertropical (ZCIT), caracterizada por ser uma banda de baixa pressão em setores de convergência dos ventos alísios, em faixas equatoriais de máxima temperatura da superfície do oceano Atlântico.

Durante o verão, a maior irradiância solar suscita à elevação da temperatura da superfície do oceano na costa norte do continente, acarretando o aumento da evaporação e o suprimento de umidade para amazônia a partir da atuação dos ventos alísios, provocando profundas convecções promovidas pela ZCIT na região norte do Brasil. A variabilidade dos valores destas variáveis em curto, médio e longo prazo define as tendências paleoclimáticas da amazônia (APAÉSTEGUI et al., 2014; WANG et al., 2017).

De modo geral, a amazônia foi muito mais seca durante o último período glacial ( 45.000-17.800 anos A.P.). A temperatura da superfície do mar na faixa equatorial da ZCIT diminuiu cerca de $2-3^{\circ} \mathrm{C}$, ocasionando a redução no suprimento de umidade do oceano e presença de nuvens convectivas, fatores que impuseram um arrefecimento de $5^{\circ} \mathrm{C}$ na bacia amazônica. Estas circunstâncias acarretaram a diminuição dos valores de precipitação, volume de água nos canais, redução da cobertura da florestal amazônica e expansão para savana aberta (SANT'ANNA et al., 2017; WANG et al., 2017; FONTES et al., 2017).

Durante o Heinrich 1 (H1) e degelo pós-glacial, observou-se o aumento de 1/3 da concentração de $\mathrm{CO}_{2}$, temperaturas mais quentes, aumento nos níveis de precipitação amazônica e elevação dos volumes de água dos canais fluviais. A tendência de intensificação das condições de umidade continuou durante o Holoceno Inferior e Holoceno Médio, quando a floresta amazônica se tornou muito mais densa em comparação com a configuração moderna (SANT'ANNA et al., 2017; FONTES et al., 2017; WANG et al., 2017). 
Quadro 1. Tendências paleoclimáticas na amazônia ao longo do Pleistoceno Superior e Holoceno.

\begin{tabular}{|c|c|c|c|c|c|}
\hline Bioma & Localização da Região & Tipo de Registro & Método & Tendências paleoclimáticas (anos A.P.) & Referências \\
\hline \multirow{5}{*}{ 崩 } & $\begin{array}{l}\text { Oeste da Amazônia } \\
\text { Noroeste do Peru } \\
\text { Leste dos Andes }\end{array}$ & $\begin{array}{c}\text { Isotópico em } \\
\text { espeleotemas da } \\
\text { caverna Palestina } \\
\text { situada no alto da } \\
\text { bacia amazônica } \\
\left(5.92^{\circ} \mathrm{S}, 77.35^{\circ} \mathrm{W}\right)\end{array}$ & U-Th & 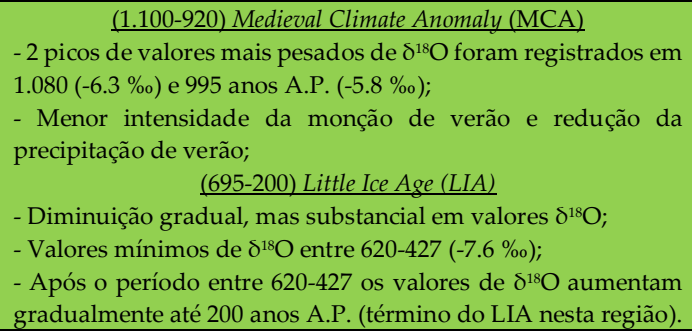 & $\begin{array}{l}\text { Apaéstegui et } \\
\text { al. (2014) }\end{array}$ \\
\hline & $\begin{array}{l}\text { Amazônia Central (AM) } \\
\text { Estado do Amazonas }\end{array}$ & $\begin{array}{l}\text { Depósitos fluviais e } \\
\text { lacustres da planície } \\
\text { aluvial central do Rio } \\
\text { Solimões-Amazonas }\end{array}$ & $\begin{array}{l}{ }^{14} \mathrm{C} \text { (AMS) } \\
\text { OSL/SAR }\end{array}$ & $\begin{array}{l}\text { 25.300 - } 17.700 \text { (UMG - rebaixamento do nível de base): } \\
\text { - Diminuição da precipitação e volume de água nos canais; } \\
\text { - Isostasia continental, formação de terraços fluviais; } \\
\text { - Deposição da planície de inundação pleistocênica foi } \\
\text { contemporânea ao intemperismo do terraço. } \\
\quad 11.500 \pm 1.500 \text { (UMG - MS1 - aumento do nível de base): } \\
\text { - Aumento da precipitação e volume de água nos canais; } \\
\text { - Ajuste isostático do continente, deposição de barras fluviais } \\
\text { laterais e formação de planície de inundação atual. }\end{array}$ & $\begin{array}{l}\text { Sant'Anna } \\
\text { et al. (2017) }\end{array}$ \\
\hline & $\begin{array}{l}\text { Sul da Amazônia (PA) } \\
\text { Sul do Estado do Pará }\end{array}$ & $\begin{array}{c}\text { Palinológico, } \\
\text { sedimentológico e } \\
\text { geoquímico orgânico } \\
\text { em sedimentos do } \\
\text { Lago do Saci (PA) } \\
\left(09^{\circ} 07^{\prime} \mathrm{S} / 56^{\circ} 16^{\prime} \mathrm{W}\right)\end{array}$ & $\begin{array}{c}{ }^{14} \mathrm{C} \text { (AMS) } \\
{ }^{15} \mathrm{~N} \\
{ }^{133} \mathrm{C}\end{array}$ & $\begin{array}{c}\text { Expansão para savana aberta e redução do lago } \\
\text { - } 35.000 \text { e } 18.200 \text { (clima mais seco/frio e eventos de fogo); } \\
\text { - } 18.200 \text { e } 9.200 \text { (condições secas e hiato de sedimentação); } \\
\text { - } 7.500 \text { e } 5.000 \text { (fase seca/redução da monção sul-americana). } \\
\text { Expansão para floresta tropical e alta producão lacustre } \\
\text { - 9.200-7.500 (condições mais quentes e úmidas / } \uparrow \text { do lago); } \\
\text { - } 5.000-1.800 \text { (retorno às condições mais úmidas / } \uparrow \text { do lago); } \\
\text { - 1.800-1.300 (diminuição da precipitação em clima úmido). }\end{array}$ & $\begin{array}{l}\text { Fontes et al. } \\
\text { (2017) }\end{array}$ \\
\hline & $\begin{array}{l}\text { Leste da Amazônia (PA) } \\
\text { Estado do Pará (PA) }\end{array}$ & $\begin{array}{l}\text { Palinológico em } \\
\text { sequência de } \\
\text { depósito lacustre do } \\
\text { Lago Arapujá (PA) } \\
\left(3^{\circ} 48^{\prime} \mathrm{S} / 52^{\circ} 40^{\prime} \mathrm{W}\right)\end{array}$ & ${ }^{14} \mathrm{C}$ (AMS) & $\begin{array}{l}\text { (1.095-870) Early Medieval Climate Anomaly } \\
\text { - As concentrações de palinomorfos arbóreos indicam } \\
\text { condições de forte período úmido (expansão da terra firme); } \\
\quad \text { (870-670) Late-Medieval Climate Anomaly } \\
\text { - As concentrações de palinomorfos arbóreos indicam } \\
\text { condições mais secas (expansão de gramíneas); } \\
\text { (670-570) Pré-LIA e Little Ice Age (570-170) } \\
\text { - As concentrações de palinomorfos arbóreos mantiveram } \\
\text { tendência decrescente, indicando condições menos úmidas do } \\
\text { que durante o Early-MCA. }\end{array}$ & $\begin{array}{l}\text { Azevedo et al. } \\
\quad(2019)\end{array}$ \\
\hline & $\begin{array}{l}\text { Leste da Amazônia (PA) } \\
\text { Estado do Pará (PA) }\end{array}$ & $\begin{array}{c}\text { Isotópico em } \\
\text { espeleotema da } \\
\text { Caverna Paraíso } \\
\left(04^{\circ} 04^{\prime} \mathrm{S} / 55^{\circ} 27^{\prime} \mathrm{W}\right)\end{array}$ & $\begin{array}{l}\delta^{18} \mathrm{O} \\
\mathrm{U}-\mathrm{Th}\end{array}$ & 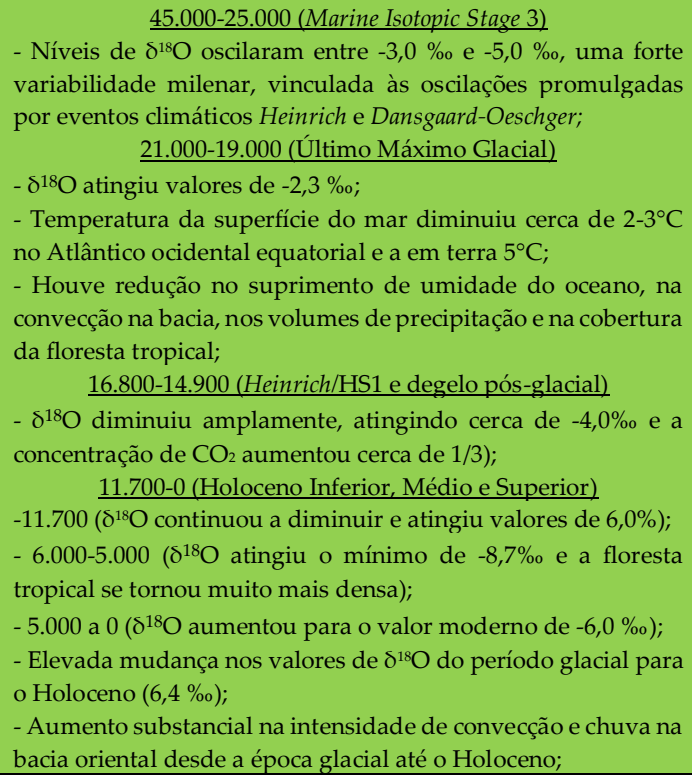 & $\begin{array}{l}\text { Wang et al. } \\
\text { (2017) }\end{array}$ \\
\hline
\end{tabular}

No decorrer da transição do Holoceno Médio para o Holoceno Superior, as condições de umidade diminuíram, atingindo os valores de precipitações atuais. Neste período, a Anomalia Climática Medieval foi marcada por menor intensidade da monção de verão e redução das precipitações. Enquanto a época da Pequena Idade do Gelo experimentou fase mais úmida que a atual, contrariando as evidências do hemisfério norte, onde 
muitos registros apontam para um clima mais frio e seco durante este evento (APAÉSTEGUI et al., 2014; SANT'ANNA et al., 2017; FONTES et al., 2017; AZEVEDO et al., 2019).

\subsubsection{Cerrado}

Em relação à extensão do bioma do cerrado (Quadro 2), foram abordados registros a oeste (NOVELLO et al., 2016); no cerrado central (WORTHAM et al., 2017; NOVELLO et al., 2018; CASSINO et al., 2020), no sudoeste do cerrado (NOVELLO et al., 2018) e norte do cerrado (AZEVEDO et al., 2019). Frisa-se que na discussão do quadro 2 priorizou-se a seleção de pesquisas que focaram no paleoclima do Holoceno. Contudo, reconstruções a partir do UMG podem ser observadas no estudo desenvolvido por Novello et al. (2017).

Os resultados das pesquisas mencionadas no parágrafo anterior, assim como na amazônia, também convergem para uma conexão e dependência das atividades do SMSA com as profundas convecções promovidas pela ZCIT. No entanto, nas regiões do cerrado, a variabilidade das atividades da Zona de Convergência do Atlântico Sul (ZCAS), apresenta-se como principal mecanismo perante a configuração dos padrões paleohidroclimáticos.

Torna-se válido destacar que a formação e a variabilidade da ZCAS são dependentes das atividades do SMSA associadas à ZCIT; da evapotranspiração da vegetação amazônica que devolve parte da água da chuva que cai sobre a floresta para atmosfera; da sucção dos ventos alísios que carregam umidade para oeste da bacia amazônica; da zona de convergência imposta pela barreira orográfica da Cordilheira dos Andes; da impulsão e instabilidade convectiva ocasionada pelo Jato de Baixo Nível Sul Americano (ventos muito fortes de baixa altitude que são canalizados para o sul pelos Andes orientais e planaltos brasileiros) e do sistema de alta pressão denominado de Alta da Bolívia (AB), caracterizada por intensa atividade convectiva que se estende por grande parte da América do Sul durante os meses de verão (MARENGO; DOUGLAS; DIAS, 2002).

A interação entre todos os mecanismos destacados no parágrafo anterior, propicia o desenvolvimento de uma faixa de nebulosidade orientada no sentido NW-SE, que se estende do sul da amazônia até o Atlântico sul central (ZCAS), escoando a umidade e irrigando o centro-oeste e sudeste brasileiro (cerrado, pantanal e mata atlântica). Principalmente durante a sazonalidade vinculada ao final da primavera e verão chuvoso.

De modo geral, os registros isotópicos provenientes do cerrado, diferentemente da amazônia, indicaram condições mais úmidas ao longo do Último Máximo Glacial (NOVELLO et al., 2017). Durante o início do H1, término do H1 e degelo pós-glacial, as atividades do SMSA se intensificaram, impondo condições ainda mais úmidas no cerrado brasileiro (NOVELLO et al., 2017). Contudo, esta tendência mais úmida não foi observada por algumas pesquisas que se utilizaram de proxies biológicos e palinológicos, onde as interpretações convergiram para condições mais secas ao longo do UMG (WHITNEY et al., 2011; FORNACE et al. 2016). Segundo Novello et al. (2017), isso pode significar que a vegetação da região pode não ter respondido rapidamente às mudanças na precipitação, mas, sim, as alterações na temperatura ou quantidade de $\mathrm{CO}_{2}$ na atmosfera.

Em contrapartida, durante o período Bølling-Allerød, transição Pleistoceno/Holoceno e Holoceno Inferior, o cinturão do SMSA mudou significativamente, impondo tendências que apontam para um clima relativamente seco, em razão da maior influência das massas de ar polares atingindo o centro do cerrado. Esta tendência mais seca foi interrompida por condições mais úmidas apenas durante o Younger Dryas (NOVELLO et al., 2017; AZEVEDO et al., 2019). 
Quadro 2. Tendências paleoclimáticas no cerrado ao longo do Pleistoceno Superior e Holoceno.

\begin{tabular}{|c|c|c|c|c|c|}
\hline Bioma & $\begin{array}{l}\text { Localização da } \\
\text { Região }\end{array}$ & Tipo de Registro & Método & Tendências paleoclimáticas (anos A.P.) & Referências \\
\hline \multirow{5}{*}{ 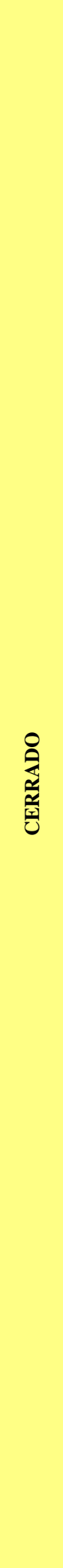 } & $\begin{array}{l}\text { Oeste do Cerrado } \\
\text { Estado do Mato } \\
\text { Grosso } \\
\text { Rosário Oeste (MT) }\end{array}$ & $\begin{array}{c}\text { Isotópico em } \\
\text { espeleotemas das } \\
\text { cavernas Curupira } \\
\text { e Pau d'Alho } \\
\left(15^{\circ} 12^{\prime} \mathrm{S} / 06^{\circ} 47^{\prime} \mathrm{W}\right) \\
\left(15^{\circ} 12^{\prime} \mathrm{S} / 56^{\circ} 48^{\prime} \mathrm{W}\right)\end{array}$ & $\begin{array}{l}\delta^{18} \mathrm{O} \\
\mathrm{U} / \mathrm{Th}\end{array}$ & $\begin{array}{l}\quad(1.120-920) \text { Medieval Climate Anomaly (MCA) } \\
\text { - } \delta^{18} \mathrm{O} \text { atingiu valores médios de }-5,71 \% \text { durante a MCA; } \\
\text { - As anomalias mais enriquecidas de } \delta^{18} \mathrm{O} \text { coincidem com as anomalias } \\
\text { negativas da irradiância solar; } \\
\text { - Enfraquecimento do sistema de monção; } \\
\text { - Clima mais seco quando comparado ao vigente no LIA; } \\
\qquad \frac{(420-200) \text { Little Ice Age (LIA) }}{\text { - } \delta^{18} \mathrm{O} \text { atingiu valores médios de }-6,57 \% \text { durante a LIA; }} \\
\text { - As anomalias mais negativas de } \delta^{18} \mathrm{O} \text { coincidem com as anomalias } \\
\text { positivas da irradiância solar; } \\
\text { - Fortalecimento do sistema de monção da América do Sul; } \\
\text { - Clima mais úmido quando comparado ao vigente no MCA. }\end{array}$ & $\begin{array}{l}\text { Novello et al. } \\
\text { (2016) }\end{array}$ \\
\hline & $\begin{array}{c}\text { Cerrado Central } \\
\text { Estado de Minas } \\
\text { Gerais } \\
\text { Cabeceira Grande } \\
\text { (MG) }\end{array}$ & $\begin{array}{c}\text { Isotópico em } \\
\text { espeleotema da } \\
\text { Caverna Tamboril } \\
\left(16^{\circ} \mathrm{S}, 47^{\circ} \mathrm{W}\right)\end{array}$ & $\begin{array}{c}{ }^{87} \mathrm{Sr} /{ }^{86} \mathrm{Sr} \\
\text { XRD } \\
\mathrm{U} / \mathrm{Th} \\
\delta^{18} \mathrm{O} \\
\delta_{13} \mathrm{C}\end{array}$ & $\begin{array}{l}\text { (2.000-0) Análises relativas aos } 2 \text { últimos milênios } \\
\text { - Valores de } \delta^{18} \mathrm{O} \text { oscilaram entre }-6,0 \% \text { e }-4,5 \% \text {, com raros momentos } \\
\text { atingindo valores baixos }(-7 \% \text { ); } \\
\text { - Os registros de } \delta^{18} \mathrm{O} \text { não exibiram tendência significativa no último } \\
\text { milênio, em contraste com muitos registros } \delta^{18} \mathrm{O} \text { na região das } \\
\text { monções, sugerindo a existência de mudanças divergentes nos } \\
\text { padrões climáticos dentro e fora da região central das monções, } \\
\text { influenciado pela ZCAS; } \\
\text { - As maiores contribuições de umidade proveniente da ZCAS diluíram } \\
\text { o sinal de monção herdado da dinâmica a montante (ausência de uma } \\
\text { tendência milenar); } \\
\text { - O aumento da insolação de verão no hemisfério sul é um fator } \\
\text { plausível para explicar a diminuição dos valores de } \delta^{18} \mathrm{O} \text { no último } \\
\text { milênio ( } \uparrow \text { da intensidade das monções). }\end{array}$ & $\begin{array}{c}\text { Wortham et al. } \\
\text { (2017) }\end{array}$ \\
\hline & $\begin{array}{c}\text { Sudoeste do Cerrado } \\
\text { Mato Grosso do Sul } \\
\text { Bonito (MS) } \\
\text { Cerrado Central } \\
\text { Estado de Goiás } \\
\text { São Domingos (GO) }\end{array}$ & $\begin{array}{l}\text { Isotópico em } \\
\text { espeleotemas da } \\
\text { Caverna } \\
\text { Jaraguá (MS) } \\
\left(21^{\circ} 05^{\prime} \mathrm{S} / 56^{\circ} 35^{\prime} \mathrm{W}\right) \\
\\
\text { Isotópico em } \\
\text { espeleotemas das } \\
\text { Cavernas } \\
\text { São Bernardo e } \\
\text { São Mateus }(\mathrm{GO}) \\
\left(13.81^{\circ} \mathrm{S} / 46.35^{\circ} \mathrm{W}\right)\end{array}$ & $\begin{array}{l}\text { XRD } \\
\mathrm{U} / \mathrm{Th} \\
\delta^{18} \mathrm{O}\end{array}$ & 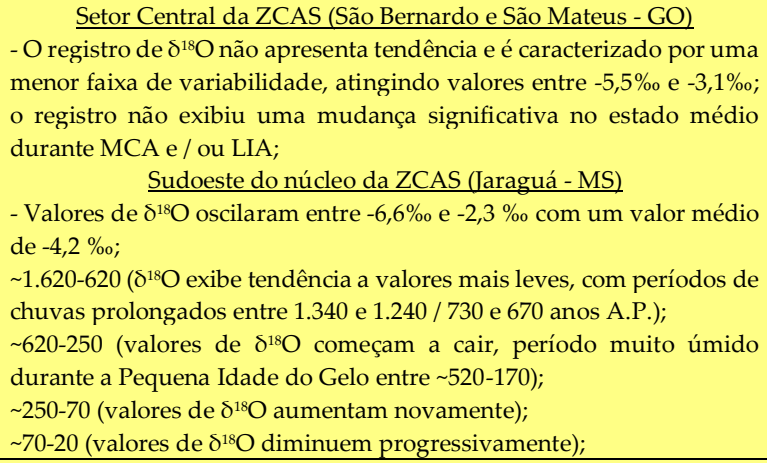 & $\begin{array}{l}\text { Novello et al. } \\
\text { (2018) }\end{array}$ \\
\hline & $\begin{array}{l}\text { Norte do Cerrado } \\
\text { Estado de Tocantins } \\
\text { Natividade (TO) }\end{array}$ & $\begin{array}{c}\text { Isotópico em } \\
\text { espeleotema da } \\
\text { Caverna Mata } \\
\text { Virgem (TO) } \\
\left(11^{\circ} 37^{\prime} 27.07^{\prime \prime S} \text {, }\right. \\
\left.47^{\circ} 29^{\prime} 19.04^{\prime \prime} \mathrm{W}\right)\end{array}$ & $\begin{array}{l}\text { U-Th } \\
\delta^{13} \mathrm{C} \\
\delta^{18} \mathrm{O}\end{array}$ & 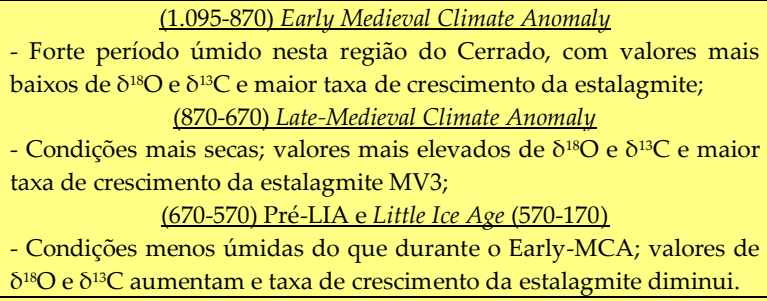 & $\begin{array}{c}\text { Azevedo et al. } \\
\text { (2019) }\end{array}$ \\
\hline & $\begin{array}{c}\text { Cerrado Central } \\
\text { Estado de Goiás } \\
\text { Formosa (GO) }\end{array}$ & $\begin{array}{l}\text { Palinológico em } \\
\text { sequência de } \\
\text { depósito lacustre } \\
\text { da Lagoa Feia } \\
(\mathrm{GO}) \\
\left(15^{\circ} 34^{\prime} \mathrm{S} / 47^{\circ} 18^{\prime} \mathrm{W}\right)\end{array}$ & $\begin{array}{c}\text { XRD } \\
{ }^{14} \mathrm{C} \text { (AMS) }\end{array}$ & 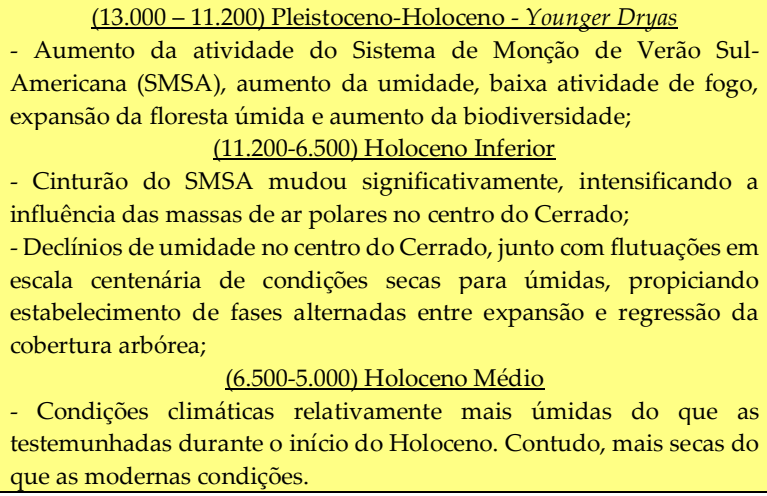 & $\begin{array}{l}\text { Cassino et al. } \\
\qquad(2020)\end{array}$ \\
\hline
\end{tabular}


No decorrer do Holoceno Médio e Superior, as condições de umidade diminuíram ainda mais, atingindo os valores de precipitações atuais, convergindo para um UMG mais úmido que os últimos 11.700 anos A.P. O recorte temporal associado ao Holoceno Superior, revelou mais detalhes das variabilidades hidroclimáticas em escalas centenárias, sinalizando para tendências importantes durante a Anomalia Climática Medieval e Pequena Idade do Gelo (NOVELLO et al., 2016, 2018; WORTHAM et al., 2017; AZEVEDO et al., 2019; CASSINO et al., 2020).

Deste modo, os resultados das pesquisas no Holoceno Superior, indicaram um enfraquecimento do SMSA e condições climáticas relativamente mais secas durante a MCA, quando comparado ao vigente na LIA, associado a um período mais úmido. Os resultados também apontaram para uma menor taxa de variabilidade do SMSA no corredor central da ZCAS (WORTHAM et al. 2017; AZEVEDO et al., 2019), divergindo dos setores a sudoeste do núcleo da ZCAS, que exibiram mudanças significativas no estado médio, associadas a maior variabilidade das atividades do SMSA (NOVELLO et al., 2016, 2018). Tais resultados, obtidos pelos autores citados, confirmam a existência de mudanças divergentes nos padrões climáticos influenciado pela posição da ZCAS, que durante a LIA, estacionava com maior frequência a sudoeste.

\subsubsection{Mata Atlântica}

Na região tropical e subtropical Atlântica, os mecanismos de controle climáticos atuais e pretéritos vinculamse aos mesmos observados na região do cerrado brasileiro. No entanto, em razão da sua posição, a região atlântica também experimenta a influência de outras atividades de circulação atmosférica, tais como as massas de ar secas e relativamente quentes provenientes da alta subtropical do Atlântico Sul (ASAS) e das massas de ar frias e secas, associadas às frentes frias polares, que afetam o clima atlântico tanto no inverno como no verão.

Durante o inverno e início da primavera, as incursões da frente fria polar em latitudes médias resultam em tempestades ciclônicas a partir do choque do ar frio do continente com o ar mais quente vindo do interior do oceano Atlântico (ASAS). Esta dinâmica propicia que os sistemas frontais sejam deslocados para o interior próximo do oceano Atlântico subtropical, afastando as instabilidades tropicais continentais por meio da redução da umidade atmosférica. Nestes períodos, o corredor enfraquecido da ZCIT localiza-se mais ao norte, inibindo a formação da ZCAS e propiciando o desenvolvimento de condições mais secas (CRUZ et al., 2005; TAYLOR, 2010; VUILLE et al. 2012; SMITH; MAYLE, 2018).

No verão e início de outono, as chuvas estão mais relacionadas à intensa convecção sobre o interior da bacia amazônica, trata-se da relação de dependência entre taxas de irradiação solar; aumento de temperatura da superfície da água do oceano Atlântico em zona equatorial; atuação dos alísios induzindo as atividades do SMSA por meio de profundas convecções promovidas pelo fortalecimento da ZCIT; impulsão da umidade e instabilidade conectiva promovida pelos Jet Streams andinos (JST), alta da Bolívia (AB) e desenvolvimento do cinturão da ZCAS. Esta última, apresenta-se responsável por irrigar o sudeste, sul e a faixa atlântica tropical/subtropical brasileira por meio das atividades do SMSA (CRUZ et al., 2005; TAYLOR, 2010; VUILLE et al. 2012; SMITH; MAYLE, 2018). Contudo, contrapondo-se a esta dinâmica, por vezes a ASAS pode avançar sobre o continente sul-americano durante o verão, induzindo situações de bloqueio atmosférico e acarretando períodos de chuvas irregulares (veranicos).

Diferentemente do cerrado, os registros isotópicos e palinológicos provenientes da mata atlântica, aparentemente, se correlacionam bem durante o Pleistoceno Superior e Holoceno. De modo geral, os registros palinológicos indicaram condições mais secas e frias durante o fim do último período glacial (48.000-18.000 anos A.P.). Fases correlacionadas à intensificação das frentes frias da Antártica (arrefecimento entre 5 e $7^{\circ} \mathrm{C}$ ), as quais ocasionaram significativa redução da floresta tropical semidecídua e floresta atlântica costeira. Tais formações 
vegetais foram substituídas por pastagens e florestas de galeria subtropical no decorrer de $750 \mathrm{~km}$, entre latitudes de cerca de $28^{\circ} \mathrm{S} / 27^{\circ} \mathrm{S}$ a pelo menos $20^{\circ} \mathrm{S}$ (sul e sudeste do Brasil) (BEHLING, 2002).

Quadro 3. Tendências paleoclimáticas na mata atlântica ao longo do Pleistoceno Superior e Holoceno.

\begin{tabular}{|c|c|c|c|c|c|}
\hline Bioma & $\begin{array}{c}\text { Localização da } \\
\text { Região }\end{array}$ & Tipo de Registro & Método & Tendências paleoclimáticas (anos A.P.) & Referências \\
\hline \multirow{5}{*}{ 岁 } & $\begin{array}{l}\text { Estados de Minas } \\
\text { Gerais, Rio de } \\
\text { Janeiro, Espírito } \\
\text { Santo, São Paulo, } \\
\text { Paraná, Santa } \\
\text { Catarina e Rio } \\
\text { Grande do Sul }\end{array}$ & $\begin{array}{c}\text { Síntese e análise } \\
\text { de } 14 \text { registros } \\
\text { palinológicos das } \\
\text { regióes sul e } \\
\text { sudeste do Brasil } \\
\text { (Behling, 2002) } \\
\\
\text { Síntese e análise } \\
\text { de } 19 \text { registros } \\
\text { palinológicos das } \\
\text { regióes sul e } \\
\text { sudeste do Brasil e } \\
\text { correlações com } \\
\text { dados isotópicos. } \\
\text { Rodrigues, Behling } \\
\text { e Giesecke (2016) }\end{array}$ & ${ }^{14} \mathrm{C}(\mathrm{AMS})$ & $\begin{array}{l}\text { Último período glacial no SE e S do Brasil } \\
\text { - Clima marcadamente mais seco e } 5-7^{\circ} \mathrm{C} \text { mais frio devido a maior } \\
\text { intensidade das frentes frias da Antártica; } \\
\text { - A floresta tropical semidecídua, o cerrado e a floresta atlântica da } \\
\text { planície costeira foram significativamente reduzidas e substituídas por } \\
\text { pastagens e florestas de galeria subtropical; } \\
\text { - As pastagens se estenderam por } 750 \mathrm{~km} \text { do S ao SE do Brasil. } \\
\quad(11.700-5.000) \text { Holoceno Inferior e Médio no S e SE do Brasil } \\
\text { - Condições climáticas secas, período seco anual de } 3 \text { meses; } \\
\text { - Enormes áreas de vegetação de campos do Pleistoceno Superior ainda } \\
\text { eram encontradas nas terras altas do sul. } \\
\quad \text { (5.000-atual) Holoceno Superior no S e SE do Brasil } \\
\text { - Condições úmidas com nenhum ou apenas curtos períodos secos; } \\
\text { - Expansão da Mata Atlântica nas regiões costeiras do sul e para o sul da } \\
\text { Amazônia ao longo de sua fronteira sudoeste; } \\
\text { - Florestas de Araucária substituíram grandes áreas de pastagem após } \\
\text { 3.000 anos A.P. e após } 1500 / 1000 \text { anos A.P. }\end{array}$ & $\begin{array}{l}\text { Rodrigues, } \\
\text { Behling e } \\
\text { Giesecke } \\
\text { (2016) }\end{array}$ \\
\hline & $\begin{array}{c}\text { Sul da Mata Atlântica } \\
\text { Estado de Santa } \\
\text { Catarina } \\
\text { Botuverá (SC) }\end{array}$ & $\begin{array}{c}\text { Isotópico em } \\
\text { espeleotema da } \\
\text { caverna Botuverá } \\
\left(27^{\circ} 13^{\prime} \mathrm{S} / 49^{\circ} 09^{\prime} \mathrm{W}\right)\end{array}$ & $\begin{array}{l}\delta^{18} \mathrm{O} \\
\mathrm{U} / \mathrm{Th}\end{array}$ & $\begin{array}{l}\quad \frac{(116.000 \text { - Atual) Mudanças na circulação atmosférica }}{\text { - }{ }^{18} \mathrm{O} \text { variaram de }-0.5 \% \text { a }-5.0 \% \text { com uma ciclicidade de } 20.000} \text { anos; } \\
\text { - Sobrepostas à ciclicidade de longo prazo estão variações mais abruptas } \\
\text { da escala milenar com amplitude de } ~ 1-1,5 \% \text { \% } \\
\text { - Valores mais baixos de } \delta^{18} \mathrm{O} \text { são observados por volta de } 14.000-20.000 \\
\text { e } 40.000-45.000 \text { anos A.P. (condições mais úmidas que as atuais); } \\
\text { - Valores } \delta^{18} \mathrm{O} \text { são progressivamente mais negativos no Holoceno; } \\
\text { - Tais variações na fonte e quantidade de chuva (SMSA / ZCAS) foram } \\
\text { impulsionadas pela radiação solar de verão; } \\
\text { - Os ciclos Dansgaard-Oeschger }(\mathrm{D} / \mathrm{O}) \text { afetaram o ciclo hidrológico tropical. }\end{array}$ & $\begin{array}{l}\text { Cruz et al. } \\
\text { (2005) }\end{array}$ \\
\hline & $\begin{array}{c}\text { Sul da Mata Atlântica } \\
\text { Estado de Santa } \\
\text { Catarina } \\
\text { Botuverá (SC) }\end{array}$ & $\begin{array}{c}\text { Isotópico em } \\
\text { espeleotema da } \\
\text { caverna Botuverá } \\
\left(27^{\circ} 13^{\prime} \mathrm{S} / 49^{\circ} 09^{\prime} \mathrm{W}\right)\end{array}$ & $\begin{array}{l}\delta^{18} \mathrm{O} \\
\mathrm{U} / \mathrm{Th}\end{array}$ & $\begin{array}{l}\text { Último período glacial } \\
\text { - } \delta^{18} \mathrm{O} \text { é relativamente baixo durante o último período glacial, com } \\
\text { valores mínimos }(\sim-5 \% \text { ) em } 36.000,29.900,25.800 \text { e } 18.400 \text { anos A.P, } \\
\text { correspondendo períodos de maior umidade durante o período glacial; } \\
\text { - Valores relativamente altos }(\sim-3 \% \text { a }-2 \% \text { o ocorreram em torno de } \\
22.700,27.900,29.200,32.600,33.500 \text { e } 34.600 \text { anos A.P., correspondendo } \\
\text { períodos de maior secura durante o período glacial (D/O } 2,3,4,5,6 \text { e } 7) \text {. }\end{array}$ & $\begin{array}{l}\text { Wang et al. } \\
\text { (2006) }\end{array}$ \\
\hline & $\begin{array}{c}\text { Sudeste da Mata } \\
\text { Atlântica } \\
\text { Estado de São Paulo } \\
\text { Iporanga (SP) }\end{array}$ & $\begin{array}{l}\text { Isotópico em } \\
\text { espeleotema da } \\
\text { caverna Cristal } \\
\left(24.58^{\circ} \mathrm{S} / 48^{\circ} 58^{\prime} \mathrm{W}\right)\end{array}$ & $\begin{array}{l}\mathrm{U} / \mathrm{Th} \\
\delta^{18} \mathrm{O} \\
\delta^{13} \mathrm{C}\end{array}$ & 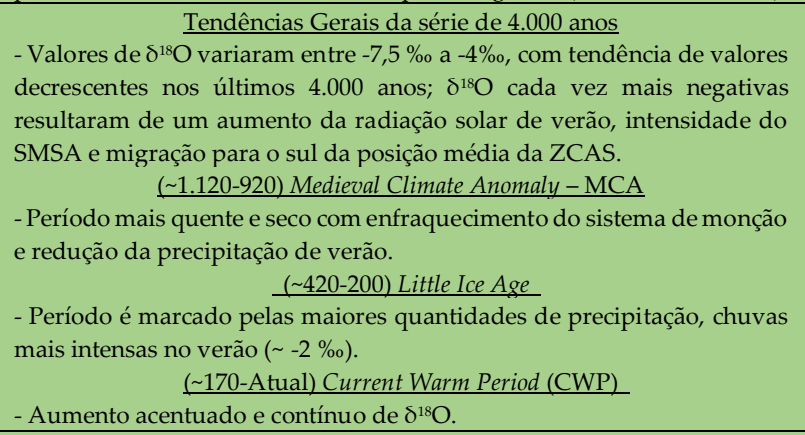 & $\begin{array}{l}\text { Vuille et al. } \\
\text { (2012) }\end{array}$ \\
\hline & $\begin{array}{l}\text { Estados de Minas } \\
\text { Gerais, Rio de } \\
\text { Janeiro, Espiríto } \\
\text { Santo, São Paulo, } \\
\text { Paraná, Santa } \\
\text { Catarina e Rio } \\
\text { Grande do Sul }\end{array}$ & $\begin{array}{l}\text { Síntese e análise de } \\
48 \text { registros } \\
\text { multiproxies } \\
\text { palinológicos, } \\
\text { isotópicos, } \\
\text { bioquímicos, } \\
\text { físicos e de carvão }\end{array}$ & $\begin{array}{c}\mathrm{U} / \mathrm{Th} \\
\delta^{18} \mathrm{O} \\
\delta^{13} \mathrm{C} \\
\mathrm{BiSi} \\
{ }^{14} \mathrm{C} \text { (AMS) }\end{array}$ & $\begin{array}{l}\text { (6.500-5.000) Holoceno Médio no S e SE do Brasil } \\
\text { - Condições climáticas mais secas vinculadas ao SMSA mais fraco, } \\
\text { favorecendo o aumento na duração da estação seca e a expansão de } \\
\text { vegetação mais aberta (cerrado / pastagem); } \\
\text { - Expansão de pastagens ao longo das terras altas do sul do Brasil. } \\
\quad \text { (5.000-atual) Holoceno Superior no S e SE do Brasil } \\
\text { - Aumento do transporte de umidade da bacia amazônica para o SE do } \\
\text { Brasil iniciou-se a partir de } \sim 4.000 \text { anos A.P., favorecendo o aumento da } \\
\text { precipitação e a expansão de florestas úmidas; } \\
\text { - A fase inicial de expansão da Araucária ocorreu por volta de } 4.000-3.500 \\
\text { anos A.P. na forma de florestas de galeria. A segunda fase de expansão } \\
\text { ocorreu a partir dos últimos } 1.500-1.000 \text { anos A.P. }\end{array}$ & $\begin{array}{c}\text { Smith e } \\
\text { Mayle (2018) }\end{array}$ \\
\hline
\end{tabular}

Os registros isotópicos de espeleotemas da caverna Botuverá (SC), também apresentaram variações que indicam o desenvolvimento de tendência climática a longo prazo mais seca entre 40.000-20.000 anos A.P. Contudo, interrompida por condições mais úmidas que as atuais entre 20.000-14.000 anos A.P. (UMG) e 40.000-45.000 anos 
A.P. (CRUZ et al., 2005) e, especialmente em 36.000, 29.900, 25.800 e 18.400 anos A.P. (WANG et al., 2006), não detectadas pelas análises palinológicas (BEHLING, 2002). As secas mais severas deste período apresentaram correlações com ciclos Dansgaard-Oeschger 2, 3, 4, 5, 6 e 7 (CRUZ et al., 2005; WANG et al., 2006).

Durante a transição do Pleistoceno/Holoceno (época de degelo glacial) e Holoceno Inferior, as condições de umidade inferidas para o UMG diminuíram drasticamente, acarretando período de severa secura até 8.700 anos A.P. Condições responsáveis por desenvolver enormes áreas de vegetação de campos, principalmente nas terras altas do sul do Brasil (BEHLING, 2002; RODRIGUES; BEHLING; GIESECKE, 2016).

No decorrer do Holoceno Inferior, Médio e Superior, após a fase seca que se prolongou até 8.700 anos A.P, os registros isotópicos das cavernas Botuverá (SC) e Cristal (SP) tornam-se progressivamente mais negativos ao longo do Holoceno $\left(\delta^{18} \mathrm{O}\right)$, indicando retomada e aumento da umidade da bacia amazônica para o sudeste do Brasil até atingir as condições modernas (CRUZ et al., 2005; WANG et al., 2006; TAYLOR, 2010; VUILLE et al., 2012). Período em que estudos palinológicos indicam expansão da mata atlântica nas regiões costeiras do sul do Brasil; expansão da mata atlântica para o sul da floresta Amazônica ao longo de sua fronteira sudoeste; e expansão de Araucárias substituindo grandes áreas de pastagem, principalmente após 3.000 e 1500/1000 anos A.P. (BEHLING, 2002; RODRIGUES; BEHLING; GIESECKE, 2016; SMITH; MAYLE, 2018).

A partir de recorte temporal vinculado ao Holoceno Superior (últimos 4.000 anos A.P.), os registros isotópicos em espeleotemas da caverna Cristal (SP), indicaram pulso climático mais quente e seco durante a Anomalia Climática Medieval ( 1.120-920 anos A.P.) e chuvas intensas durante a Pequena Idade do Gelo ( 420-200 anos A.P) (TAYLOR, 2010; VUILLE et al., 2012).

Por fim, ressalta-se que tais tendências climáticas a longo prazo na mata atlântica, descritas para o Pleistoceno Superior e Holoceno, apresentaram correlações com as mudanças na insolação solar atreladas ao ciclo de precessão da Terra. Nesse sentido, os autores apontaram que durante os mínimos na radiação solar ( 25.000 e 40.000 anos A.P e degelo pós-glacial), a localização média do SMSA e da ZCAS talvez tenha se deslocado para o norte, disponibilizando menos umidade da bacia amazônica para o sudeste. Em oposição, durante os máximos de insolação de verão, antecedentes ao degelo e optimum climático holocênico, possivelmente a localização média do SMSA e da ZCAS tenha se deslocado para o sul, intensificando a convergência da umidade para os setores atlânticos (CRUZ et al., 2005; WANG et al., 2006).

\subsubsection{Pantanal}

Em relação à extensão do bioma do pantanal (Quadro 4), foram abordados registros paleoclimáticos de setores centrais (MCGLUE et al., 2012) e meridionais (MCGLUE et al., 2017; BECKER et al., 2018; RASBOLD et al., 2019). Importante salientar, que enquanto coexistem diversas tentativas de reconstruções paleoclimáticas para outros biomas, no pantanal, as pesquisas ainda se apresentam incipientes, entretanto, vêm crescendo na última década.

Por meio dos resultados das pesquisas citadas no parágrafo anterior, nota-se que o pantanal experimentou condições paleoclimáticas semelhantes as descritas para o sudoeste do cerrado. Esta conexão ocorre em razão de serem locais modelados pelas mesmas forçantes climáticas e mecanismo de circulação atmosféricas, responsáveis por imporem padrões climáticos semelhantes. Contudo, obviamente coexistem ligeiras variações em relação aos ritmos e intensidades de atuação dos pulsos a partir das especificidades e singularidades entre os sistemas ambientais. 
Quadro 4. Tendências paleoclimáticas no pantanal ao longo do Pleistoceno Superior e Holoceno

\begin{tabular}{|c|c|c|c|c|c|}
\hline Bioma & Localização da Região & Tipo de Registro & Método & Tendências paleoclimáticas (anos A.P.) & Referências \\
\hline \multirow{3}{*}{ 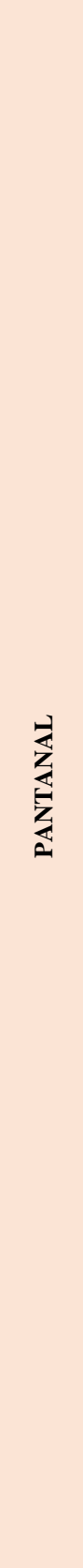 } & $\begin{array}{c}\text { Pantanal Central } \\
\text { Divisa do Brasil } \\
\text { (Corumbá-MS) com a } \\
\text { Bolívia (Pôrto Quijarro) }\end{array}$ & $\begin{array}{c}\text { Isotópico, químico e } \\
\text { fitólitos em } \\
\text { sedimentos das } \\
\text { Lagoas Gaíva e } \\
\text { Mandioré na Margem } \\
\text { oeste do Alto rio } \\
\text { Paraguai }\end{array}$ & $\begin{array}{c}\delta^{13} \mathrm{C} \\
{ }_{14} \mathrm{C}(\mathrm{AMS}) \\
\mathrm{TOC} \\
\mathrm{OM} \\
\mathrm{BiSi} \\
\mathrm{C}: \mathrm{N}\end{array}$ & $\begin{array}{l}\qquad(\sim 11.000 \text { a } 6.200) \text { Holoceno Inferior } \\
\text {-Fraca atividade do SMSA, baixos níveis de água nas lagoas; } \\
\text { - A inundação do rio Paraguai que ocorreu antes de } \sim 2.600 \text { foi } \\
\text { episódica e fraca em comparação com o pulso de inundação } \\
\text { moderno. } \\
\quad(\sim 6.200 \text { a } 440) \text { Holoceno Médio e Holoceno Superior } \\
\sim 6.200 \text { a } 5.300 \text { (pulsos de inundações mais frequentes); } \\
\sim 5.300 \text { a } 2.600 \text { (Episódio de seca com confinamento do rio } \\
\text { Paraguai em seu canal); } \\
\sim 2.600-400 \text { (fortes inundações do rio Paraguai em resposta ao } \\
\text { forte SMSA e valores acentuados da temperatura da superfície } \\
\text { do oceano Pacífico tropical); } \\
\sim \text { Grande pulso de inundação durante a Little Ice Age (LIA). }\end{array}$ & $\begin{array}{c}\text { McGlue et al. } \\
\text { (2012) }\end{array}$ \\
\hline & $\begin{array}{c}\text { Sul do Pantanal } \\
\text { Mato Grosso do Sul (MS) } \\
\text { Corumbá (MS) } \\
\text { Fazenda Nhumirim }\end{array}$ & $\begin{array}{l}\text { Isotópico, bioquímico, } \\
\text { físico e fácies } \\
\text { estratigráficas em } \\
\text { sedimentos de três } \\
\text { lagos salinos da } \\
\text { Nhecolândia, } \\
\text { localizada ao sul do } \\
\text { rio Taquari, em setor } \\
\text { abandonado do } \\
\text { megaleque fluvial } \\
\left(18^{\circ} 59^{\prime} \mathrm{S} / 56^{\circ} 39^{\prime} \mathrm{W}\right)\end{array}$ & $\begin{array}{c}\text { XRD } \\
{ }^{14} \mathrm{C}(\mathrm{AMS}) \\
\mathrm{\delta}^{13} \mathrm{C} \\
\text { OSL/SAR } \\
\text { TIC } \\
\text { TOC } \\
\text { TN } \\
\mathrm{C} / \mathrm{N} \\
\mathrm{BiSi}\end{array}$ & 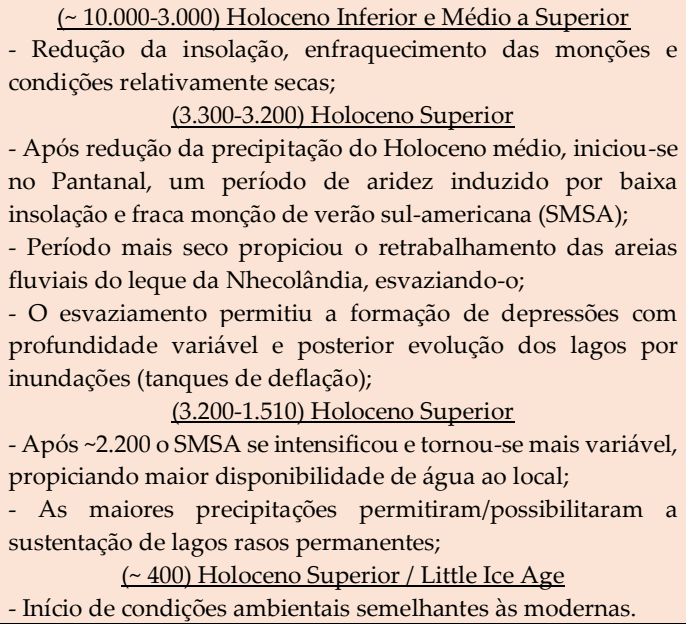 & $\begin{array}{l}\text { McGlue et al. } \\
\text { (2017) }\end{array}$ \\
\hline & $\begin{array}{l}\text { Sul do Pantanal } \\
\text { Mato Grosso do Sul (MS) } \\
\text { Corumbá (MS) }\end{array}$ & $\begin{array}{c}\text { Espículas de esponjas, } \\
\text { fitólitos e estratigrafia } \\
\text { de sedimentos da } \\
\text { Lagoa Negra, planície } \\
\text { de inundação do rio } \\
\text { Paraguai } \\
\left(19^{\circ} 04^{\prime} \mathrm{S} / 57^{\circ} 31^{\prime} \mathrm{W}\right)\end{array}$ & $\begin{array}{c}{ }^{14} \mathrm{C}(\mathrm{AMS}) \\
\delta^{13} \mathrm{C} \\
\text { OSL/SAR } \\
\text { TC } \\
\text { TIC } \\
\text { TOC }\end{array}$ & $\begin{array}{l}\text { ( } 19.000 \text { a } 11.700) \text { Pleistoceno Tardio Glacial e Deglacial } \\
\text { - A região do Pantanal foi submetida a uma forte monção; } \\
\text { - A LN, inexistente na época, foi submetida a fortes processos } \\
\text { deposicionais fluviais de canais secundários do rio Paraguai } \\
\text { durante } 2 \text { intervalos: } 19.000-18.360 \text { e } \sim 15.000-12.010 \text { anos A.P.. } \\
\quad(\sim 11.000 \text { a 5.660) Holoceno Inferior ao Holoceno Médio } \\
\text { - Declínio nas chuvas de monções no Pantanal; } \\
\text { - Ambiente lacustre começou a se expandir por volta de } \\
11.000 \text { anos A.P. devido ao isolamento da planície de } \\
\text { inundação do rio Paraguai; } \\
\text { - O isolamento ocorreu por confinamento do canal (baixo fluxo } \\
\text { de base) ou pelo desenvolvimento de diques marginais; } \\
\text { - O ambiente Lacustre da LN, embora raso, tornou-se mais } \\
\text { extenso e estável/perene entre } ~ 8.000 \text { e } 5.660 \text { anos A.P. } \\
\text { ( } 5.660 \text { a atual) Holoceno Médio ao Holoceno Superior } \\
\text { - A região foi submetida a uma fase seca por volta de } ~ 5.660 \text { a } \\
3.020 \text { anos A.P., ressecando a LN (evaporação da água); } \\
\text { - A LN estabeleceu características semelhantes a moderna em } \\
\text { torno } 1.000 \text { anos A.P. }\end{array}$ & $\begin{array}{l}\text { Rasbold et al. } \\
\text { (2019) }\end{array}$ \\
\hline
\end{tabular}

A gênese das zonas úmidas da região tropical do pantanal está vinculada com a tectônica andina (flexão crustal que originou áreas depressionárias) e ao ciclo anual de inundação do alto curso do rio Paraguai, responsável pelo alagamento generalizado que se observa ao longo da planície pantaneira durante a sazonalidade de verão austral. O interessante é que tais pulsos de inundação e, portanto, o desenvolvimento das planícies fluviolacustres, estão estreitamente conectados com a variabilidade das atividades do SMSA, influenciadas pelas profundas convecções promovidas pela ZCIT, impulsão promovida pelos JST e desenvolvimento de zonas de instabilidade conduzidas pela ZCAS (MCGLUE et al., 2012, 2017; BECKER et al., 2018; RASBOLD et al., 2019).

De modo geral, os resultados de pesquisas científicas apontaram que a região do pantanal, durante o Último Máximo Glacial ( 27.900-17.800 anos A.P.) e período deglacial ( 17.800 a 11.700 anos A.P.), foi submetida às fortes 
monções (SMSA), intensificando processos deposicionais fluviais de canais secundários do rio Paraguai durante dois intervalos de tempo (inundações), entre aproximadamente 19.000-18.360 e 15.000-12.010 anos A.P. (RASBOLD et al., 2019). Tais interpretações, vinculadas aos registros palinológicos e sedimentológicos da Lagoa Negra (MS), estão articuladas com os resultados publicados por Novello et al. (2017), obtidos a partir de registros isotópicos da Caverna Jaraguá (MS), onde também foi atribuída condições mais úmidas para o extremo sudoeste do cerrado ao longo do UMG.

Em relação ao Holoceno, por incrível que pareça para o Pantanal, nota-se o enfraquecimento das monções e condições cada vez mais secas em direção ao presente, induzida pela redução da insolação (MCGLUE et al., 2017; BECKER et al., 2018). No decorrer do Holoceno Inferior ao Holoceno Médio, o declínio das atividades do SMSA, provocou a expansão do ambiente lacustre devido ao isolamento da planície de inundação do alto rio Paraguai. Este isolamento ocorreu em razão do confinamento do canal (baixo fluxo de base) e/ou desenvolvimento de diques marginais (RASBOLD et al., 2019). Em um segundo momento, também devido ao enfraquecimento das atividades do SMSA, o pantanal foi submetido a um rebaixamento generalizado dos níveis de águas nas lagoas, possivelmente atrelados aos pulsos de inundação menos frequentes e mais fracos do alto rio Paraguai (MCGLUE et al., 2012; RASBOLD et al., 2019).

Ao longo do Holoceno Médio, evidências científicas sugeriram maior frequência dos pulsos de inundações ( 6.200 a 5.300 anos A.P.), seguido de episódio de seca que se prolongou no decorrer do Holoceno Superior, com novo confinamento do rio Paraguai em seu canal ( 5.300 a 2.600 anos A.P.). Iniciando-se na região depressionária, por volta de $3.300-3.200$ anos A.P., um período de aridez induzido por baixa insolação e fraca monção de verão sul-americana (MCGLUE et al., 2012, 2017; BECKER et al., 2018).

Após esta fase, os registros em questão, por volta de 2.600-400 anos A.P, apontaram para fortes inundações do alto rio Paraguai em resposta à intensificação das atividades do SMSA, induzidas pela elevação da temperatura da superfície do oceano Pacífico tropical. Dinâmica que permitiu a sustentação de lagos rasos permanentes nas planícies (MCGLUE et al., 2012; RASBOLD et al., 2019). Neste intervalo de tempo (Holoceno Superior), destaca-se o período da Pequena Idade do Gelo, que no pantanal também foi marcado por intenso pulso de inundação em razão do fortalecimento das chuvas de verão. Pulso climático mais úmido também identificado na amazônia, no cerrado e na mata atlântica (MCGLUE et al., 2017; BECKER et al, 2018; NOVELLO et al., 2018).

\subsubsection{Pampas}

Relativo à extensão do bioma pampeano (Quadro 5), houve à necessidade de abordar registros situados em países vizinhos em razão da pequena representatividade do bioma em solos brasileiros. Assim, foram selecionados registros ao norte do bioma, nas terras baixas do Estado do Rio Grande do Sul (BEHLING; PILLAR; BAUERMANN, 2005), a oeste das planícies pampeanas argentinas (IRIARTE, 2006) e a leste nas planícies costeiras do Uruguai (CUÑA-RODRÍGUEZ et al., 2020). Os registros e evidências paleoclimáticas da região pampeana situada ao sul da Argentina foram inseridos no tópico correspondente aos ambientes patagônicos, uma vez que este setor continental está diretamente associado ao domínio homônimo (MANCINI et al., 2005).

Os mecanismos de controles vinculados aos sistemas meteorológicos que causam precipitação na região pampeana da América do Sul, em parte, são distintos dos observados até o momento para os outros biomas. Por situar-se em faixas zonais subtropicais, a configuração de fases paleoclimáticas mais secas e/ou úmidas são controladas principalmente pela expansão de frentes frias, formação de sistemas frontais (SF) e complexos convectivos de mesoescala (CCM) que se movem na direção oeste-leste da sua região fonte. Vórtices ciclônicos de ar frio, que se formam na retaguarda de algumas frentes frias, também são responsáveis por causar fortes 
precipitações (RODRIGUES; FRANCO; SUGAHARA, 2004; BORSATO; MENDONÇA, 2015; CARDOSO NETA; SILVA, 2016; CARDOZO; REBOITA; GARCIA, 2015).

Atualmente, tais sistemas convectivos costumam se formar no Paraguai, norte da Argentina, Uruguai e sul do Brasil (locais dos registos abordados), principalmente no período de novembro a abril (CARDOSO NETA; SILVA, 2016). Geralmente, quando associados à atuação do fenômeno de El Niño, os volumes precipitados, frequentemente tendem a dobrar, em função da maior intensidade dos jatos de baixo nível sul-americano (JBNSA), responsáveis pelo transporte de umidade necessária para a formação das nuvens e precipitação na região (RODRIGUES; FRANCO; SUGAHARA, 2004; CARDOZO; REBOITA; GARCIA, 2015).

De modo geral, os resultados das pesquisas homônimas, apontaram para o predomínio de condições paleoclimáticas frias e relativamente secas durante todo o UMG e no decorrer da deglaciação no Pleistoceno Superior. Em relação ao Holoceno, as interpretações realizadas a partir das análises dos registros palinológicos, convergiram para uma retomada de umidade a níveis subtropicais atuais (BEHLING; PILLAR; BAUERMANN, 2005; IRIARTE, 2006; CUÑA-RODRIGUEZ et al., 2020).

Quadro 5. Tendências paleoclimáticas nos pampas ao longo do Pleistoceno Superior e Holoceno

\begin{tabular}{|c|c|c|c|c|c|}
\hline Bioma & Localização da Região & Tipo de Registro & Método & Tendências paleoclimáticas (anos A.P.) & Referências \\
\hline \multirow{3}{*}{$\sum_{\substack{\infty \\
\infty}}^{\infty}$} & $\begin{array}{c}\text { Norte do Pampa } \\
\text { Rio Grande do Sul (RS) } \\
\text { São Francisco de Assis }\end{array}$ & $\begin{array}{l}\text { Palinológicos em } \\
\text { sedimentos da turfeira } \\
\text { do pântano Itajuru } \\
\left(29^{\circ} 35^{\prime} \mathrm{S} / 55^{\circ} 13^{\prime} \mathrm{W}\right)\end{array}$ & ${ }^{14} \mathrm{C}$ (AMS) & $\begin{array}{l}\text { - A região foi coberta por campos durante todo o UMG } \\
\text { (condições frias e relativamente secas) e Holoceno Inferior } \\
\text { (condições quentes e secas); } \\
\sim 5.170-1550 \text { (Expansão inicial da floresta de galeria indica uma } \\
\text { mudança para condições climáticas mais úmidas); } \\
\sim 1.550-1.090 \text { (Máximo da expansão da floresta de galeria } \\
\text { refletindo o período mais úmido registrado). }\end{array}$ & $\begin{array}{l}\text { Behling, Pillar } \\
\text { e Bauermann, } \\
\text { (2005) }\end{array}$ \\
\hline & $\begin{array}{c}\text { Leste do Pampa } \\
\text { Sudeste do Uruguai }\end{array}$ & $\begin{array}{l}\text { Pólen e fitólito de } \\
\text { sedimentos das terras } \\
\text { úmidas da Índia } \\
\text { Muerta } \\
\left(33^{\circ} 42^{\prime} \mathrm{S} / 53^{\circ} 57^{\prime} \mathrm{W}\right)\end{array}$ & ${ }^{14} \mathrm{C}$ (AMS) & $\begin{array}{l}\text { 14.810-10.000 (condições mais secas e frias com pastagem); } \\
\text { 10.000-6.620 (clima mais quente e úmido do Holoceno, com } \\
\text { pico em } 9.450 \text { anos A.P., formação de turfa); } \\
\sim 6.620-4.000 \text { (período mais severo de seca); } \\
\sim 4.020 \text {-Atual (condições climáticas mais úmidas e estáveis). }\end{array}$ & Iriarte (2006) \\
\hline & $\begin{array}{c}\text { Oeste do Pampa } \\
\text { Planícies Pampeanas } \\
\text { da Argentina }\end{array}$ & $\begin{array}{l}\text { Palinológico em } \\
\text { sedimentos da Lagoa } \\
\text { Mar Chiquita, } \\
\left(30^{\circ} 54^{\prime} \mathrm{S} / 62^{\circ} 51^{\prime} \mathrm{W}\right)\end{array}$ & $\begin{array}{l}{ }^{14} \mathrm{C}(\mathrm{AMS}) \\
\delta^{13} \mathrm{C} \\
\text { TOC } \\
\text { TIC } \\
\mathrm{C} / \mathrm{N}\end{array}$ & $\begin{array}{l}\text { 12.800-11.600 (Fase úmida vinculada ao EPAC); } \\
\text { 11.500-10.500 (níveis de água altos, síncrono com o término do } \\
\text { Evento Pluvial Andino Central - EPAC); } \\
\text { 10.500-9.000 (condições alternadas de seca / chuva); } \\
\text { 8.200-4.200 (condições mais secas, menor precipitação } \\
\text { atribuído a uma intensidade de monção suprimida, com } \\
\text { pequenos pulsos de úmidos em } 6.400 \text { e } 5.200 \text { anos A.P.); } \\
\text { 1400-800 (período quente/úmido durante a Anomalia } \\
\text { Climática Medieval, interrompido por fases frias/secas); } \\
\text { 800-250 (transição para condições mais secas com nítida } \\
\text { queda dos níveis de água durante a Pequena idade do Gelo } \\
\text { entre 500-100 anos A.P.); }\end{array}$ & $\begin{array}{l}\text { Cuña- } \\
\text { Rodríguez et } \\
\text { al. }(2020)\end{array}$ \\
\hline
\end{tabular}

Neste sentido, o Holoceno Inferior, nos pampas do Brasil, foi marcado por condições quentes e secas, seguida por mudanças para condições climáticas mais úmidas ao longo do Holoceno Médio (início da expansão das florestas de galeria nas terras baixas) e intensificada no Holoceno Superior (máximo da expansão das florestas de galeria nas terras baixas) (BEHLING; PILLAR; BAUERMANN, 2005).

Em relação às planícies pampeanas a oeste da Argentina, durante a transição Pleistoceno/Holoceno, CuñaRodríguez et al. (2020) indicaram a ocorrência de fase mais úmida vinculada às influências impostas pelo evento pluvial andino central, seguida por condições alternadas de seca e chuva no Holoceno Inferior, após o término do evento supracitado. No decorrer do Holoceno Médio, os resultados indicaram condições mais secas, atribuídas a uma intensidade de monção suprimida, com curtos pulsos úmidos observados entre 6.400 e 5.200 anos A.P. 
Enquanto para o Holoceno Superior, foram inferidos períodos mais quente e úmido durante a Anomalia Climática Medieval, com transição para condições mais secas ao longo da Pequena Idade do Gelo (CUÑA-RODRÍGUEZ et al., 2020).

Quanto aos setores situados a leste, nas planícies costeiras do Uruguai, os resultados dispostos por Iriarte (2006), apontaram para tendências paleoclimáticas quentes e úmidas durante o Holoceno Inferior, interrompidas por severo período de seca no Holoceno Médio, com retomada de umidade semelhantes às condições modernas ao longo do Holoceno Superior (IRIARTE, 2006).

Por meio destas pesquisas, verifica-se que a retomada de umidade ao longo do Holoceno ocorreu de maneira mais eficaz no Brasil, pois enquanto observou-se, em determinados momentos, condições mais secas na Argentina e Uruguai, a região pampeana do sul do Brasil apresentou tendências mais úmidas. Talvez, por posicionar-se mais próximo da ZCAS e do núcleo de precipitações mais intensas e frequentes associados aos CCM (oeste-leste). Em ambos os locais abordados houve predomínio de pastagens durante o Pleistoceno Superior e Holoceno (BEHLING; PILLAR; BAUERMANN, 2005; IRIARTE, 2006; CUÑA-RODRIGUEZ et al., 2020).

\subsubsection{Caatinga}

Com relação à extensão do bioma da caatinga (Quadro 6), foram abordados registros isotópicos em setores centrais do bioma (WANG et al., 2004); a oeste da caatinga (OLIVEIRA; BARRETO; SUGUIO, 1999), norte da caatinga (CRUZ et al., 2009); centro-sul da caatinga (NOVELLO et al., 2012) e transição do cerrado com o extremo sul da Caatinga (STRÍKIS et al., 2011, 2015, 2018).

O nordeste brasileiro apresenta regimes de precipitação variados e complexos, com baixos índices pluviométricos e alta evaporação em razão da elevada radiação solar incidente em baixas latitudes do hemisfério sul. Em relação aos sistemas meteorológicos que causam precipitações na região, o conhecimento é muito claro e envolvem três principais mecanismos. O primeiro, vincula-se à influência imposta pela circulação atmosférica promovida pela faixa de baixa pressão e convergência dos ventos alísios úmidos ascendentes (ZCIT). O segundo, relaciona-se com o transporte da umidade pela ZCAS até os domínios subtropicais, onde o ar descendente desenvolve o terceiro mecanismo, associado à formação de células de alta pressão semipermanentes sobre o oceano atlântico (ASAS).

Tais células de alta pressão, por sua vez, ao longo do verão austral, alimentam a circulação atmosférica ascendente na ZCIT, convergindo umidade para o nordeste e promovendo chuvas a partir do encontro das massas úmidas com as massas de ar secas do continente. Nesta dinâmica, as chuvas costumam ocorrer entre os meses de fevereiro a maio, quando os centros conectivos da ZCIT se posicionam em latitudes aproximadas de até $4^{\circ} \mathrm{S}$, desenvolvendo, por vezes, complexos convectivos de mesoescala (CCM) (LYRA, et al., 2020). Enquanto os períodos de severas estiagens, costumam ocorrer principalmente durante os meses de agosto e setembro, quando os centros conectivos da ZCIT se deslocam para norte e posicionam-se em latitudes aproximadas de $8^{\circ} \mathrm{N}$ (Figura 3). 


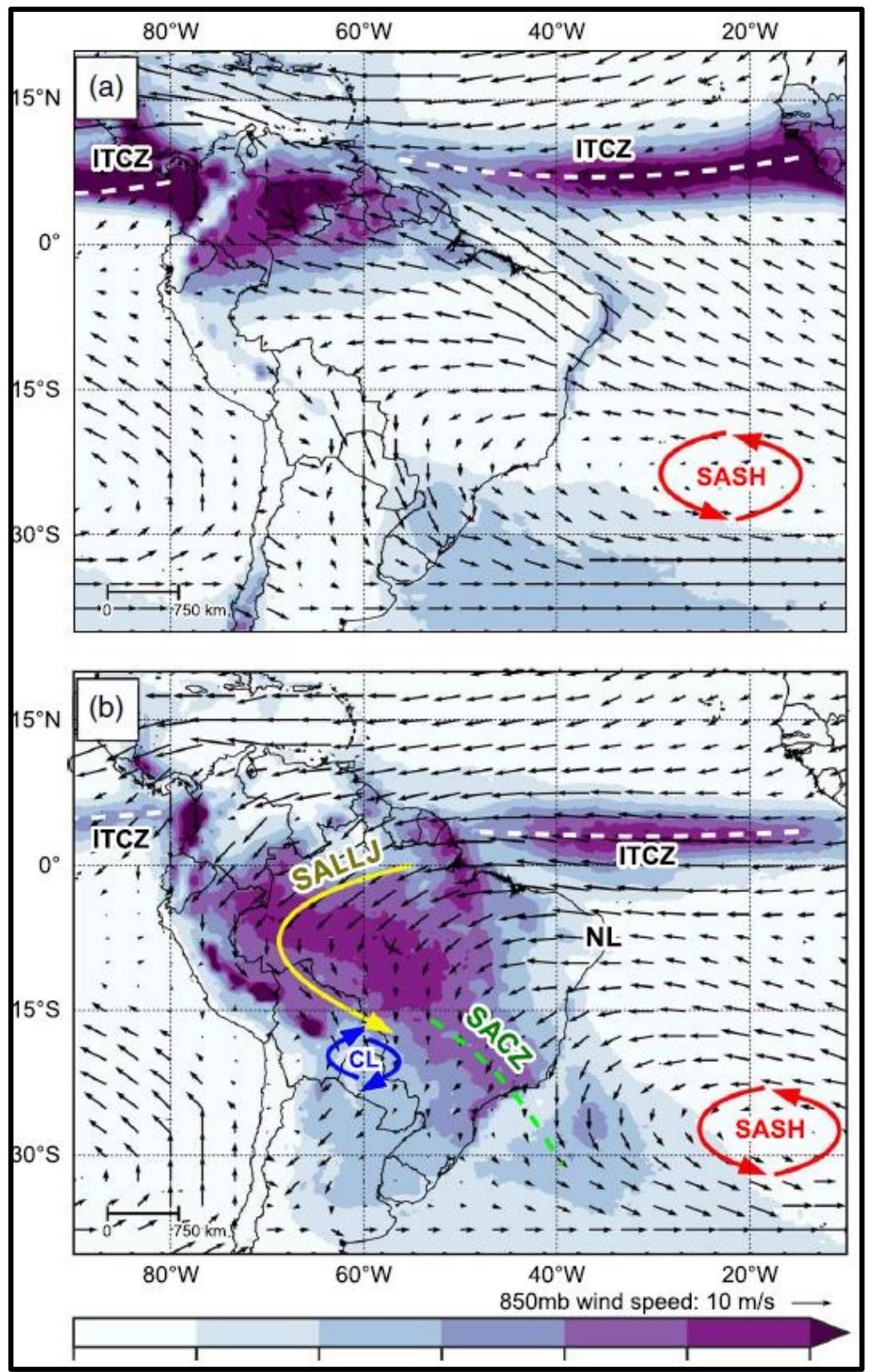

Figura 3. Precipitação média de longo prazo observada ( $\mathrm{mm} /$ dia), velocidade do vento de $850 \mathrm{mb}$ e direção do vento para (a) junho, julho e agosto (JJA) e (b) dezembro, janeiro e fevereiro (DJF). Siglas: ITCZ - Intertropical Convergence Zone (Zona de Convergência Intertropical - ZCIT); SALLJ - South American Low Level Jet (Jato de Baixo Nível sulamericano - JBNSA); CL - Chaco Low (Baixa do Chaco - BC); SACZ - South Atlantic Convergence Zone (Zona de Convergência do Atlântico Sul - ZCAS); SASH - South Atlantic Subtropical High (Alta Subtropical do Atlântico Sul ASAS); NL - Nordeste Low (Baixa do Nordeste - BN).

Fonte: Smith e Mayle (2018, p.135)

Verifica-se que as variações de posição e intensidade da ZCIT estão diretamente relacionadas às alterações nas posições e intensidades dos anticiclones subtropicais do atlântico sul (ASAS). Contudo, se por um lado é relativamente fácil apontar os principais mecanismos que originam as baixas precipitações do semiárido nordestino, não se pode afirmar o mesmo para os mecanismos que provocam um efeito inverso, relacionado às severas condições secas que induziram a expansão da caatinga.

Para tentar sanar este constante questionamento, foram formuladas diferentes hipóteses nas últimas décadas, as quais tentaram desvendar as principais causas responsáveis pelo desenvolvimento do regime climático 
semiárido no nordeste brasileiro. Entre as principais hipóteses, destacam-se as premissas vinculadas às barreiras orográficas que impedem a chegada de umidade (NIMER, 1989); confinamento do ar seco nas depressões interplanálticas (AB'SABER, 1999); posição geográfica com relação às massas de ar atuantes (NIMER, 1989); relações entre albedo (MOLION; BERNARDO, 2002); anomalias na temperatura na superfície do mar (KAYANO; ANDREOLI, 2009) e dinâmica das células de circulação geral da atmosfera (WALKER, 1928).

No momento, a hipótese mais coerente e aceita vincula-se à dinâmica das células de circulação geral da atmosfera, onde a semiaridez apresenta-se como decorrência da dinâmica imposta pela circulação meridional de Hadley e da subsidência associada ao ramo descendente da circulação de Walker. A partir desta teoria, o clima semiárido brasileiro seria definido pelo desenvolvimento de zonas de pressões atmosféricas dispersoras de vento e umidade, induzidas pela formação do anticiclone da Alta da Bolívia (AB) na alta troposfera, pela subsidência persistente relacionada ao cavado proeminente da Baixa do Nordeste $(\mathrm{BN})$ e pelo desenvolvimento de vórtices ciclônicos em altos níveis (VCAN) na alta troposfera (dipolo de precipitação leste-oeste da circulação de Walker) (Figura 3).

Em relação à circulação de Hadley, a posição da ZCIT se apresenta determinante para formação, localização e intensidade dos anticiclones que exercem influência para o estabelecimento de condições mais secas no nordeste, os quais estão associados tanto à $\mathrm{AB}$ quanto à ZCAS. Em relação à circulação de Walker, as intensas correntes de ar quente ascendentes no centro do continente (Alta da Bolívia e Baixa do Chaco), durante as monções tropicais da América do sul (bacia amazônica), suscitam movimentos de subsidência compensadora nas regiões circundantes (Atlântico tropical e nordeste), manifestando-se como uma característica de baixa pressão troposférica (Cavado da Baixa do Nordeste e VCAN) (Figura 3). Portanto, a atuação conjunta entre as células de Walker e Hadley, inibe movimentos ascendentes no nordeste (centro do VCAN), contribuindo para manutenção do clima semiárido na região da caatinga.

De forma secundária, os fatores geográficos e geomorfológicos também contribuem para a secura do clima nordestino, uma vez que os relevos planálticos circundantes exercem influência perante o barramento de umidade para o interior do semiárido nordestino. Trata-se do planalto da Borborema, do planalto do Urucuia (chapadas do São Francisco) e chapada Diamantina. Destes, o primeiro se apresenta determinante pela obliteração de parte das massas de ar úmidas advindas do oceano atlântico a leste (ventos alísios) e o segundo pelo barramento da umidade proveniente do transporte promovido pela ZCAS a oeste. Enquanto a chapada Diamantina e as depressões interplanálticas contribuem para confinamento do ar seco nos corredores centrais. Estas configurações geomorfológicas, também colaboraram para o desenvolvimento de áreas úmidas (barlavento) que margeiam setores mais áridos. Pode-se citar como exemplo as regiões litorâneas (zona da mata e agreste) e o cerrado subúmido situado na divisa entre os estados da Bahia, Tocantins e Goiás.

Com relação ao paleoclima do Pleistoceno Superior (Quadro 6), os resultados das pesquisas científicas apontaram que as condições úmidas no nordeste brasileiro foram incomuns ao longo dos últimos 210.000 anos A.P. (WANG et al., 2004). Todavia, para este mesmo período (últimos 210.000 anos A.P.), também foram observadas taxas de crescimento dos espeleotemas, sendo associados pelos pesquisadores a intervalos de eventos pluviais que duraram de centenas a poucos milhares de anos. 
Quadro 6. Tendências paleoclimáticas na caatinga ao longo do Pleistoceno Superior e Holoceno

\begin{tabular}{|c|c|c|c|c|c|}
\hline Bioma & Localização da Região & Tipo de Registro & Método & Identificação dos Pulsos Climáticos (anos A.P.) & Referências \\
\hline & $\begin{array}{c}\text { Caatinga Central } \\
\text { Estado da Bahia (BA) } \\
\text { Campo Formoso (BA) } \\
\text { Complexo Cárstico da Toca } \\
\text { da Boa Vista }\end{array}$ & $\begin{array}{l}\text { Isotópico em } \\
\text { espeleotemas das } \\
\text { Cavernas Lapa dos } \\
\text { Brejões e Toca da } \\
\text { Barriguda e em } \\
\text { depósitos de } \\
\text { travertino em vales } \\
\text { circundantes dos rios } \\
\text { Salitre e Jacaré } \\
\text { Análise de restos } \\
\text { vegetais } \\
\left(10^{\circ} 10^{\prime} \mathrm{S} / 40^{\circ} 50^{\prime} \mathrm{W}\right)\end{array}$ & $\begin{array}{l}\mathrm{U} / \mathrm{Th} \\
\delta^{18} \mathrm{O} \\
\delta^{13} \mathrm{C}\end{array}$ & $\begin{array}{l}\text { (210.000 a atual) Fases de crescimento dos espeleotemas } \\
\text { correlacionadas a períodos úmidos no nordeste brasileiro: } \\
\sim 11.700-12.100 \text { (Younger Dryas) / 16.700-21.700 (H1 e UMG) / } \\
\sim 39.600-38.900 \text { (H4) / 48.000 (H5) / 60.000-74.000 (H6) / } \\
86.500-87.200 / \sim 130.000-134.000 / \sim 178.000-182.000 / \sim 205.000- \\
206.000 / \sim 207.000-209.000 ; \\
\text { - Os períodos de crescimento do espeleotema ocuparam apenas } \\
\text { uma pequena fração }(\sim 8 \%) \text { dos últimos } 210.000 \text { anos A.P., } \\
\text { indicando que as condições pluviais eram incomuns no } \\
\text { nordeste brasileiro; } \\
\text { - As anomalias secas se correlacionam com anomalias de } \\
\text { temperaturas negativas da superfície do mar no Atlântico } \\
\text { tropical sul e positivas no Atlântico tropical norte; } \\
\text { - A expansão da floresta tropical ocorreu durante os intervalos } \\
\text { chuvosos, desenvolvendo corredor florestal entre as florestas } \\
\text { amazônica e atlântica por meio de matas galerias. }\end{array}$ & $\begin{array}{l}\text { Wang et al. } \\
\text { (2004) }\end{array}$ \\
\hline \multirow{3}{*}{ 岂 } & $\begin{array}{c}\text { Norte da Caatinga } \\
\text { Rio Grande do Norte (RN) } \\
\text { Felipe Guerra (RN) }\end{array}$ & $\begin{array}{c}\text { Isotópico em } \\
\text { espeleotemas das } \\
\text { Cavernas Rainha, } \\
\text { Furna Nova e Abissal } \\
\left(05^{\circ} 36^{\prime} \mathrm{S} / 37^{\circ} 44^{\prime} \mathrm{W}\right)\end{array}$ & $\begin{array}{l}\mathrm{U} / \mathrm{Th} \\
\delta^{18} \mathrm{O} \\
\delta^{13} \mathrm{C}\end{array}$ & $\begin{array}{l}\qquad(26.000-15.100) \text { Último período glacial } \\
\text { - Período com altos valores de } \delta^{18} \mathrm{O} \text { (média de }-2.91 \pm 0.57 \% \text { ), } \\
\text { indicando condições predominantemente secas, interrompidas } \\
\left.\text { por condições mais úmidas (baixos valores de } \delta^{18} \mathrm{O}\right) \text { durante os } \\
\text { eventos Heinrich } 2(-5.5 \% \text { ontre } 25.900 \text { e } 25.000) \text { e Heinrich } 1 \text { (- } \\
6.5 \% \text { o entre } 17.300 \text { e } 15.100 \text { anos A.P.); } \\
\quad(15.100-13.200) \text { Bølling-Allerød } \\
\text { - Nenhum depósito de espeleotema foi encontrado, } \\
\text { correspondendo a um período associado a severa seca; } \\
\text { - } 13.200-5.000) \text { Transição Pleistoceno/Holoceno/ Holoceno Inf. } \\
\text { - Período com grande variabilidade de valores de } \delta 18 O \text { em } \\
\text { modo geral, condições predominantemente úmidas; } \\
\quad \text { (5.000-atual) Holoceno médio ao Superior } \\
\text { - Aumento abrupto nos valores de valores de } \delta^{18} \mathrm{O}(1.5 \%) \text { entre } \\
5.000-4.200 \text { anos A.P. e aumento gradual nos valores de } \delta^{18} \mathrm{O} \\
\text { nos últimos } 3.700 \text { anos A.P, indicando condições secas no } \\
\text { Nordeste durante o Holoceno Superior. }\end{array}$ & $\begin{array}{l}\text { Cruz et al. } \\
\text { (2009) }\end{array}$ \\
\hline & $\begin{array}{l}\text { Centro-Sul da Caatinga } \\
\text { Estado da Bahia (BA) } \\
\text { Iraquara (BA) }\end{array}$ & $\begin{array}{l}\text { Isotópico em } \\
\text { espeleotemas das } \\
\text { Cavernas Diva de } \\
\text { Maura, Torrinha e } \\
\text { Lapa Doce (BA) } \\
\left(12^{\circ} 22^{\prime} \mathrm{S} / 41^{\circ} 34^{\prime} \mathrm{W}\right)\end{array}$ & $\begin{array}{l}\mathrm{U} / \mathrm{Th} \\
\delta^{18} \mathrm{O} \\
\delta^{13} \mathrm{C}\end{array}$ & $\begin{array}{l}\qquad \frac{(3.000-\text { Atual) Holoceno Superior }}{\text { - Os valores de } \delta^{18} \mathrm{O} \text { variam entre }-7,8 \text { e }-1,8 \% \text { oo longo dos }} \\
\text { últimos } 3.000 \text { anos A.P., com tendência decrescente nos níveis } \\
\text { de } \delta^{18} \mathrm{O} \text { em direção ao presente (mais seco); } \\
\text { - Períodos vinculados a LIA, MCA e CWP representam os mais } \\
\text { secos registrados nos últimos } 3.000 \text { anos A.P. (níveis de } \delta^{18} \mathrm{O} \\
\text { acima de }-2,5 \% \text { o), sugerindo que atualmente a região está } \\
\text { passando por condições de seca sem precedentes; } \\
\text { - Essa tendência de aridez foi interrompida por eventos } \\
\text { abruptos de chuva com periodicidade aproximada de } 210 \text { anos, } \\
\text { vinculadas as variações na intensidade do SMSA; } \\
\text { - Condições de maior umidade foram observadas durante o } \\
\text { evento Bond } 2 \text { entre } ~ 2.800-2.650 ;\end{array}$ & $\begin{array}{c}\text { Novello et al. } \\
\text { (2012) }\end{array}$ \\
\hline & $\begin{array}{l}\text { Cerrado com transição para } \\
\text { o extremo Sul da Caatinga, } \\
\text { Estado de Minas Gerais } \\
\text { Luislândia (MG) e } \\
\text { Montalvânia (MG) }\end{array}$ & $\begin{array}{c}\text { Isotópico em } \\
\text { espeleotemas das } \\
\text { Cavernas Paixão e } \\
\text { Marota (BA) } \\
\left(12^{\circ} 35^{\prime} \mathrm{S}, 41^{\circ} 02^{\prime} \mathrm{W}\right) \\
\left(12^{\circ} 37^{\prime} \mathrm{S} / 41^{\circ} 01^{\prime} \mathrm{W}\right)\end{array}$ & $\begin{array}{l}\mathrm{U} / \mathrm{Th} \\
\delta^{18} \mathrm{O} \\
\delta^{13} \mathrm{C}\end{array}$ & 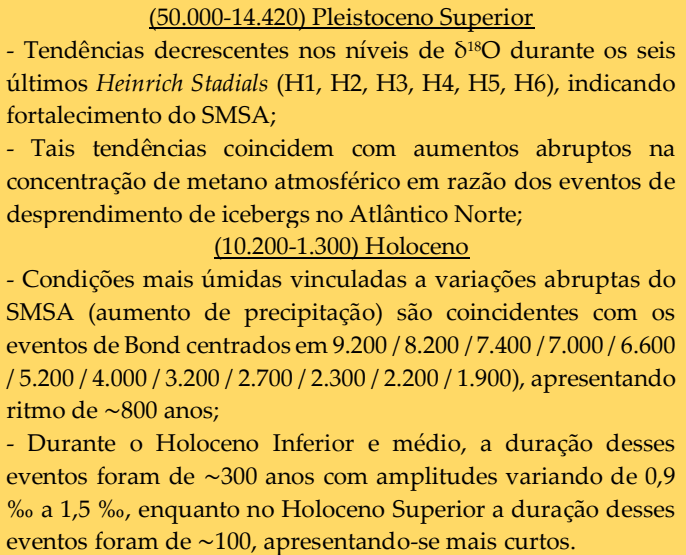 & $\begin{array}{l}\text { Stríkis et al. } \\
\qquad(2015)\end{array}$ \\
\hline
\end{tabular}


Para os autores, estas fases úmidas no Pleistoceno Superior, ocorreram de modo sincronizado com temperatura baixas do ar na Groenlândia, monções fracas do leste asiático, eventos Heinrich no Atlântico Norte (H6, H5, H4, H3, H2 e H1) e com a fase Younger Dryas que sucedeu o interestadial Bölling/Allerød (WANG et al., 2004; CRUZ et al., 2009; STRÍKIS et al., 2015, 2018).

Neste sentido, os pesquisadores explicaram que durante os eventos Heinrich, a intensificação das precipitações de neve no hemisfério norte, teria ocasionado a expansão dos glaciares continentais (América do Norte e Europa) e das plataformas de gelo sobre o mar nas regiões subtropicais do Atlântico Norte. Com isso, o frio teria modificado o transporte de calor ao norte do equador e alterado a circulação de ventos que carregam umidade, afetando o clima na América do Sul mediante deslocamento da ZCIT para várias centenas de quilômetros ao sul de seu limite meridional atual (fortalecimento dos ventos alísios no nordeste) (WANG et al., 2004; CRUZ et al., 2009; STRÍKIS et al. 2015, 2018).

Nesta dinâmica, eventos pluviais foram recorrentes na caatinga durante os eventos Heinrich, possibilitando o desenvolvimento de condições mais úmidas (WANG et al., 2004; CRUZ et al., 2009; STRÍKIS et al. 2015, 2018), enquanto os principais períodos secos estariam vinculados às anomalias de temperaturas negativas da superfície do mar no Atlântico tropical sul e positivas no Atlântico tropical norte (WANG et al., 2004).

Entre estes períodos mais úmidos, destacam-se o H4 ( 39.600 anos A.P.) e o H5 ( 48.000 anos A.P.), caracterizados por serem os mais longevos, impondo condições úmidas prolongadas, capazes de terem desenvolvido corredores de vegetação que ligaram setores da mata atlântica do nordeste com a floresta amazônica (WANG et al., 2004; CRUZ et al., 2009; STRÍKIS et al., 2015, 2018). Interpretações condizentes com estudos palinológicos que já haviam indicado a ocorrência desta dinâmica paleoecológica (OLIVEIRA, BARRETO e SUGUIO, 1999).

Em relação ao Holoceno, os registros isotópicos de espeleotemas do nordeste da ZCAS, registraram variações de precipitação na caatinga que são antifásicas com registros documentados na amazônia, Brasil central (cerrado) e sudeste do Brasil (mata atlântica), principalmente durante o período da Pequena Idade do Gelo. Estas constatações reforçam a dinâmica climática atual do nordeste descrita anteriormente, relativa ao dipolo de precipitação leste-oeste induzidos pela circulação de Walker (CRUZ et al., 2009).

Com relação aos registros isotópicos associados à transição entre cerrado e caatinga, talvez pela maior proximidade do corredor da ZCAS, apesentaram resultados um pouco distintos, pois foi observado maior frequência de pulsos climáticos úmidos frente às condições secas. Segundo os autores, tais eventos apresentaram correspondência impressionante com alguns eventos Bond durante o Holoceno Médio e Superior, elucidando ritmo de aproximadamente 800 anos, com duração aproximada de 300 anos no Holoceno Inferior/Holoceno Médio e de 100 anos durante o Holoceno Superior (STRÍKIS et al., 2011).

Nesta perspectiva, as 12 fases climáticas mais úmidas no Holoceno foram identificadas e centradas pelos autores em: 9.200 (Bond event 6); 8.200 (8.2 ka event); 7.400 (Bond event 5); 7.000 e 6.600 (não relacionados a eventos Bond), 5.200 (Bond event 4); 4.000 (não relacionados a eventos Bond), 3.200 (Bond event 2); 2.700, 2.300, 2.200 e 1.900 anos A.P. (não relacionados a eventos Bond) (STRÍKIS et al., 2011). A explicação apresentada para ocorrência destas fases úmidas, vinculam-se as mesmas descritas para o Pleistoceno Superior, uma vez que também foram correlacionadas com o deslocamento da posição latitudinal média da ZCIT em direção ao sul durante eventos de resfriamento no atlântico norte. Contudo, estes eventos no Holoceno, tiveram magnitudes menos pronunciadas que os eventos Heirench, ocorridos durante o último período glacial (STRÍKIS et al., 2011). 
Por fim, destaca-se Novello et al. (2012), que a partir de análise atrelada ao recorte temporal no Holoceno Superior (centro sul da caatinga), também trouxeram contribuições para o entendimento paleoclimático no nordeste brasileiro. Os autores indicaram que a região está atualmente passando por condições de seca sem precedentes nos últimos 3.000 anos A.P., principalmente durante a Anomalia Climática Medieval, Pequena Idade do Gelo e o atual período de aquecimento moderno. Todavia, a tendência seca de longo prazo foi interrompida por eventos abruptos de chuva com periodicidade aproximada de 210 anos, sendo o evento Bond 2, com ocorrência entre aproximadamente 2.800-2.650 anos A.P., o período de umidade mais intenso da série histórica observada (NOVELLO et al., 2012).

\subsubsection{Ambientes orogênicos e patagônicos}

Em relação às demais extensões da América do Sul (Quadro 7), foram abordados registros de ambientes orogênicos e patagônicos. A revisão buscou envolver testemunhos variados, bem distribuídos espacialmente, de modo que se tornassem representativos frente às variações latitudinais, longitudinais e altitudinais do restante do continente. Para tanto, foram envolvidos registros paleoclimáticas no setor norte da cordilheira dos Andes, situados próximos às regiões tropicais (KANNER et al., 2013; MUÑOZ et al., 2017) e setores adjacentes aos Andes centrais (JARA; MALDONADO; PORRAS, 2020), esculpidos no contexto das condições climáticas desérticas do Atacama (OLSON; DODDA; RIVERA, 2020).

Também foram envolvidos na análise, setores situados ao sul da Cordilheira dos Andes, contextualizados nos domínios patagônicos da América do Sul. Deste modo, foram destacadas tendências paleoclimáticas para o setor norte da patagônia andina, influenciados por condições climáticas temperadas (JARA et al., 2019); setores centrais da patagônia andina, em montanhas próximas a glaciares (REYNHOUT et al., 2019); setores da Terra do Fogo, ao sul da patagônia andina (GARCÍA et al., 2020); e setores localizados no extremo sul do continente sul-americano, próximo das influências climáticas polares (MCCULLOCH et al., 2020).

Por fim, também foi colocado em evidência um estudo de revisão bibliográfica que abordou múltiplos registros, bem distribuídos ao longo dos setores pampeanos e estépicos da patagônia oriental, a leste da Cordilheira dos Andes (MANCINI et al., 2005).

Em relação aos ambientes orogênicos da América do Sul, naturalmente notou-se variações nos ritmos, frequência e intensidades dos pulsos climáticos, impostos pelas especificidades dos sistemas ambientais atreladas às variações altitudinais e latitudinais inerentes ao continente (determinantes perante o condicionamento dos sistemas atmosféricos atuantes). Nota-se que apesar da estabilidade climática geral do Holoceno, pulsos ocorreram com frequência, acarretando curtos eventos que ocasionaram a modificação dos padrões atmosféricos e processuais, expressos por fenômenos vinculados à gênese Quaternária dos sistemas patagônicos e andinos.

Pode-se citar como exemplo, a ocorrência de pulsos climáticos quentes e secos no extremo norte dos Andes (11.410-10.700 / 9.700-6900 / 4.000-2400 anos A.P.), alternados por pulsos climáticos frios e úmidos ocorridos por volta de 10.700-9.700 / 6900 / 4.000 anos A.P. (MUÑOZ et al., 2017); pulsos climáticos úmidos generalizados nos andes centrais em aproximadamente 4.000-3.400 e 2.300-1.900 anos A.P. (JARA; MALDONADO; PORRAS, 2020); e prevalecimento de condições mais úmidas do que as condições modernas ao longo do Holoceno Inferior no deserto do Atacama, entre 11.700 e 8.600 anos A.P. (OLSON; DODDA; RIVERA, 2020). 
Quadro 7. Tendências paleoclimáticas em ambientes orogênicos e patagônicos durante o Pleistoceno Superior e Holoceno

\begin{tabular}{|c|c|c|c|c|c|c|}
\hline Ambi & ientes & Localização da Região & Tipo de Registro & Método & Identificação dos Pulsos Climáticos (anos A.P.) & Referências \\
\hline \multirow{4}{*}{\multicolumn{2}{|c|}{ 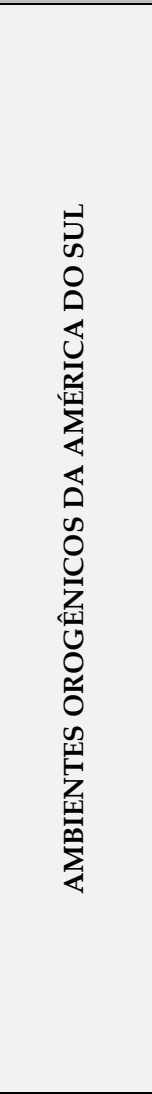 }} & $\begin{array}{l}\text { Norte dos Andes } \\
\text { (Sudeste do Peru) }\end{array}$ & $\begin{array}{l}\text { Isotópico em } \\
\text { espeleotemas da } \\
\text { Caverna Huagapo } \\
\left(11,27^{\circ} \mathrm{S} / 75,79^{\circ} \mathrm{W}\right)\end{array}$ & $\begin{array}{l}\mathrm{U} / \mathrm{Th} \\
\delta^{18} \mathrm{O} \\
\delta^{13} \mathrm{C}\end{array}$ & $\begin{array}{l}\text { Condições climáticas nos últimos } 7.150 \text { anos A.P } \\
\text { - Os valores de } \delta^{18} \mathrm{O} \text { variam entre }-14 \% \text { a }-12 \% \text { nos últimos } \\
7.150 \text { anos A.P., com tendência de diminuição gradual nos } \\
\text { níveis de } \delta^{18} \mathrm{O} \text { em direção a era moderna, elucidando } \\
\text { condições progressivamente mais úmidas ao longo do } \\
\text { Holoceno em razão do fortalecimento do SMSA; } \\
\text { - A diminuição gradual nos valores de } \delta^{18} \mathrm{O} \text { foi interrompida } \\
\text { por três aumentos nos valores dos níveis de } \delta^{18} \mathrm{O} \text { com picos } \\
\text { de }-12,0 \% \text { a } 2.600 \text { anos A.P., }-12,5 \% \text { em } 1.500 \text { anos A.P. e } \\
12,0 \% \text { a } \sim 250 \text { anos, elucidando condições mais secas, } \\
\text { responsáveis pelo desvio da tendência a umidade de longo } \\
\text { prazo; }\end{array}$ & $\begin{array}{l}\text { Kanner et } \\
\text { al. (2013) }\end{array}$ \\
\hline & & $\begin{array}{l}\text { Extremo Norte dos } \\
\text { Andes } \\
\text { (Noroeste da } \\
\text { Colômbia) }\end{array}$ & $\begin{array}{l}\text { Palinológico em } \\
\text { Sequência } \\
\text { Sedimentar } \\
\text { Páramo de Frontino } \\
\left(06^{\circ} 29^{\prime} \mathrm{N} / 76^{\circ} 06^{\prime} \mathrm{W}\right)\end{array}$ & $\begin{array}{c}\text { XRF } \\
{ }^{{ }^{14} \mathrm{C}(\mathrm{AMS})}\end{array}$ & $\begin{array}{l}\text { Pulsos climáticos quentes e secos: } \\
11.410-10.700 / 9.700-6900 / 4.000-2400 \\
\frac{\text { Pulsos climáticos frios e úmidos: }}{10.700-9.700 / 6900 / 4.000}\end{array}$ & $\begin{array}{l}\text { Muñoz et al. } \\
\quad \text { (2017) }\end{array}$ \\
\hline & & $\begin{array}{l}\text { Andes Central } \\
\text { (Norte do Chile) }\end{array}$ & $\begin{array}{l}\text { Palinológico e } \\
\text { estratigráfico em } \\
\text { sedimentos da } \\
\text { Laguna Ceusis } \\
\left(21.04^{\circ} \mathrm{S}, 68.66^{\circ} \mathrm{W}\right)\end{array}$ & $\begin{array}{c}\text { LOI } \\
{ }^{14} \mathrm{C}(\mathrm{AMS})\end{array}$ & $\begin{array}{l}\text { Pulsos climáticos úmidos generalizados: } \\
\qquad .000-3.400 / 2.300-1.900\end{array}$ & $\begin{array}{l}\text { Jara, } \\
\text { Maldonado } \\
\text { e Porras } \\
\text { (2020) }\end{array}$ \\
\hline & & $\begin{array}{l}\text { Deserto do Atacama } \\
\text { adjacente a Cordilheira } \\
\text { de Domeyko } \\
\text { (Norte do Chile) }\end{array}$ & $\begin{array}{l}\text { Isotópico em anéis de } \\
\text { árvore na Bacia } \\
\text { Pampa del } \\
\text { Tamarugal, núcleo } \\
\text { hiperárido do } \\
\text { Deserto de Atacama } \\
\left(19^{\circ} 17^{\prime} \mathrm{S}-21^{\circ} 50^{\circ} \mathrm{S}\right)\end{array}$ & $\begin{array}{c}\delta_{18} \mathrm{O} \\
\delta^{13} \mathrm{C} \\
{ }_{14} \mathrm{C}(\mathrm{AMS})\end{array}$ & $\begin{array}{l}\text { (11.700-8.600) Holoceno Inferior } \\
\text { - Condições mais úmidas e menos variáveis do que as } \\
\text { condições modernas, devido ao aumento dos eventos } \\
\text { pluviais andinos centrais } \\
\quad \begin{array}{l}(8.600-4.900) \text { Holoceno Médio } \\
\text { - Condições mais áridas pontuadas por intervalos úmidos } \\
\text { que vão de décadas a séculos; } \\
\quad \text { (4.900-atual) Holoceno Superior } \\
\text { - Maior disponibilidade de água e frequentes episódios de } \\
\text { inundações por meio de riachos e fluxos rasos de águas } \\
\text { subterrâneas, decorrentes do EPAC (60-200mm anuais); }\end{array}\end{array}$ & $\begin{array}{l}\text { Olson, } \\
\text { Dodda e } \\
\text { Rivera } \\
(2020)\end{array}$ \\
\hline \multirow{4}{*}{\multicolumn{2}{|c|}{ 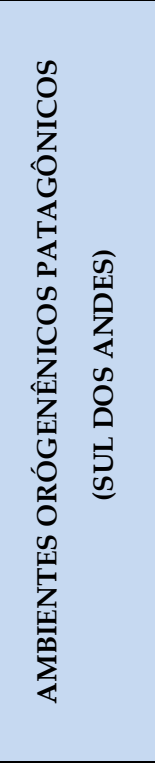 }} & $\begin{array}{c}\text { Setor Norte da } \\
\text { Patagônia Andina } \\
\text { (Centro Sul do Chile) }\end{array}$ & $\begin{array}{l}\text { Palinológico e } \\
\text { estratigráfico e } \\
\text { geoquímico em } \\
\text { sedimentos do } \\
\text { Lago Espejo } \\
\left(43.19^{\circ} \mathrm{S} / 71.86^{\circ} \mathrm{W}\right)\end{array}$ & $\begin{array}{c}\text { LOI } \\
{ }^{14} \text { C(AMS) }\end{array}$ & $\begin{array}{l}\text { 15.400-14.400 (condições temperadas frias e úmidas); } \\
\text { 14.400-12.900 (resfriamento e aumento na precipitação); } \\
\sim 12.900-11.800 \text { (condições temperadas frias e úmidas); } \\
\sim 11.800-10.400 \text { (aumento na atividade de fogo); } \\
\text { 10.400-6.000 (condições quentes e relativamente secas); } \\
\sim 5.500-3.300 \text { (condições mais úmidas); } \\
\sim 3.600-1.000 \text { (aumento na atividade de fogo); }\end{array}$ & $\begin{array}{l}\text { Jara et al. } \\
(2019)\end{array}$ \\
\hline & & $\begin{array}{l}\text { Setor Central da } \\
\text { Patagônia Andina } \\
\text { (Sul da Argentina) }\end{array}$ & $\begin{array}{c}\text { Cosmogênico em } \\
\text { depósitos de } \\
\text { Morainas do Glaciar } \\
\text { Torre } \\
\left(49.3^{\circ} \mathrm{S} / 73.0^{\circ} \mathrm{W}\right) \\
\end{array}$ & ${ }^{10} \mathrm{Be}$ & $\begin{array}{c}\text { Expansão dos Glaciares desde o UMG controladas pelas } \\
\text { tendências de insolação de verão em: } \\
\begin{array}{c}17.600 \pm 900 / 13.500 \pm 500 / 9.700 \pm 400 / 6.900 \pm 200 \\
6.100 \pm 300 / 4.500 \pm 200 / 530 \pm 60\end{array}\end{array}$ & $\begin{array}{l}\text { Reynhout et } \\
\text { al. (2019) }\end{array}$ \\
\hline & & $\begin{array}{l}\text { Sul da Patagônia } \\
\text { (Tierra Del Fuego) } \\
\text { (Sul do Chile) }\end{array}$ & $\begin{array}{l}\text { Cosmogênico em } \\
\text { depósitos de } \\
\text { Morainas (Glaciares } \\
\text { Pingo, Zapata e } \\
\text { Tyndal) }\left(51^{\circ} \mathrm{S}\right) \\
\end{array}$ & $\begin{array}{l}{ }_{14} \mathrm{C} \text { (AMS) } \\
{ }^{10} \mathrm{Be}\end{array}$ & $\begin{array}{c}\text { As geleiras Zapata, Pingo e Tyndall avançaram em: } \\
\leq 3.210 / 700-500(\text { pico em } 600 \pm 70) / \\
400-300(\text { pico em } 340 \pm 20) / 250-150(\text { pico } \leq 190) \\
\text { Avancos glaciais interromperam períodos quentes entre: } \\
\sim 3500-3100 / 900-650 / 350-200 \text { anos. BP }\end{array}$ & $\begin{array}{l}\text { García et al. } \\
\quad(2020)\end{array}$ \\
\hline & & $\begin{array}{c}\text { Extremo sul da } \\
\text { Patagônia } \\
\text { (Tierra Del Fuego) } \\
\text { (Extremo Sul do Chile) }\end{array}$ & $\begin{array}{c}\text { Palinológico em } \\
\text { sedimentos de } \\
\text { turfeira da Ilha Isla } \\
\text { Navarino, Canal } \\
\text { Beagle } \\
\left(54^{\circ} 54^{\prime} \mathrm{S} / 67^{\circ} 57^{\prime} \mathrm{W}\right) \\
\end{array}$ & $\begin{array}{c}\text { LOI } \\
{ }^{14} \text { C(AMS) }\end{array}$ & $\begin{array}{l}\text { 10.700-9.700 (níveis mais elevados de umidade) } \\
\text { 9.700-6.000 (intensa fase mais seca); } \\
\text { 6.000 a atual (tendência para clima mais frio e úmido); } \\
\frac{\text { Fases mais secas que interromperam a tendência para clima }}{\text { mais frio e úmido nos últimos } 6.000 \text { anos A.P.: }} \\
\text { 5.350-4.750 / 4.300-3.300 / 2.600-1.850 / 1.350-1.100 / 550-350 }\end{array}$ & $\begin{array}{l}\text { McCulloch } \\
\text { et al. (2020) }\end{array}$ \\
\hline \multicolumn{2}{|c|}{ 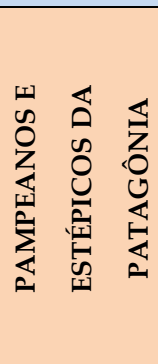 } & $\begin{array}{l}\text { Patagônia Oriental à } \\
\text { leste da Cordilheira dos } \\
\text { Andes } \\
\text { (Centro/Sul da } \\
\text { Argentina) }\end{array}$ & $\begin{array}{l}\text { Palinológicos na } \\
\text { região árida e } \\
\text { semiárida da } \\
\text { Argentina } \\
\left(32^{\circ}-52^{\circ} \mathrm{S}\right)\end{array}$ & ${ }^{14} \mathrm{C}(\mathrm{AMS})$ & $\begin{array}{l}\text { Deslocamento e localização da região árida/semiárida } \\
\text { durante o Holoceno médio: } \\
\text { (8.000-4.000) - limite da região árida/semiárida pampeana e } \\
\text { de estepes da Patagônia foi deslocado para o leste. O } \\
\text { deslocamento máximo para leste ocorreu em } 6.000 \text { anos A.P., } \\
\text { desenvolvendo-se estepes arbustivas em condições } \\
\text { climáticas de máxima seca; } \\
\text { (4000-atual) - período vinculado ao estágio de transição em } \\
\text { direção aos limites atuais da região árida/semiárida } \\
\text { pampeana e de estepes da Patagônia }\end{array}$ & $\begin{array}{l}\text { Mancini et } \\
\text { al. (2005) }\end{array}$ \\
\hline
\end{tabular}


Nos ambientes patagônicos orogênicos, pode-se citar a ocorrência de pulsos climáticos holocênicos determinantes para expansão de glaciares por volta de $9.700 \pm 400$ / $6.900 \pm 200 / 6.100 \pm 300 / 4.500 \pm 200$ / 700-500 / 400-300 e 250-150 anos A.P. (REYNHOUT et al., 2019; GARCÍA et al., 2020); simultâneos a ocorrência de tendência mais úmida no setor norte da patagônia andina (5.500 e 3.300 anos A.P.) e no extremo sul da Patagônia (Tierra Del Fuego), por volta de 10.700-9.700 (JARA et al., 2019; MCCULLOCH et al.; 2020). Enquanto nos ambientes pampeanos e estépicos da patagônia oriental foi observado o deslocamento e localização da região árida/semiárida para leste durante o Holoceno Médio (8.000 e 4.000 anos A.P.), desenvolvendo em boa parte do bioma estepes arbustivas adaptadas às condições climáticas de máxima seca (MANCINI et al., 2005).

5.3.8. Tentativas de generalização para o continente a partir de revisões paleoclimáticas

Revisões teóricas paleoclimáticas sobre proxies já existentes, vinculadas às tentativas de generalização para o continente, também podem ser encontradas nos acervos digitais de repositórios internacionais. Destacam-se as recentes pesquisas que abordaram variabilidades climáticas na América do Sul durante o UMG, Holoceno Médio e Superior (BAKER; FRITZ, 2015; BERMAN; SILVESTRI; TONELLO, 2016, 2018; LÜNING et al., 2019).

Baker e Fritz (2015) realizaram revisão teórica sobre o SMSA, analisando o paleoclima na América do Sul tropical a partir de modelagem climática. Torna-se importante destacar este trabalho, pois os autores questionam um pouco a precisão dos dados de razões isotópicas do oxigênio no carbonato de cálcio de espeleotemas para América do Sul (apresentados nos tópicos anteriores).

Antes de evidenciar mais detalhes sobre a problemática imposta por Baker e Fritz (2015), envolvendo as interpretações das razões de isótopos de ${ }^{18} \mathrm{O}$ na América do Sul, cabe antecipadamente, apresentar alguns destaques inferidos pelos pesquisadores. Baker e Fritz (2015) concordaram com as interpretações realizadas pelos estudos isotópicos do continente sul-americano, relativas às forçantes que causaram e impulsionaram as variações paleoclimáticas do Quaternário. Para os autores, os ciclos climáticos observados no continente, durante o último período glacial, estão de fato intimamente relacionados com as alterações do Atlântico Norte (mudanças de insolação). Os autores também apontam que as atividades de El Niño e La Ninã não são suficientes para explicar a maior parte da variabilidade climática da América do Sul (BAKER; FRITZ, 2015).

Contudo, segundo Baker e Fritz (2015), um aspecto problemático da maioria das publicações sobre registros isotópicos de espeleotema do continente sul-americano, vincula-se ao fato de que dois sinais isotópicos não foram adequadamente considerados na interpretação desses registros. Trata-se da influência da temperatura no fracionamento isotópico carbonato-água da caverna e da variação das razões de ${ }^{18} \mathrm{O}$ da água do mar, em função do sequestro da idade glacial em mantos de gelo continentais de água enriquecida com ${ }^{16} \mathrm{O}$ (BAKER; FRITZ, 2015).

A contabilização destes dois aspectos, de acordo com Baker e Fritz (2015), poderia alterar significativamente as interpretações dos registros de espeleotemas da América do Sul realizadas até então, uma vez que ambos os ajustes tendem a atuar na mesma direção, aumentando a verdadeira amplitude do sinal paleohidrológico datado. Deste modo, para evidenciar tais discrepâncias, os autores apresentaram exemplos de registros isotópicos originais, entre eles o publicado por Cruz et al. (2005), sobrepostos com a correção do fracionamento isotópico dos espeleotemas e, a partir disso, elucidaram por meio de refinamento, a diferença nas interpretações paleoclimáticas implícitas por essas correções indicadas pelo modelo desenvolvido (BAKER; FRITZ, 2015).

Berman, Silvestri e Tonello (2016, 2018), propuseram reconstruções do paleoclima do sul da América do Sul, mediante simulações realizadas pelo modelo PMIP3, a partir de proxies paleoclimáticos existentes. Na publicação de 2016 os autores objetivaram avaliar as diferenças de temperatura e precipitação entre o UMG e período atual no sul da América do Sul, enquanto na publicação de 2018 buscaram avaliar as diferenças entre o clima do UMG com o do Holoceno Médio. 
As simulações demonstraram um resfriamento de $2^{\circ} \mathrm{C}$ a $5^{\circ} \mathrm{C}$ durante o UMG em todo o continente, mais intenso em áreas do sul da Patagônia no inverno (cerca de $8^{\circ} \mathrm{C}$ ). Enquanto as precipitações foram substancialmente menores que a média atual, com reduções de aproximadamente $20 \%$ a 30\% em setores subtropicais e de $40-50 \%$ no extremo sul do continente (BERMAN; SILVESTRI; TONELLO, 2016).

Quanto ao Holoceno Médio, as simulações indicaram temperaturas significativamente mais quentes do que as do UMG em toda América do Sul, com aquecimento mais pronunciado durante o inverno e primavera, condizentes com o aumento da insolação. Com relação às precipitações médias anuais e sazonais, as simulações indicaram diferenças significativas de precipitação entre o Holoceno Médio e UMG, com aumento das chuvas de aproximadamente $32 \%$ a $134 \%$ nos pampas e na patagônia oriental árida durante as quatro estações no Holoceno Médio (BERMAN; SILVESTRI; TONELLO, 2018).

Referente ao Holoceno Superior, destaca-se o estudo realizado por Lüning et al. (2019). Os autores objetivaram analisar o comportamento do clima da América do Sul durante o evento da Anomalia Climática Medieval (ACM), por meio de uma síntese de paleotemperatura, abrangendo os últimos 1.500 anos A.P. a partir da análise de 76 dados multiproxy (terrestres e marinhos). Com base nessa proposta analítica, Lüning et al. (2019) evidenciaram que a maioria das regiões da América do Sul experimentaram condições mais quentes durante a ACM. Entre as principais constatações terrestres, os autores indicaram a ocorrência da expansão da vegetação andina ao longo das encostas; recuo das geleiras; diminuição da durabilidade de gelo na estação fria; aumento da produtividade biológica em sistemas lacustres; e produção de anéis de árvores mais espessos. Para os autores, este período de aquecimento parece ter ocorrido de modo sincronizado e com intensidades comparáveis tanto na América do Sul, quanto no hemisfério norte (LÜNING et al., 2019).

\subsection{Pulsos climáticos identificados na Europa}

Em relação à Europa, Martin et al. (2020) realizaram estudo paleoclimático utilizando nova metodologia a partir de inovador proxie, trata-se do Glicerol Dialquil Glicerol Tetraéteres (GDGT's). Este registro orgânico é oriundo de membranas celulares de bactérias que vivem tanto em ecossistemas terrestres quanto marinhos. Segundo os autores, podem ser encontrados em grande quantidade nos solos e utilizados para reconstruir tendências de temperatura, uma vez que a composição química deste composto é capaz de revelar como a umidade de determinada região se alterou ao longo do tempo.

Nesta linha metodológica, Martin et al. (2020) objetivaram analisar os GDGT's e sinais palinológicos por ${ }^{14} \mathrm{C}$ de um registro sedimentar do lago St Front, no Maciço Central (França), na convergência de influências climáticas do Atlântico Norte e Mediterrâneo. Simultaneamente, os autores objetivaram comparar os novos dados obtidos com outras reconstruções de temperatura regionais e globais, desenvolvidas para e a partir de registros da Europa Ocidental, os quais corroboram com a tendência de uma temperatura máxima no início do Holoceno e ocorrência de ciclos de resfriamento subsequentes até o presente, intercalados por breves retomadas de umidade.

Trata-se do pré-resfriamento holocênico por volta de 8.800-8.500 anos A.P.; evento denominado como 8.2 ka por volta de 8.300-8.100 anos A.P.; resfriamento no Holoceno Médio por volta de 6.000-5.000 anos A.P. (MidHolocene Cooling); optimum climático no Holoceno Médio entre 5.200-4.000 anos A.P. (Mid-Holocene Optimum); evento denominado como Rápida Mudança Climática de 4.2 ka por volta de 4.300-4.100 anos A.P. (Rapid Climate Change); Época Fria da Idade do Ferro entre 2.900-2.400 anos A.P. (Iron Age Cold Epoch); Período de Aquecimento Romano por volta de 2.500-1.600 anos A.P. (Roman Warm Period); Idade das Trevas entre 1.500-1.100 anos A.P. (Dark Ages); e Anomalia Climática Medieval por volta de 1.100-700 anos A.P. (Medieval Climate Anomaly). 


\subsection{Pulsos climáticos identificados na África}

Estudos que envolveram a tentativa de generalização de reconstruções paleoclimáticas durante o Holoceno, para a totalidade do continente africano, são inexistentes em função da elevada variação latitudinal. Na continentalidade da África se alternam regiões climáticas altamente dinâmicas, influenciadas por distintos fenômenos de circulação atmosférica e oceânica, temperadas e tropicais. Fatores que inevitavelmente também estabelecem ritmos e intensidades diferentes como respostas as atuações das pulsações climáticas.

Em função destes aspectos, será destacada a pesquisa de Burrough e Thomas (2013), que objetivou estabelecer reconstruções paleoclimáticas holocênicas a partir de diferentes proxies no centro sul da África. A escolha, referente a este setor da África (centro sul), em detrimento de outras pesquisas realizadas em áreas desérticas ao norte (deserto do Saara), ocorreu em razão da região em questão, possuir características tropicais úmidas e semiáridas semelhantes aos sistemas ambientais no Brasil.

Neste panorama, Burrough e Thomas (2013) analisaram e revisaram registros paleoclimáticos existentes para o centro da África austral e áreas vizinhas afetadas pelos mesmos sistemas climáticos, objetivando compreender os principais controles dos sistemas hidrológicos regionais durante o Holoceno. Posteriormente, os autores apresentaram novos dados, provenientes de datações de dunas barcanas da bacia de Makgadikgadi.

Burrough e Thomas (2013), a partir de interpretações pautadas nas influências climáticas zonais, ligadas à dinâmica da ZCIT e monção da África ocidental, estabeleceram a ocorrência de um período úmido do Holoceno africano entre 14.800 e 5.500 anos A.P., caracterizado por acentuado dinamismo hidrológico com níveis dos lagos mais altos e grandes mudanças no ecossistema/vegetação (esverdeamento do cinturão Sahara / Sahel). No Holoceno Médio e Superior, Burrough e Thomas (2013) identificaram condições mais áridas (dados das dunas barcanas da bacia de Makgadikgadi), com período de relativa estabilidade nos últimos 2.000 anos A.P. Na perspectiva apresentada, Burrough e Thomas (2013) evidenciaram que a atuação dos pulsos climáticos no sul da África Central acarretou mudanças ambientais e ecológicas significativas.

\subsection{Pulsos climáticos identificados na Ásia}

Em função da grande extensão territorial do continente asiático e da multiplicação/difusão de inúmeros trabalhos publicados por pesquisadores chineses e indianos (Quadro 8), torna-se impossível determinar uma tendência de variabilidade espacial uniforme do paleoclima para Ásia durante o Holoceno.

Isso ocorre em razão da elevada variação latitudinal abrangendo zona climática tropical (sudeste Asiático e Ásia meridional), temperada e polar (Ásia oriental, Ásia central, Ásia ocidental e Ásia setentrional); variação longitudinal (úmido a leste e extremamente árido a oeste na zona climática temperada) e variação altitudinal abarcando distintos compartimentos macrogeomorfológicos, desde dobramentos modernos como Himalaia (Monte Everest, $8.848 \mathrm{~m}$ ) até planícies costeiras afetadas pelas monções de verão tropical (Quadro 8).

Tais fatores também impõem diferentes condições climáticas aos sistemas ambientais, submetidos à influência de distintos mecanismos de circulações atmosféricas regionais e locais, resultando em intensidades, durabilidades, ciclicidades, frequências e respostas diferenciadas perante a formação dos processos de formação dos relevos. 
Quadro 8. Tendências paleoclimáticas na Ásia ao longo do Pleistoceno Superior e Holoceno

\begin{tabular}{|c|c|c|c|c|}
\hline Região & Tipo de Registro & Método & Identificação dos Pulsos Climáticos (anos A.P.) & Referências \\
\hline $\begin{array}{l}\text { Ásia Setentrional } \\
\text { Rússia }\end{array}$ & $\begin{array}{l}\text { Depósitos do lago Kyrtyma e } \\
\text { turfa de Oshukovskoe } \\
\text { - índices geoquímicos, taxas de } \\
\text { acumulação e composições dos } \\
\text { macrofósseis vegetais) }\end{array}$ & ${ }^{14} \mathrm{C}$ (AMS) & $\begin{array}{c}\text { 12.000-11.200 (aquecimento); } 11.200-10.100 \text { (resfriamento); } \\
\text { 10.100-9.100 (quente e seco); } 9.100-8.200 \text { (resfriamento); } \\
\text { 8.200-7.100 (quente e seco); } 7.100-5.500 \text { (árido); } \\
\text { 5.500-4.900 (resfriamento); } 4.900-3.700 \text { (quente e úmido); } \\
\text { 3.500-3.300 (seco); 3.200-2.800-0 (umidificação) }\end{array}$ & $\begin{array}{l}\text { Ryabogina } \\
\text { et al. }(2019)\end{array}$ \\
\hline $\begin{array}{l}\text { Ásia Setentrional } \\
\text { Rússia } \\
\text { Nordeste da Sibéria } \\
\end{array}$ & $\begin{array}{l}\text { Proxies bióticos e abióticos de } \\
\text { Núcleos de sedimentos do } \\
\text { Lago Kyutyunda }\end{array}$ & $\begin{array}{l}{ }^{14} \mathrm{C}(\mathrm{AMS}) \\
{ }^{210} \mathrm{~Pb} \\
\delta^{13} \mathrm{C}, \mathrm{XRD} \\
\end{array}$ & $\begin{array}{c}\text { 13.500-8.900 (cobertura sazonal prolongada de gelo com média } \\
\text { de temperatura no verão de } 15,5^{\circ} \mathrm{C} \text { ); } 8.900-4.500 \text { e } 4.500-0 \\
\text { (encurtamento da cobertura sazonal de gelo) }\end{array}$ & $\begin{array}{l}\text { Biskaborn et } \\
\text { al. (2016) }\end{array}$ \\
\hline $\begin{array}{c}\text { Ásia Central } \\
\text { Noroeste da China }\end{array}$ & $\begin{array}{l}\text { Palinológico de turfa nas } \\
\text { Montanhas Xinjiang-Altai }\end{array}$ & ${ }^{14} \mathrm{C}$ & $\begin{array}{l}\text { Até } 8.000 \text { (frio e seco); } 8.000-5.500 \text { (quente e úmido); } 5.500-4.000 \\
\text { (frio e seco); } 4.000-1.000 \text { (frio e úmido); } 1000-0 \text { (quente e seco) }\end{array}$ & $\begin{array}{c}\text { Zhang et al. } \\
(2018)\end{array}$ \\
\hline $\begin{array}{c}\text { Ásia Central } \\
\text { Cazaquistão/Uzbequistão }\end{array}$ & $\begin{array}{l}\text { Palinológico em núcleo de } \\
\text { sedimentos da Baía de } \\
\text { Chernyshov, Mar de Aral }\end{array}$ & ${ }^{14} \mathrm{C}(\mathrm{AMS})$ & $\begin{array}{l}\frac{\text { Expansão de veget. xérica dominada de elementos das estepes }}{2.020-1.620 ; 1.120-870 ; 520-370 \text { (Condições frias e áridas) }} \\
\frac{\text { Expansão da veget. das estepes c/ plantas de condições Úmidas }}{1.620-1.120 ; 870-570 \text { (condições mais úmidas) }}\end{array}$ & $\begin{array}{l}\text { Sorrel et al. } \\
\quad(2007)\end{array}$ \\
\hline $\begin{array}{l}\text { Ásia Ocidental } \\
\text { Sudeste do Irã }\end{array}$ & $\begin{array}{c}\text { Núcleo de Sedimentos } \\
\text { - tamanho dos grãos, matéria } \\
\text { orgânica e teor de carbonato de } \\
\text { cálcio, isótopos estáveis }\end{array}$ & $\begin{array}{l}{ }^{14} \mathrm{C}, \text { LOI } \\
\text { LA-950 } \\
\text { XRD } \\
\delta^{13} \mathrm{C}, \delta^{18} \mathrm{O}\end{array}$ & $\begin{array}{l}\text { 19.000-16.800 (árido); } 14000-13200 \text { (úmido); } 13.200-11.400 \text { (seco, } \\
\text { ambiente erosivo); } 11.400-9.600 \text { (úmido com alta precipitação) } \\
\text { 9.400-6.300 (seco); } 5000-4700 \text { (úmido); } 4.500-4.300 \text { (seco); 4300-0 } \\
\text { (condições áridas) }\end{array}$ & $\begin{array}{l}\text { Vaezi et al. } \\
\qquad(2019)\end{array}$ \\
\hline $\begin{array}{l}\text { Ásia Ocidental } \\
\text { Mar Mediterrâneo } \\
\text { Delta do Nilo, litoral de } \\
\text { Israel }\end{array}$ & $\begin{array}{l}\text { Sedimentológicos, } \\
\text { geoquímicos, isótopos estáveis, } \\
\text { palinológicos, moluscos, } \\
\text { equinodermos e Foraminíferos }\end{array}$ & ${ }^{14} \mathrm{C}$ (AMS) & $\begin{array}{l}4.500-3.800 \text { (condição árida com pico em } 4280 \text { ) } \\
3.600 \text { (quente e seco) } \\
3.500 \text { - } 3.000 \text { (quente e úmido) } \\
2.900 \text { (quente e seco) }\end{array}$ & $\begin{array}{l}\text { Avnaim- } \\
\text { Katav et al. } \\
\quad(2019)\end{array}$ \\
\hline $\begin{array}{l}\text { Ásia Meridional } \\
\text { Extremo Norte da Índia }\end{array}$ & $\begin{array}{l}\text { Sedimentos dos Terraços } \\
\text { Fluviais do rio Satluj (Índia) }\end{array}$ & OSL/SAR & $\begin{array}{l}\text { 13.400-10.400 (condição mais fria e menos úmida); } 8.300-3.600 \\
\text { (condição mais fria e menos úmida); } 2.200-1.400 \text { (condição mais } \\
\text { fria e menos úmida); } 1.400 \text { (condição mais fria e menos úmida) }\end{array}$ & $\begin{array}{l}\text { Sharma et } \\
\text { al. (2017) }\end{array}$ \\
\hline $\begin{array}{l}\text { Ásia Meridional } \\
\text { Índia }\end{array}$ & $\begin{array}{l}76 \text { proxies de } 8 \text { classes de lagos } \\
\text { da Índia classificados pelo } \\
\text { contexto climático e } \\
\text { topográfico regional }\end{array}$ & $\begin{array}{l}{ }^{14} \mathrm{C}(\mathrm{AMS}) \\
\text { OSL/SAR } \\
\text { IRSL/SAR } \\
\text { BLSL/SAR }\end{array}$ & $\begin{array}{l}\text { 9.000-5.000 (quente e úmido / pico das monções) } \\
5.000-4.000 \text { (condições moderadamente secas) } \\
\text { Após } 4.000 \text { tendência de aridez em toda Índia }\end{array}$ & $\begin{array}{l}\text { Misra, } \\
\text { Tandon e } \\
\text { Sinha } \\
(2019)\end{array}$ \\
\hline $\begin{array}{l}\text { Ásia Oriental } \\
\text { Taiwan }\end{array}$ & $\begin{array}{l}\text { Palinológico em sequência de } \\
\text { pólen subalpino a partir de } \\
\text { depósitos de turfeiras no } \\
\text { centro de Taiwan } \\
\text { Núcleos de Gelo }\end{array}$ & ${ }^{14} \mathrm{C}$ & $\begin{array}{l}\text { Mudança para tipo de floresta mais fria: } \\
\text { 11.200-11.000 (de floresta subtropical para temperada) } \\
9.600-9.400 \text { (de floresta subtropical para temperada quente) } \\
7.600-7.100 \text { (de floresta subtropical para temperada) } \\
5.600-5.000 \text { (de floresta subtropical para temperada) } \\
4.200-4.000 \text { (de floresta subtropical para temperada quente) } \\
\text { 3.500 (de floresta subtropical para temperada quente) } \\
\quad \text { Mudança para tipo de floresta mais quente: } \\
11.000-10.400 \text { (de floresta temperada para temperada quente) } \\
10.200-9.500 \text { (de floresta temperada quente para subtropical) } \\
9.500-8.500 \text { (pico dos esporos) } \\
7.900 \text { (de floresta temperada quente para subtropical) } \\
7.100-6.800 \text { (de floresta subtropical para tropical) } \\
6.200-5.800 \text { (floresta tropical / optimum climático) } \\
4.800-4.700 \text { (de floresta temperada quente para subtropical) } \\
\text { 3.900 (de floresta temperada quente para subtropical) }\end{array}$ & $\begin{array}{l}\text { Liew, Lee } \\
\text { e Kuo } \\
(2006)\end{array}$ \\
\hline $\begin{array}{l}\text { Ásia Oriental } \\
\text { Leste da China } \\
\text { Shaanxi - Weinan }\end{array}$ & $\begin{array}{c}\text { Depósito Loess no Platô da } \\
\text { China }\end{array}$ & OSL/SAR & $\begin{array}{l}\text { 3.200-2.500 / Neoglacial Period (frio) } \\
\text { 2.500-1.900 / Roman Warm Period inicial (quente e úmido) } \\
\text { 1.900-1.650 / Roman Warm Period médio (frio) } \\
\text { 1.650-1.300 / Roman Warm Period tardio (quente e úmido) } \\
\text { 1.300 - 1.100 / Dark Age Cold Period (frio) } \\
\text { 1.100-700 / Medieval Climate Anomaly (quente e úmido) } \\
\text { 700-400 / Little Ice Age inicial (frio) } \\
\text { 400-250 / Little Ice Age tardio (frio fraco) } \\
\text { 250-atual (quente com retomada de umidade) }\end{array}$ & $\begin{array}{l}\text { Kang et al. } \\
\text { (2018) }\end{array}$ \\
\hline $\begin{array}{l}\text { Sudeste Asiático } \\
\text { (Vietnã) }\end{array}$ & $\begin{array}{l}\text { Palinológicos em núcleos de } \\
\text { sedimentos do delta Song } \\
\text { Hong do rio Vermelho na zona } \\
\text { subtropical da Ásia }\end{array}$ & ${ }^{14} \mathrm{C}$ (AMS) & $\begin{array}{l}\text { 5.340-4.530 / Optimum climático (quente e úmido) } \\
\text { 4.530-3.340 /Neoglacial Period (clima frio e úmido) } \\
\text { 3.340-2.100 (clima quente e seco) } \\
\text { 2.100-1.540 (clima frio e úmido) } \\
\text { 1.540-620 / Medieval Warm Period (clima quente e seco) } \\
\text { 620-130 / LIA (clima frio e úmido); 130-0 (clima quente atual) }\end{array}$ & $\begin{array}{l}\text { Li et al. } \\
(2006)\end{array}$ \\
\hline $\begin{array}{l}\text { Sudeste Asiático } \\
\text { Vietnã, Camboja, } \\
\text { Tailândia, Malásia e } \\
\text { Indonésia }\end{array}$ & $\begin{array}{l}\text { Elevação e idades de } 546 \\
\text { registros do nível relativo do } \\
\text { mar vinculados a corais, } \\
\text { depósitos deltaicos, estuarinos } \\
\text { e de manguezais, rochas de } \\
\text { praia e entalhes de marés }\end{array}$ & ${ }^{14} \mathrm{C}$ & $\begin{array}{l}\text { De modo geral os dados convergem para rápida transgressão } \\
\text { marinha após UMG prolongando-se ao Holoceno Inferior } \\
\text { (aquecimento), atingindo nível semelhante ao atual e superior a } \\
\text { ele durante o Holoceno Médio (optimum climático) com } \\
\text { posterior regressão marinha até o nível atual durante o Holoceno } \\
\text { Superior (condições atuais). }\end{array}$ & $\begin{array}{l}\text { Mann et al. } \\
\text { (2019) }\end{array}$ \\
\hline
\end{tabular}


Neste sentido, foram referenciadas pesquisas realizadas em regiões extremamente áridas como o Oriente Médio (Irã e Israel); relativamente áridas na Ásia Central (Cazaquistão e Uzbequistão); extremamente úmidas próximas a linha do Equador, sob influências das monções de verão, como sul da Índia e ilhas do Sudeste Asiático (Vietnã, Camboja, Tailândia, Malásia e Indonésia) e polares como a Sibéria na Rússia, sob influência da cobertura sazonal prolongada de gelo (LI et al., 2006; LIEW; LEE; KUO, 2006; SORREL et al., 2007; BISKABORN et al., 2016; SHARMA et al., 2017; ZHANG et al., 2018; KANG et al., 2018; AVNAIM-KATAV et al., 2019; MANN et al., 2019; MISRA; TANDON; SINHA, 2019; RYABOGINA et al., 2019; VAEZI et al., 2019).

\subsection{Pulsos climáticos identificados na Antática}

O comportamento do clima no Holoceno também foi estudado na Antártica, destaca-se a pesquisa de Nielsen, Koc, e Crosta (2004). Os autores buscaram compreender as causas da variabilidade climática holocênica no setor Atlântico do Oceano Antártico a partir de problemática inicial pautada na investigação dos mecanismos forçantes (gênese): o clima durante o Holoceno no setor atlântico do oceano Antártico foi controlado por insolação (forçante externa) ou circulação oceânica (forçante interna)?

Nielsen, Koç, e Crosta (2004) alertaram para a dificuldade de reconstituições paleoclimáticas holocênicas na Antártica em virtude da falta de registros oceânicos datados, poucos quando comparados com outros continentes. Tais registros, segundo os autores, se restringem aos núcleos de gelo antártico que geralmente apresentam pouca variabilidade climática durante o Holoceno, exibindo normalmente um Holoceno Inferior quente seguido de resfriamento abrupto entre aproximadamente 5.500 e 5.000 anos A.P. De acordo com Nielsen, Koc, e Crosta (2004) raros são os dados provenientes da corrente circumpolar Antártica.

Objetivando sanar esta carência, Nielsen, Koc, e Crosta (2004) realizaram datação por espectrometria de massas, com aceleradores $\left({ }^{14} \mathrm{C}\right)$, em registro vinculado à assembleia de diatomáceas, situadas próximo a frente polar da corrente circumpolar Antártica, a 3.700m de profundidade (amostra TN057-17). Simultaneamente, Nielsen, Koc, e Crosta (2004) objetivaram correlacionar os resultados geocronológicos, vinculados às estimativas quantitativas da temperatura da superfície do mar no verão (diatomáceas), com registros já existentes em gelo antártico obtidos por outros pesquisadores.

O registro TN057-17 apresentou boa correlação com os núcleos de gelo antártico, evidenciando optimum climático entre 12.500 e 6.200 anos A.P, seguido por tendência de arrefecimento de $4^{\circ} \mathrm{C}$ caracterizada pela atuação de pulsos climáticos graduais (sem resfriamento neoglacial abrupto) e subsequente aquecimento holocênico tardio sem precedentes, com início por volta de 4.000 anos A.P. Segundo Nielsen, Koç, e Crosta (2004), o fator de força dominante das variações climáticas holocênicas na Antártica, parece ter sido a insolação processional, responsável por alterar a temperatura da superfície do mar e consequentemente as mudanças na circulação oceânica no início do Holoceno.

\subsection{Pulsos climáticos identificados na Oceania}

Em relação à atuação dos pulsos climáticos na Oceania, evidencia-se neste momento a pesquisa de Reeves et al. (2013), desenvolvida na Austrália. A escolha deste estudo justifica-se pela dimensão territorial do país, a qual apresenta-se por ser a mais representativa para a reconstrução paleoclimática a partir de um cenário generalizado para todo o continente. A escolha também se justifica pela pesquisa homônima ter realizado análise de registros bem distribuídos espacialmente, quando comparada com outros estudos de abordagens paleoclimáticas similares, porém com investigação de registros localizados. Assim, os resultados de Reeves et al. (2013) expressaram uma tendência continental das variações paleoclimáticas durante o Holoceno, em detrimento de variações locais e regionais. 
Nesta perspectiva, Reeves et al. (2013) objetivaram realizar uma síntese de registros climáticos marinhos e terrestres, combinando descobertas de zonas temperadas, tropicais e áridas, para identificar uma resposta complexa dos proxies climáticos perante desenvolvimento de cenários correlacionados às variabilidades das condições atmosféricas ao longo dos últimos 35.000 anos A.P.

Deste modo, a partir da adoção metodológica pautada em abordagem espacial, Reeves et al. (2013) procuraram discernir os padrões de mudança em todo o continente. A análise identificou eventos importantes, correlacionados aos conceitos estabelecidos na introdução desta pesquisa, reconhecidos pela literatura paleoclimática ao longo do Pleistoceno Superior e Holoceno.

Trata-se da oscilação climática vinculada ao MIS 3, entre 35.000 e 32.000 anos A.P.; mudança climática referente ao último máximo glacial entre 32.000 e 18.000 anos A.P. e aquecimento deglacial subsequente (18.000 a 12.000 anos A.P.) em direção ao optimum climático do Holoceno por volta de 5.000 anos A.P.; bem como pulsos climáticos holocênicos que ocorreram ao longo do Holoceno Inferior (12.000 a 8.000 anos A.P.), Holoceno Médio (8.000 a 5.000 anos A.P.) e Holoceno Superior (5.000 a 0 anos A.P.).

Reeves et al. (2013) reconheceram no Holoceno um período de considerável variabilidade climática, que no caso da Oceania está diretamente associada à alteração da dinâmica da monção nos trópicos, controlada e alterada por forçantes atreladas ao momento sazonal da insolação, ao conteúdo de gases de efeito estufa na atmosfera, ao aumento do nível do mar e as próprias mudanças na circulação oceânica e atmosférica.

\subsection{Ciclos de resfriamentos globais no Holoceno}

Como visto até o momento, embora não estejam totalmente definidas as variáveis responsáveis pelas alterações climáticas e ambientais ao longo do Holoceno, aspectos que envolvem insolação solar devido às mudanças orbitais para áreas específicas no Hemisfério Norte e Hemisfério Sul durante o verão (MILANKOVITCH, 1920; WERNER; WOLFF, 2007; SHEVENELL; INGALLS; DOMACK, 2007); liberação de sulfato em função de atividades vulcânicas durante os últimos 6.000 anos (GAO; ROBOCK; AMMANN, 2008; WANNER et al., 2008); variações na atividade solar (CHAPMAN; SHACKLETON, 2000; VIAU et al., 2002; GUPTA; ANDERSON; OVERPECK, 2003; HONG et al., 2003; KRIVOVA; SOLANKI, 2008; STEINHILBER; BEER; FRÖHLICH, 2009; GRAY et al., 2010); aumento da concentração de CO2 (ENTING, 1987; STOTT; TIMMERMANN; THUNELL, 2007); mudanças na temperatura da superfície do mar e na circulação termohalina (BIANCHI; MCCAVE, 1999; JENNINGS et al., 2002) vêm sendo consideradas por muitos autores, como a pesquisa de Wanner et al. (2011), referência para compreensão do paleoclima no Holoceno.

Baseado nos ciclos de Bond et al. (1997, 2001), Wanner et al. (2011) definiram seis eventos de resfriamento globais ao longo do Holoceno (450-650, 1.450-1.650, 2.600-2.800, 4.600-4.800, 6.200-6.400, 8.100-8.300 anos A.P.), responsáveis por interromperem períodos mais quentes e úmidos. Para desenvolverem tais proposições, Wanner et al. (2011) adotaram metodologia baseada em revisões bibliográficas de pesquisas científicas que abordaram as variáveis responsáveis pelas alterações ambientais holocênicas. Desse modo, os autores sintetizaram importantes dados geocronológicos, distribuídos em todos os continentes, adquiridos junto a repositórios de dados oficiais. Assim, a partir de diversas datações absolutas direcionadas para reconstrução do avanço de geleiras, análise de séries temporais de temperatura, umidade e precipitação, determinaram a ocorrência dos eventos paleoclimáticos em questão.

Entre estes seis eventos de resfriamentos globais holocênicos, os dois mais recentes já foram bem estudados. Trata-se dos episódios denominados de Dark Age Cold Period (1.500 e 1.050 anos A.P.) e Little Ice Age (450 a 100 anos A.P.). Destacam-se as pesquisas realizadas por Thompson et al. (1986), Blackford e Chambers (1991), Bond et al. (1997), Cronin et al. (2003), Loso (2009), Ljungqvist (2010), Graham et al. (2011) e Helama, Jones e Briffa (2017). 


\section{Considerações Finais}

Verifica-se, com base na literatura, intensa dinâmica climática ao longo do Quaternário. As pesquisas evidenciadas trouxeram contribuições inegáveis em relação à ampliação do conhecimento para elaboração de teorias evolutivas da paisagem, construção de base de dados geocronológicos (idades), renovação de conhecimentos em relação a eventos paleoclimáticos e compreensão do comportamento de diversos componentes ambientais, diante de tais oscilações e seus mecanismos de controle.

Nota-se aperfeiçoamento da identificação de eventos paleoclimáticos condizente com refinamentos metodológicos impulsionados por avanços tecnológicos. Nesta perspectiva tornou-se possível identificar, distinguir e conceitualizar três grandes grupos de eventos climáticos baseados na durabilidade e ciclicidade temporal de determinada tendência dos fenômenos atmosféricos.

Este fato torna-se claro ao constatar que as técnicas mais antigas e menos precisas, pautadas em datações relativas por correlações estratigráficas, foram capazes de determinar apenas eventos de maior duração e abrangência espacial (mudanças climáticas), enquanto as mais recentes proporcionaram a identificação de eventos de média (oscilações climáticas) e curta abrangência temporal (pulsações climáticas).

Assim, observa-se que o advento de datações absolutas de razões de isótopos de oxigênio $\left({ }^{16} \mathrm{O},{ }^{18} \mathrm{O}\right)$ em foraminíferos, núcleos de gelo e espeleotemas cársticos, proporcionaram a identificação de oscilações climáticas situadas temporalmente entre picos extremos de estágios glaciais e interglaciais bem definidos (mudanças climáticas), as quais passaram despercebidas pelos métodos antigos de correlação estratigráfica. A revolução de isótopos cosmogênicos também ofereceu mais consistência científica, possibilitando a reconstituição de variações climáticas em períodos mais antigos da história geológica, remontando ciclos dos últimos 5.3 milhões de anos A.P.

Do mesmo modo, a constante evolução de softwares especializados e algoritmos de correlações gráficas automatizados, para mensuração de aspectos que envolvem insolação solar devido mudanças orbitais; liberação de sulfato em função de atividades vulcânicas; aumento da concentração de $\mathrm{CO}_{2}$; alteração da circulação termohalina; modificações das temperaturas da superfície do mar; variações na temperatura do ar e mudanças nos volumes precipitados, obtidos a partir de datações em diferentes proxies, proporcionaram novas descobertas científicas vinculadas às reconstruções paleoclimáticas. Estes avanços, possibilitaram a identificação de eventos de curta duração ocorridos em escala de tempo recente (pulsações climáticas). Tais pulsos são mais conhecidos no Holoceno, em razão dos registros estarem mais preservados.

Torna-se imprescindível salientar que as tendências destacadas nessa pesquisa, não ocorreram de modo sincronizado ao longo de todo globo terrestre. Esta afirmação fica nítida ao se comparar os períodos de ocorrência e características dos pulsos climáticos evidenciados para todos os continentes, pois por mais que haja uma tendência generalizada dos fenômenos climáticos, as características específicas de cada sistema ambiental, atreladas principalmente à variação latitudinal, longitudinal e altitudinal, impõem ritmos e intensidades diferentes, impedindo a uniformização das condições climáticas no planeta.

Nota-se a coexistência de diferentes tipos de eventos, os singulares e irreversíveis, daqueles que são reversíveis (porém, lentos) e aqueles que são repetitivos e partem de uma tendência contínua (uniformes ou não uniformes), dos quais deve haver uma distinção a partir dos métodos empregados e evidências encontradas perante os testemunhos/registros no tempo e espaço.

A partir das evidências contidas neste esforço de revisão bibliográfica, torna-se importante pensar como os processos esculturais e deposicionais se comportaram no decorrer das tendências inferidas, esculpindo diversas formas de relevo nas mais distintas áreas do globo. Espera-se que o presente manuscrito, redigido em português, possa proporcionar grande alcance entre a comunidade geomorfológica brasileira. Acredita-se que o melhor 
reconhecimento das tendências paleoclimáticas e avanços científicos na área, possa estimular discussões mais robustas sobre a investigação da gênese dos relevos esculturais brasileiros.

\section{Contribuições dos Autores:}

Desenvolvimento e distinção dos conceitos de mudanças, oscilações e pulsações climáticas, Archimedes Perez Filho e Felipe Gomes Rubira; seleção de bibliografias e tabulação dos dados, Felipe Gomes Rubira; estruturação e redação do artigo, Felipe Gomes Rubira; aquisição de financiamento, Archimedes Perez Filho. Todos os autores leram e concordaram com a versão publicada do manuscrito.

Financiamento: Esta pesquisa foi financiada pela Fundação de Amparo à Pesquisa do Estado de São Paulo, número de bolsa 2016/08944-6.

Agradecimentos: Externamos nossos agradecimentos à FAPESP (Fundação de Amparo à Pesquisa do Estado de São Paulo), pelo fomento financeiro da pesquisa por meio dos Processos: 2016/05327-6, 2016/08944-6.

Conflito de Interesse: Os autores declaram não haver conflito de interesse.

\section{Referências}

1. AB'SABER, A. N. Sertões e sertanejos: uma geografia humana sofrida. Estudos avançados, v.13, n.36, p.7-59, 1999.

2. ALIZADEH, K.; COHEN, M.; BEHLING, H. Origin and dynamics of the northern South American coastal savanna belt during the Holocene e the role of climate, sea-level, fire and humans. Quaternary Science Reviews, v.122, p.51-62, 2015. DOI. 10.1016/j.quascirev.2015.05.009.

3. APAÉSTEGUI, J.; CRUZ, F. W.; SIFEDDINE, A.; VUILLE, M.; ESPINOZA, J. C.; GUYOT, J. L.; KHODRI, M.; STRIKIS, N.; SANTOS, R. V.; CHENG, H.; EDWARDS, L.; CARVALHO, E.; SANTINI, W. Hydroclimate variability of the northwestern Amazon Basin near the Andean foothills of Peru related to the South American Monsoon System during the last 1600 years. Climate of the Past, v.10, n.6, p.1967-1981, 2014. DOI. 10.5194/cp-10-1967-2014. 4. ASHTON, N.; LEWIS, S. G.; PARFITT, S. A.; PENKMAN, K. E. H.; COOPE, G. R. New evidence for complex climate change in MIS 11 from Hoxne, Suffolk, UK. Quaternary Science Reviews, v. 27, n. 7-8, p.652-668, 2008. DOI. 10.1016/j.quascirev.2008.01.003.

5. AVNAIM-KATAV, S.; ALMOGI-LABIN, A.; SCHNEIDER-MOR, A.; CROUVI, O.; BURKE, A. A.; KREMENETSKI, K. V.; MACDONALD, A. G. M. A multi-proxy shallow marine record for Mid-to-Late Holocene climate variability, Thera eruptions and cultural change in the Eastern Mediterranean. Quaternary Science Reviews, v.204, p.133-148, 2019. DOI. 10.1016/j.quascirev.2018.12.001.

6.AZEVEDO, V.; STRÍKIS, N. M.; SANTOS, R. A.; SOUZA, J. G.; AMPUERO, A.; CRUZ, F. W.; OLIVEIRA, P.; IRIARTE, J.; STUMPF, C. F.; VUILLE, M.; MENDES, V. R.; CHENG, H.; EDWARDS, L. R. Medieval Climate Variability in the eastern Amazon-Cerrado regions and its archeological implications. Scientific Reports, v.9, 20306, 2019. DOI. 10.1038/s41598-019-56852-7.

7. BAKER, P. A.; FRITZ, S. C. Nature and causes of Quaternary climate variation of tropical South America. Quaternary Science Reviews, v.124, p.31-47, 2015. DOI. 10.1016/j.quascirev.2015.06.011.

8. BECKER, B. F.; SILVA-CAMINHA, S. A. F.; GUERREIRO, R. L.; OLIVEIRA, E. J.; D'APOLITO, C.; ASSINE, M. L. Late Holocene palynology of a saline lake in the Pantanal of Nhecolândia, Brazil. Palynology, v.42, n.4, p.457465, 2018. DOI. 10.1080/01916122.2017.1386843.

9. BEHLING, H. South and southeast Brazilian grasslands during Late Quaternary times: a synthesis. Palaeogeography, Palaeoclimatology, Palaeoecology, v.177, n.1-2, p.19-27, 2002. DOI. 10.1016/S00310182(01)00349-2.

10. BEHLING, H.; PILLAR, V. D.; BAUERMANN, S. G. Late Quaternary grassland (Campos), gallery forest, fire and climate dynamics, studied by pollen, charcoal and multivariate analysis of the São Francisco de Assis core in Revista Brasileira de Geomorfologia. 2021, v. 22, n. 4; (Out-Dez) DOI: 10.20502/rbg.v22i4.1895 http://www.lsie.unb.br/rbg/ 
western Rio Grande do Sul (southern Brazil). Review of Palaeobotany and Palynology, v.133, n.3-4, p.235-248, 2005. DOI. 10.1016/j.revpalbo.2004.10.004.

11. BELL, F. G. The geotechnical properties of some till deposits occurring along the coastal areas of eastern England. Engineering Geology, v. 63, n.1-2, p.49-68, 2002. DOI. 10.1016/S0013-7952(01)00068-0.

12. BERGER, W. H.; WEFER, G. On the dynamics of the ice ages: stage-11 paradox, mid-Brunhes climate shift, and 100-ky cycle. American Geophysical Union Monograph. v.137, p. 41-59, 2003. DOI. doi.org/10.1029/137GM04.

13. BERMAN, A. L.; SILVESTRI, G. E.; TONELLO, M. S. Differences between Last Glacial Maximum and presentday temperature and precipitation in southern South America. Quaternary Science Reviews, v.150, p.221-233, 2016. DOI. 10.1016/j.quascirev.2016.08.025.

14. BERMAN, A. L.; SILVESTRI, G. E.; TONELLO, M. S. On the differences between Last Glacial Maximum and Mid-Holocene climates in southern South America simulated by PMIP3 models. Quaternary Science Reviews, v.185, p.113-121, 2018. DOI. 10.1016/j.quascirev.2018.02.003.

15. BIANCHI, G. G.; MCCAVE, I. N. Holocene periodicity in North Atlantic climate and deep ocean flow south of Iceland. Nature, v.397, p.515-517, 1999. DOI. 10.1038/17362.

16. BIGARELLA, J. J.; MOUSINHO, M. M.; SILVA, J. X. Processes and environments of the Brazilian Quaternary. Curitiba: Imprensa Universitária do Paraná, Universidade Federal Paraná, 1965, 69p.

17. BISKABORN, B. K.; SUBETTO, D.A; SAVELIEVA, L. A.; VAKHRAMEEVA, P. S.; HANSCHE, A.; HERZSCHUH, U.; KLEMM, J.; HEINECKE, L.; PESTRYAKOVA, L.A.; MEYER, H.; KUHN, G.; DIEKMANN, B. Late Quaternary vegetation and lake system dynamics in northeastern Siberia: Implications for seasonal climate variability. Quaternary Science Reviews, v.147, p.406-421, 2016. DOI. 10.1016/j.quascirev.2015.08.014.

18. BLACKFORD, J. J.; CHAMBERS, F. M. Proxy records of climate from blanket mires: Evidence for a Dark Age (1400 BP) climatic deterioration in the British Isles. The Holocene, v.1, n.1, p.63-67, 1991. DOI. 10.1177/095968369100100108.

19. BOND, G.; SHOWERS, W.; CHESEBY, M.; LOTTI, R.; ALMASI, P.; MENOCAL, P.; PRIORE, P.; CULLEN, H.; HAJDAS, I.; BONANI, G. A pervasive millennial-scale cycle in the North Atlantic Holocene and glacial climates. Science, v.278, n. 5341, p.1257-1266, 1997. DOI. 10.1126 / science.278.5341.125.

20. BOND, G.; KROMER, B.; BEER, L.; MUSCHELER, R.; EVANS, M. N.; SHOWERS, W.; HOFFMANN, S.; LOTTIBOND, R.; HAJDAS, I.; BONANI, G. Persistent solar influence on North Atlantic climate during the Holocene. Science, v.294, n.5549, p.2130-2136, 2001. DOI. 10.1126 / science.1065680.

21. BURROUGH, S. L.; THOMAS, D. S. G. Central southern Africa at the time of the African Humid Period: a new analysis of Holocene palaeoenvironmental and palaeoclimate data. Quaternary Science Reviews, v.80, p.29-46, 2013. DOI. 10.1016/j.quascirev.2013.08.001.

22. BORSATO, V. A.; MENDONÇA, F. A. Participação da massa polar atlântica na dinâmica dos sistemas atmosféricos no centro sul do Brasil. Mercator, v.14, n.1, p.113-130, 2015. DOI. 10.4215/RM2015.1401.0008.

23. BUSSELL, M. R.; PILLANS, B. Vegetational and climatic history during Oxygen Isotope Stage 9, Wanganui District, New Zealand, and correlation of the Fordell Ash. Journal of the Royal Society of New Zealand, v. 22, n.1, p.41-60. DOI. 10.1080/03036758.1992.10420816.

24. CARDOSO NETA, L.; SILVA, M. V. Análise de um Sistema Convectivo no Sul do Brasil utilizando índices de instabilidade. Ciência e Natura, v.38, n.1, 2016, p.404-412, 2016. DOI. 10.5902/2179-460X14853.

25. CARDOZO, A. B.; REBOITA, M. S.; GARCIA, S. R. Climatologia de frentes frias na América do Sul e sua relação com o modo anular sul. Revista Brasileira de Climatologia, v.17, p.9-26, 2015. DOI. 10.5380/abclima.v17i0.40124. 
26. CASSINO, R. F.; LEDRU, M.; SANTOS, R. A.; FAVIER, C. Vegetation and fire variability in the central Cerrados (Brazil) during the Pleistocene-Holocene transition was influenced by oscillations in the SASM boundary belt. Quaternary Science Reviews, v.232, 106209, 2020. DOI. 10.1016/j.quascirev.2020.106209.

27. CHAPMAN, M. R.; SHACKLETON, N. J. Evidence of 550-year and 1000-year cyclicities in North Atlantic circulation patterns during the Holocene. Holocene, v.10, n.3, p.287-291, 2000. DOI. 10.1191/095968300671253196. 28. CONNECTICUT DEPARTMENT OF ENERGY AND ENVIRONMENTAL PROTECTION. Overview of the Ground Water Flow System in Connecticut, 2021. Disponível em: https://www.ct.gov/deep/cwp/view.asp?a=2685\&q=322262\&deepNav_GID=1654. Acesso em: 04/02/2021

29. CRONIN, T. M.; DWYER, G. S.; KAMIYA, T.; SCHWEDE, S.; WILLARD, D. A. Medieval Warm Period, Little Ice Age and 20th century temperature variability from Chesapeake Bay. Global and Planetary Change, v. 36, n.12, p. 17-29, 2003. DOI. 10.1016/S0921-8181(02)00161-3.

30. CRUZ, F. W.; BURNS, S. J.; KARMANN, I.; SHARP, W. D.; VUILLE, M.; CARDOSO, A. O.; FERRARI, J. A.; DIAS, P. L. S.; VIANA JÚNIOR, O. Insolation-driven changes in atmospheric circulation over the past 116,000 years in subtropical Brazil. Nature, v. 434, p.63-66, 2005. DOI. 10.1038/nature03365.

31. CRUZ, F. W.; VUILLE, M.; BURNS, S. J.; WANG, X.; CHENG, H.; WERNER, M.; EDWARDS, R. L.; KARMANN, I.; AULER, A. S.; NGUYEN, H. Orbitally driven east-west antiphasing of South American precipitation. Nature Geoscience, v.2, p.210-214, 2009. DOI. 10.1038/ngeo444.

32. CUÑA-RODRÍGUEZ, C.; PIOVANO, E. L.; GARCÍA-RODRÍGUEZ, F.; SYLVESTRE, F.; ROSTEK, F.; BERNASCONI, S. M.; ARIZTEGUI, D. Paleolimnological record of the Pampean plains (Argentina) as a natural archive of South American hydroclimatic variability since the LGM to the Current Warm Period. Quaternary Science Reviews, v.250, 106675, 2020. DOI. 10.1016/j.quascirev.2020.106675.

33. DANSGAARD, W.; JOHNSEN, S. J.; CLAUSEN, H. B.; DAHL-JENSEN, D.; GUNDESTRUP, N. S.; HAMMER, C. U.; HVIDBERG, C. S.; STEFFENSEN, J. P.; SVEINBJÖRNSDOTTIR, A. E.; JOUZEL, J.; BOND, G. Evidence for general instability of past climate from a 250-kyr ice-core record. Nature, v.364, p.218-220, 1993. DOI. 10.1038/364218a0.

34. EBERL, B. Die Eiszeitenfolge im nördlichen Alpenvorland. Augsburg, B. Filser, 427 S., 2 Kart., Augsburg 1930. 35. EMILIANI, C. Pleistocene temperatures. The Journal of Geology, v.63, n.6, p.538-578, 1955. DOI. $10.1086 / 626295$.

36. ENTING, I. G. On the use of smoothing splines to filter CO² Data. Journal of Geophysical Research, v.92, D9, p.977-984, 1987. DOI. 10.1029/JD092iD09p10977.

37. FONTES, D.; CORDEIRO, R. C.; MARTINS, G. S.; BEHLING, H.; TURCQ, B.; SIFEDDINE, A.; SEOANE, J. C. S.; MOREIRA, L. S.; RODRIGUES, R. A. Paleoenvironmental dynamics in South Amazonia, Brazil, during the last 35,000 years inferred from pollen and geochemical records of Lago do Saci. Quaternary Science Reviews, v.173, p.161-180, 2017. DOI. 10.1016 / j.quascirev.2017.08.021.

38. FORNACE, K. L.; WHITNEY, B. S.; GALY, V., HUGHEN, K. A.; MAYLE, F. E. Late Quaternary environmental change in the interior South American tropics: new insight from leaf wax stable isotopes. Earth and Planetary Science Letters, v.438, p.75-85, 2016. DOI. 10.1016/j.epsl.2016.01.007.

39. GAO, C.; ROBOCK, A.; AMMANN, C. Volcanic forcing of climate over the past 1500 years: an improved ice core-based index for climate models. Journal of Geophysical Research, v.113, D23, p.1-15, 2008. DOI. 10.1029/2008JD010239.

40. GARCÍA, J.; HALL, B. L.; KAPLAN, M. R.; GOMEZ, G. A.; POL-HOLZ, R.; GARCÍA, V. J.; SCHAEFER, J. M.; SCHWARTZ, R. ${ }^{14} \mathrm{C}$ and ${ }^{10} \mathrm{Be}$ dated Late Holocene fluctuations of Patagonian glaciers in Torres del Paine (Chile, 
$51^{\circ} \mathrm{S}$ ) and connections to Antarctic climate change. Quaternary Science Reviews, v.246, 106541, 2020. DOI. 10.1016/j.quascirev.2020.106541.

41. GOUDIE, A. Environmental Change. Oxford: Clarendon Press; Nova York: Oxford University Press, 2ª ed., 1983, 258p.

42. GRAHAM, N. E.; AMMANN, C. M.; FLEITMANN, D.; COOB, K. M.; LUTERBACHER, J. Support for global climate reorganization during the "Medieval Climate Anomaly". Climate Dynamics, v.37, p.1217-1245, 2011. DOI. 10.1007/s00382-010-0914-z.

43. GRAY, L. J.; BEER, J.; GELLER, M.; HAIGH, J. D.; LOCKWOOD, M.; MATTHES, K.; CUBASCH, U.; FLEITMANN, D.; HARRISON, G.; HOOD, L.; LUTERBACHER, L.; MEEHL, G. A.; SHINDELL, D.; VAN GEEL, B.; WHITE, W. Solar influences on climate. Reviews of Geophysics, v.48, n.4, 2010. DOI. 10.1029/2009RG000282.

44. GUPTA, A. K.; ANDERSON, D. M.; OVERPECK, J. T. Abrupt changes in the Asian southwest monsoon during the Holocene and their links to the North Atlantic Ocean. Nature, v.421, p.354-357, 2003. DOI. 10.1038/nature01340. 45. HARTZ, N.; MILTHERS, V., Det senglaciale ler i Allerød Teglværksgrav. Meddelelser fra Dansk Geologisk Forening, v.2, p.31-60, 1901.

46. HEINRICH, H. Origin and consequences of cyclic ice rafting in the northeast Atlantic Ocean during the past 130,000 years. Quaternary Research, v. 29, n.2, p. 142-152, 1988. DOI. 10.1016/0033-5894(88)90057-9.

47. HELAMA, S.; JONES, P. D.; BRIFFA, K. R. Dark Ages Cold Period: A literature review and directions for future research. The Holocene, v.27, n.10, p.1600-1606, 2017. DOI. 10.1177/0959683617693898.

48. HOLMGREN, K.; LEE-THORP, J. A.; COOPER, G. R. J.; LUNDBLAD, K.; PARTRIDGE, T. C.; SCOTT, L.; SITHALDEEN, R.; TALMA, A. S.; TYSON, P. D. Persistent millennial-scale climatic variability over the past 25,000 years in Southern Africa. Quaternary Science Reviews. v. 22, n.21/22, p. 2311-2326, 2003. DOI. 10.1016/S02773791(03)00204-X.

49. HONG, Y. T.; HONG, B.; LIN, Q. H.; SHIBATA, Z.; HIROTA, M.; UCHIDA, M.; LENG, X. T.; JIANG, H. B.; XU, H.; WANG, H.; YI, L. Correlation between Indian Ocean summer monsoon and north Atlantic climate during the Holocene. Earth Planetary Science Letters, v.211, n.3-4, p.371-380, 2003. DOI. 10.1016/S0012-821X(03)00207-3.

50. HUGHES, M. X.; DIAZ, H. F. Was there a 'medieval warm period', and if so, where and when? Climatic Change, v. 26, p.109-142, 1994. DOI. 10.1007/BF01092410.

51. IRIARTE, J. Vegetation and climate change since $14,810{ }^{14} \mathrm{C}$ yr B.P. in southeastern Uruguay and implications for the rise of early Formative societies. Quaternary Research v.65, n.1, p.20-32, 2006. DOI. 10.1016/j.yqres.2005.05.005.

52. IVERSEN, J. En pollenanalytisk Tidsfaestelse af Ferskvandslagene ved Nørre Lyngby. Meddelelser fra Dansk Geologisk Forening, v.10, p.130-151, 1942.

53. JARA, I. A.; MALDONADO, A.; PORRAS, M. A. Late Holocene dynamics of the south American summer monsoon: New insights from the Andes of northern Chile (21 $\left.{ }^{\circ} \mathrm{S}\right)$. Quaternary Science Reviews, v.246, 106533, 2020. DOI. 10.1016/j.quascirev.2020.106533.

54. JARA, I. A.; MORENO, P. I.; ALLOWAY, B. V.; NEWNHAM, R. M. A 15,400-year long record of vegetation, fire-regime, and climate changes from the northern Patagonian Andes. Quaternary Science Reviews, v.226, 106005, 2019. DOI. 10.1016/j.quascirev.2019.106005.

55. JENNINGS, A. E.; KNUDSEN, K. L.; HALS, M.; HANSEN, C. V.; ANDREWS, J. T. A mid-Holocene shift in Arctic sea-ice variability on the East Greenland Shelf. Holocene, v.12, n.1, p.49-58, 2002. DOI. 10.1191/0959683602hl519rp.

56. JESSEN, K. The composition of the forests in Northern Europe in Epipalaeolithic time. Biological Papers 12. Royal Danish Science Society, Copenhagen, 1965. 64p. 
57. JOHNSON, W. H. Stratigraphy and correlation of the glacial deposits of the Lake Michigan lobe prior to 14 ka BP. Quaternary Science Reviews, v.5, p.17-22, 1986. DOI. 10.1016/0277-3791(86)90170-8.

58. KANG, S.; WANG, X.; ROBERTS, H. M.; DULLER, G. A. T.; CHENG, P.; LU, Y.; NA, Z. Late Holocene antiphase change in the East Asian summer and winter Monsoons. Quaternary Science Reviews, v.188, p.28-36, 2008. DOI. 10.1016/j.quascirev.2018.03.028.

59. KANNER, L. C.; BURNS, S. J.; CHENG, H.; EDWARDS, R. L.; VUILLE, M. High-resolution variability of the South American summer monsoon over the last seven millennia: insights from a speleothem record from the central Peruvian Andes. Quaternary Science Reviews, v.75, p.1-10, 2013. DOI. 10.1016/j.quascirev.2013.05.008. 60. KAYANO, M. T.; ANDREOLI, R. V. Clima da região Nordeste do Brasil. In: CAVALCANTI, I. F. A.; FERREIRA, N. M.; SILVA, M. G. A. J.; DIAS, M. A. F. S. (Org). Tempo e clima no Brasil. São Paulo: Oficina de Textos, 2009. 464p.

61. KRIVOVA, N. A.; SOLANKI, S. K. Models of solar irradiance variations: Current status. Astronomy and Astrophysics, v.7, p.151-158, 2008. DOI. 10.1007/s12036-008-0018-x.

62. LAMB, H. H. The early medieval warm epoch and its sequel. Palaeogeography, Palaeoclimatology, Palaeoecology, v.1, p.13-37, 1965. DOI. 10.1016/0031-0182(65)90004-0.

63. LI, Z.; SAITO, Y.; MATSUMOTO, E.; WANG, Y.; TANABE, S.; VU, Q. L. Climate change and human impact on the Song Hong (Red River) Delta, Vietnam, during the Holocene. Quaternary International, v. 144, n.1, p.4-28, 2006. DOI. 10.1016/j.quaint.2005.05.008.

64. LIEW, P. M.; LEE, C. Y.; KUO, C. M. Holocene thermal optimal and climate variability of East Asian monsoon inferred from forest reconstruction of a subalpine pollen sequence, Taiwan. Earth and Planetary Science Letters, v.250, n. 3-4, p. 596-605, 2006. DOI. 10.1016/j.eps1.2006.08.002.

65. LISIECKI, L. E.; RAYMO, M. E. A Pliocene-Pleistocene stack of 57 globally distributed benthic $\mathrm{d}^{18} \mathrm{O}$ records. Paleoceanography and Paleoclimatology, v.20, n.1, p.1-17, 2005. DOI. 10.1029/2004PA001071.

66. LJUNGQVIST, F. C. A new reconstruction of temperature variability in the extra-tropical Northern Hemisphere during the last two millennia. Geografiska Annaler. Series A, Physical Geography. v. 92, n.3, p. 339-351, 2010. DOI. 10.1111/j.1468-0459.2010.00399.x.

67. LOSO, M. G. Summer temperatures during the Medieval Warm Period and Little Ice Age inferred from varved proglacial lake sediments in southern Alaska. Journal of Paleolimnology, v. 41, p.117-128, 117, 2009. DOI. 10.1007/s10933-008-9264-9.

68. LÜNING, S.; GAŁKA, M.; BAMONTE, F. P.; RODRÍGUEZ, F. G.; VAHRENHOLT, F. The Medieval Climate Anomaly in South America. Quaternary International, v.508, p.70-87, 2019. DOI. 10.1016/j.quaint.2018.10.041.

69. LYRA, M. J. A.; FEDOROVA, N.; LEVIT, V.; FREITAS, I. G. F. Características dos Complexos Convectivos de Mesoescala no Nordeste Brasileiro. Revista Brasileira de Meteorologia, v.35, p.727-734, 2020. DOI. 10.1590/0102778635500000 .

70. MANCINI, M. V.; PAEZ, M. M.; PRIETO, A. R.; STUTZ, S.; TONELLO, M.; VILANOVA, I. Mid-Holocene climatic variability reconstruction from pollen records (321-521S, Argentina). Quaternary International, v.132, n.1, p.47-59, 2005. DOI. 10.1016/j.quaint.2004.07.013.

71. MANN, T.; BENDER, M.; LORSCHEID, T.; STOCCHI, P.; VACCHI, M.; SWITZER, A. D.; ROVERE, A. Holocene sea levels in Southeast Asia, Maldives, India and Sri Lanka: The SEAMIS database. Quaternary Science Reviews, v.219, p.112-125, 2019. DOI. 10.1016/j.quascirev.2019.07.007.

72. MARENGO, J. A.; DOUGLAS, M. W.; DIAS, P. L. S. The South American low-level jet east of the Andes during the 1999 LBA-TRMM and LBA-WET AMC campaign. Journal of Geophysical Research, v.107, D20, 8079, 2002. DOI. 10.1029/2001JD001188. 
73. MARTIN, C.; MENOT, G.; THOUVENY, N.; DAVTIAN, N.; ANDRIEU-PONEL, V.; REILLE, M.; BARD, E. Impact of human activities and vegetation changes on the tetraether sources in Lake St Front (Massif Central, France). Organic Geochemistry, v.135, p.38-52, 2019. DOI. 10.1016/j.orggeochem.2019.06.005.

74. MARTIN, C.; MENOT, G.; THOUVENY, N.; PEYRON, O.; ANDRIEU-PONEL, V.; MONTADE, V.; DAVTIAN, N.; REILLE, M.; BARD, E. Early Holocene Thermal Maximum recorded by branched tetraethers and pollen in Western Europe (Massif Central, France). Quaternary Science Reviews, v.228, 106109, 2020. DOI. 10.1016/j.quascirev.2019.106109.

75. MARTINSON, D. G.; PISIAS, N. G.; HAYS, J. D.; IMBRIE, J. D.; MOORE, T.C.; SHACKLETON, N. J. Age dating and the orbital theory of the ice ages: development of a highresolution 0 to 300,000-year chronostratigraphy. Quaternary Research. v.27, n.1, p.1-29, 1987. DOI. 10.1016/0033-5894(87)90046-9.

76. MCCULLOCH, R. D.; BLAIKIE, J.; JACOB, B.; MANSILLA, C. A.; MORELLO, F.; POL-HOLZ, R.; ROMAN, M. S.; TISDALL, E.; TORRES, J. Late glacial and Holocene climate variability, southernmost Patagonia. Quaternary Science Reviews, v.229, 106131, 2020. DOI. 10.1016/j.quascirev.2019.106131.

77. MCGLUE, M. M.; GUERREIRO, R. L.; BERGIER, I.; SILVA, A.; PUPIM, F. N.; OBERC, V.; ASSINE, M. L. Holocene stratigraphic evolution of saline lakes in Nhecolândia, southern Pantanal wetlands (Brazil). Quaternary Research, v.88, n.3, p.472-490, 2017. DOI. 10.1017/qua.2017.57.

78. MCGLUE, M. M.; SILVA, A.; ZANI, H.; CORRADINI, F. A.; PAROLIN, M.; ABEL, E. J.; COHEN, A. S.; ASSINE, M. L.; ELLIS, G. S.; TREES, M. A.; KUERTEN, S. K.; GRADELLA, F. S.; RASBOLD, G. G. Lacustrine records of Holocene flood pulse dynamics in the Upper Paraguay River watershed (Pantanal wetlands, Brazil). Quaternary Research, v.78, n.2, p.285-294, 2012. DOI. 10.1016/j.yqres.2012.05.015.

79. MILANKOVITCH, M. Théorie mathématique dês phénomenès thermiques produits par la radiation solaire. $1^{\underline{a}}$ ed. Paris, France: Gauthier-Villars, 1920.339f.

80. MISRA, P.; TANDON, S. K.; SINHA, R. Holocene climate records from lake sediments in India: Assessment of coherence across climate zones. Earth-Science Reviews, v.190, p.370-397, 2019. 10.1016/j.earscirev.2018.12.017.

81. MOLION, L. C. B.; BERNARDO, S. O. Uma revisão da dinâmica das chuvas no Nordeste brasileiro. Revista Brasileira de Meteorologia, v.17, n.l, p.1-10, 2002.

82. MONTOYA, E.; PEDRA-MENDEZ, J.; GARCÍA-FALCO, E.; GOMEZ-PACCARD, M.; GIRALT, S.; VEGASVILARRÚBIA, T.; STAUFFER, F. W.; RULL, V. Long-term vegetation dynamics of a tropical megadelta: MidHolocene palaeoecology of the Orinoco Delta (NE Venezuela). Quaternary Science Reviews, v.221, 105874, 2019. DOI. 10.1016/j.quascirev.2019.105874.

83. MUÑOZ, P.; GORIN, G.; PARRA, N.; VELASQUEZ, C.; LEMUS, D.; MONSALVE-M, C.; JOJOA, M. Holocene climatic variations in the Western Cordillera of Colombia: A multiproxy high-resolution record unravels the dual influence of ENSO and ITCZ. Quaternary Science Reviews, v.155, p.159-178, 2017. DOI. 10.1016/j.quascirev.2016.11.021.

84. NIELSEN, S. H. H.; KOC, N.; CROSTA, X. Holocene climate in the Atlantic sector of the Southern Ocean: Controlled by insolation or oceanic circulation? Geology, v.32, n.4, p.317-320, 2004. DOI. 10.1130/G20334.1.

85. NIMER, E. Circulação atmosférica do Nordeste e suas consequências: o fenômeno das secas. In: NIMER, E. (Org.) Climatologia do Brasil. Rio de janeiro: IBGE, Departamento de Recursos Naturais e Estudos Ambientais, $2^{\mathrm{a}}$ ed., 1989. 421p.

86. NINKOVITCH, D.; SHACKLETON, N. D. Distribution, stratigraphic position and age of ash layer "L," in the Panama Basin region. Earth Planetary Science Letters, v.27, n.1, p.20-34, 1975. DOI. 10.1016/0012-821X(75)901569. 
87. NOVELLO, V. F.; CRUZ, F. W.; KARMANN, I.; BURNS, S. J.; STRÍKIS, N. M.; VUILLE, M.; CHENG, H.; EDWARDS, R. L.; SANTOS, R. V.; FRIGO, E.; BARRETO, ELINE A. S. Multidecadal climate variability in Brazil's Nordeste during the last 3000 years based on speleothem isotope records. Geophysical Research Letters, v.39, n.23, p.1-6, 2012. DOI. 10.1029/2012GL053936.

88. NOVELLO, V. F.; CRUZ, F. W.; MOQUET, J. S.; VUILLE, M.; PAULA, M. S.; NUNES, D.; EDWARDS, R. L.; CHENG, H.; KARMANN, I.; UTIDA, G.; STRÍKIS, N. M.; CAMPOS, J. L. P. S. Two Millennia of South Atlantic Convergence Zone Variability Reconstructed From Isotopic Proxies. Geophysical Research Letters, v.45, n.10, p.5045-5051, 2018. DOI. 10.1029/2017GL076838.

89. NOVELLO, V. F.; CRUZ, F. W.; VUILLE, M.; STRÍKIS, N. M.; EDWARDS, R. L.; CHENG, H.; EMERICK, S.; PAULA, M. S.; LI, X.; BARRETO, E. S.; KARMANN, I.; SANTOS, R. V. A high-resolution history of the South American Monsoon from Last Glacial Maximum to the Holocene. Scientific Reports, v.7, 44267, 2017. DOI. $10.1038 /$ srep44267.

90. NOVELLO, V. F.; VUILLE, M.; CRUZ, F. W.; STRÍKIS, N. M.; PAULA, M. S.; EDWARDS, R. L.; CHENG, H.; KARMANN, I.; JAQUETO, P. F.; TRINDADE, R. I. F.; HARTMANN, G. A.; MOQUET, J. S. Centennial-scale solar forcing of the South American Monsoon System recorded in stalagmites. Scientific Reports, v.6, 24762, 2016. DOI. 10.1038/srep24762.

91. OLIVEIRA, P. E. BARRETO, A. M. F.; SUGUIO, K. Late Pleistocene/Holocene climatic and vegetational history of the Brazilian caatinga: the fossil dunes of the middle São Francisco River. Palaeogeography, Palaeoclimatology, Palaeoecology, v.152, n.3-4, p.319-337, 1999. DOI. 10.1016/S0031-0182(99)00061-9.

92. OLSON, E. J.; DODDA, J. P.; RIVERA, M. A. Prosopis sp. tree-ring oxygen and carbon isotope record of regional-scale hydroclimate variability during the last 9500 years in the Atacama Desert. Palaeogeography, Palaeoclimatology, Palaeoecology, v.538, 109408, 2020. DOI. 10.1016/j.palaeo.2019.109408.

93. PENCK, A.; BRÜCKNER, E. Die Alpen Eiszeitalter. 1ํㅡ ed. Tauchnitz: Leipzig, 1909, 1199p.

94. PEREZ FILHO, A.; RUBIRA, F. G. Evolutionary interpretation of Holocene landscapes in eastern Brazil by optimally stimulated luminescence: Surface coverings and climatic pulsations. Catena, p.866-876, 2019. DOI. 10.1016/j.catena.2018.06.031.

95. PISIAS, N. G., MARTINSON, D. G.; MOORE JR, T. C.; SHACKLETON, N. J.; PRELL, W.; HAYS, J.; BODEN, G. High resolution stratigraphiccorrelation of benthic oxygen isotope records spanning the last 300,000 years. Marine Geology, v. 56, n.1-4, p.119-136, 1984. DOI. 10.1016/0025-3227(84)90009-4.

96. PRELL, W.; HAYS, J.; BODEN, G. High resolution stratigraphiccorrelation of benthic oxygen isotope records spanning the last 300,000 years. Marine Geology, v. 56, n.1-4, p.119-136, 1984. DOI. 10.1016/0025-3227(84)90009-4. 97. RAILSBACK, L. B. Some Fundamentals of Mineralogy and Geochemistry. Department of Geology, University of Georgia, Athens, Georgia USA. 2015. Disponível em: http://railsback.org/Fundamentals/SFMGSubstages01.pdf. Acesso em 05/04/2021.

98. RAILSBACK, L. B.; BROOK, G. A.; ELLWOOD, B. B.; LIANG, F.; CHENG, H.; EDWARDS, R. L. A record of wet glacial stages and dry interglacial stages over the last $560 \mathrm{kyr}$ from a standing massive stalagmite in Carlsbad Cavern, New Mexico, USA. Palaeogeography, Palaeoclimatology, Palaeoecology, v.438, n.15, p.256-266, 2015b. DOI. 10.1016/j.palaeo.2015.08.010.

99. RAILSBACK, L. B.; GIBBARD, P. L.; HEAD, M. J.; VOARINTSOA, N. R. G.; TOUCANNE, S. An optimized scheme of lettered marine isotope substages for the last 1.0 million years, and the climatostratigraphic nature of isotope stages and substages. Quaternary Science Reviews, v.111, p.94-106, 2015a. DOI. 10.1016/j.quascirev.2015.01.012. 
100. RASBOLD, G. G.; MCGLUE, M. M.; STEVAUX, J. C.; PAROLIN, M.; SILVA, A.; BERGIER, I. Sponge spicule and phytolith evidence for Late Quaternary environmental changes in the tropical Pantanal wetlands of western Brazil. Palaeogeography, Palaeoclimatology, Palaeoecology, v.518, p.119-133, 2019. DOI. 10.1016/j.palaeo.2019.01.015.

101. REEVES, J. M.; BARROWS, T. T.; COHEN, T. J.; KIEM, A. S.; BOSTOCK, H. C.; FITZSIMMONS, K. E.; JANSEN, J. D.; KEMP, J.; KRAUSE, C.; PETHERICK, L.; PHIPPS, S. J. Climate variability over the last 35,000 years recorded in marine and terrestrial archives in the Australian region: an OZ-INTIMATE compilation. Quaternary Science Reviews, v.74, p.21-34, 2013. DOI. 10.1016/j.quascirev.2013.01.001.

102. REYNHOUT, S. A.; SAGREDO, E. A.; KAPLAN, M. R.; ARAVENA, J. C; MARTINI, M. A.; MORENO, P. I.; ROJAS, M.; SCHWARTZ, R.; SCHAEFER, J. M. Holocene glacier fluctuations in Patagonia are modulated by summer insolation intensity and paced by Southern Annular Mode-like variability. Quaternary Science Reviews, v.220, p.178-187, 2019. DOI. 10.1016/j.quascirev.2019.05.029.

103. RODRIGUES, J. M.; BEHLING, H; GIESECKE, T. Holocene dynamics of vegetation change in southern and southeastern Brazil is consistent with climate forcing. Quaternary Science Reviews, v.146, p.54-65, 2016. DOI. 10.1016/j.quascirev.2016.06.011.

104. RODRIGUES, M. L. G.; FRANCO, D.; SUGAHARA, S. Climatologia de frentes frias no litoral de Santa Catarina. Revista Brasileira de Geofísica, v.22, n.2, p.135-151, 2004. DOI. 10.1590/S0102-261X2004000200004.

105. RULL, V.; MONTOYA, E. Holocene vegetation dynamics on the Apakará summit of the neotropical Guayana Highlands and potential environmental drivers. Review of Palaeobotany and Palynology, v.240, p.22-32, 2017. DOI. 10.1016/j.revpalbo.2017.02.007.

106. RYABOGINA, N. E.; AFONIN, A. S.; IVANOV, S. N.; LI, H.; KALININ, P. A.; UDALTSOV, S. N.; NIKOLAENKO, S. A. Holocene paleoenvironmental changes reflected in peat and lake sediment records of Western Siberia: Geochemical and plant macrofossil proxies. Quaternary International, v.528, p.73-87, 2019. DOI. 10.1016/j.quaint.2019.04.006.

107. SANT'ANNA, L. G.; SOARES, E. A. A.; RICCOMINI, C.; TATUMI, S. H.; YEE, M. Age of depositional and weathering events in Central Amazonia. Quaternary Science Reviews, v.170, p.82-97, 2017. DOI. 10.1016/j.quascirev.2017.06.015.

108. SCHAEFER, I. Die donaueiszeitlichen Ablagerungen an Lech und Wertach. Geologia Bavarica. v.19, p.13-64, 1953.

109. SHACKLETON, N. J. The last interglacial in the marine and terrestrial record. Proceedings of the Royal Society of London, v.174, n.1034, p.135-154, 1969. DOI. 10.1098/rspb.1969.0085.

110. SHARMA, S.; SHUKLA, A. D.; BARTARYA, S. K.; MARH, B. S.; JUYAL, N. The Holocene floods and their affinity to climatic variability in the western Himalaya, India. Geomorphology, v.290, p.317-334, 2017. DOI. 10.1016/j.geomorph.2017.04.030.

111. SHEVENELL, A. E.; INGALLS, A. E.; DOMACK, E. W. Orbital and atmospheric forcing of western Antarctic Peninsula climate in the Holocene: The TEX86 paleotemperature record of Palmer Deep. Marine Science Faculty Publications, v.582, p.1-4, 2007. DOI. doi.org/10.3133/of2007-1047.

112. SMITH, R. J.; MAYLE, F. E. Impact of mid- to late Holocene precipitation changes on vegetation across lowland tropical South America: a paleo-data synthesis. Quaternary Research, v.89, n.1, p.134-155, 2018. DOI. 10.1017/qua.2017.89.

113. SORREL, P.; POPESCU, S.; KLOTZ, S.; SUC, J.; OBERHÄNSLI, H. Climate variability in the Aral Sea basin (Central Asia) during the late Holocene based on vegetation changes. Quaternary Research, v.67, n.3, p.357-370, 2007. DOI. 10.1016/j.yqres.2006.11.006. 
114. STEINHILBER, F.; BEER, J.; FRÖHLICH, C. Total solar irradiance during the Holocene. Geophysical Research Letters, v.36, n.19, p.1-5, 2009. DOI. 10.1029/2009GL040142.

115. STOKER, M. S.; AKHURST, M. C.; HOWE, J. A.; STOW, D. A. V. Sediment drifts and contourites on the continental margin off northwest Britain. Sedimentary Geology, v.115, n.1-4, p. 33-51, 1998. DOI. 10.1016/S00370738(97)00086-9.

116. STOTT, L.; TIMMERMANN, A.; THUNELL, R. Southern Hemisphere and deep-sea warming led deglacial atmospheric $\mathrm{CO}_{2}$ rise and topical warming. Science, v.318, n.5849, p.435-438, 2007. DOI: 10.1126/science.1143791. 117. STRÍKIS, N. M.; CHIESSI, C. M.; CRUZ, F. W.; VUILLE, M.; CHENG, H.; BARRETO, E. A. S.; MOLLENHAUER, G.; KASTEN, S.; KARMANN, I.; EDWARDS, R. L.; BERNAL, J. P.; SALES, H. R. Timing and structure of Mega-SACZ events during Heinrich Stadial 1. Geophysical Research Letters, v. 42, n.13, p.5477-5484, 2015. DOI. 10.1002/2015GL064048.

118. STRÍKIS, N. M.; CRUZ, F. C; BARRETO, E. A. S.; NAUGHTON, F.; VUILLE, M.; CHENG, H.; VOELKER, A. H. L.; ZHANG, H.; KARMANN, I.; EDWARDS, R. L.; AULER, A. S.; SANTOS, R. V.; SALES, H. L. South American monsoon response to iceberg discharge in the North Atlantic. PNAS, v.115, n.15, p.3788-3793, 2018. DOI. 10.1073/pnas.1717784115.

119. STRÍKIS, N. M.; CRUZ, F. W.; CHENG, H.; KARMANN, I.; EDWARDS, R. L.; VUILLE, M.; WANG, X.; PAULA, M. S.; NOVELLO, V. F.; AULER, A. S. Abrupt variations in South American monsoon rainfall during the Holocene based on a speleothem record from central-eastern Brazil. Geology, v.39, n.11, p.1075-1078, 2011. DOI. 10.1130/G32098.1

120. SUGUIO, K. Geologia do Quaternário e Mudanças Ambientais \{Passado + Presente = Futuro?). São Paulo: Paulo's Comunicação e Artes Gráficas, 2001, 300p.

121. TAYLOR, B. L. A speleothems-based highresolution reconstruction of climate in southeastern Brazil over the past 4,100 years. 97f. Tese (Doutorado em Geociências). Departamento de Geociências, Universidade de Massachusetts, 2010.

122. THOMPSON, L. G.; MOSLEY-THOMPSON, E.; DANSGAARD, W.; GOOTES, P. M. The Little Ice Age as recorded in the stratigraphy of the tropical Quelccaya Ice Cap. Science, v. 234, n.4774, p. 361-364, 1986. DOI. 10.1126/science.234.4774.361.

123. TINNER, W.; BEER, R.; BIGLER, C. CLEGG, B. F.; JONES, R. T.; KALTENRIEDER, P.; VAN RADEN, U. J.; GILLI, A.; HU, F. S. Late-Holocene climate variability and ecosystem responses in Alaska inferred from highresolution multiproxy sediment analyses at Grizzly Lake. Quaternary Science Reviews, v.126, p.41-56, 2015. DOI. 10.1016/j.quascirev.2015.08.019.

124. TZEDAKIS, P. C.; ANDRIEU, V.; BEAULIEU, J. L.; CROWHURST, S.; FOLLIERI, M.; HOOGHIEMSTRA, H.; MAGRI, D.; REILLE, M.; SADORI, L.; SHACKLETON, N. J.; WIJMSTRA, T. A. Comparison of terrestrial and marine records of changing climate of the last 500,000 years. Earth Planetary Science Letters, v.150, n.1-2, 171-176, 1997. DOI. 10.1016/S0012-821X(97)00078-2.

125. TZEDAKIS, P. C.; CHANNELL, J. E. T.; HODELL, D. A.; KLEIVEN, H. F.; SKINNER, L. C. Determining the natural length of the current interglacial. Nature Geoscience, v.5, p.138-141, 2012. DOI. 10.1038/ngeo1358.

126. UNIVERSITY OF MICHIGAN. Isotopic signatures during glacial and interglacial periods. 2012. In: EarthLabs, Lab 4 - Climate History and the Cryosphere, Part B: Ice Cores, 2018. Disponível em: https://serc.carleton.edu/eslabs/cryosphere/4b.html. Acesso em: 05/04/2021.

127. VAEZI, A.; GHAZBAN, F.; TAVAKOLI, V.; ROUTH, J.; BENI, A. N.; BIANCHI, T. S.; CURTIS, J. H.; KYLIN, H. A Late Pleistocene-Holocene multi-proxy record of climate variability in the Jazmurian playa, southeastern Iran. Palaeogeography, Palaeoclimatology, Palaeoecology, v.514, p.754-767, 2019. DOI. 10.1016/j.palaeo.2018.09.026. 
128. VIAU, A. E.; GAJEWSKI, K.; FINES, P.; ATKINSON, D. E.; SAWADA, M. C. Widespread evidence of $1500 \mathrm{yr}$ climate variability in North America during the past 14,000 yr. Geology, v.30, n.5, p.455-458, 2002. DOI. 10.1130/0091-7613(2002)030<0455:WEOYCV>2.0.CO;2.

129. VUILLE, M.; BURNS, S. J.; TAYLOR, B. L.; CRUZ, F. W.; BIRD, B. W.; ABBOTT, M.B.; KANNER, L. C.; CHENG, H.; NOVELLO, V. F. A review of the South American monsoon history as recorded in stable isotopic proxies over the past two millennia. Climate of the Past, v.8, n.4, p.1309-1321, 2012. DOI. 10.5194/cp-8-1309-2012. 130. XIAODONG, D.; LIWEI, Z.; SHUJI, K. A Review on the Younger Dryas Event. Advances in Earth Science, v.29, n.10, p.1095-1109, 2014. DOI. 10.11867/j.issn.1001-8166.2014.10.1095.

131. WALKER, G. World Weather. Quarterly Journal of the Royal Meteorological Society, v.54, n.226, p.79-87, 1928. DOI. 10.1002/qj.49705422601.

132. WANG, T.; SURGE, D.; WALKER, K. J. Seasonal climate change across the Roman Warm Period/Vandal Minimum transition using isotope sclerochronology in archaeological shells and otoliths, southwest Florida, USA. Quaternary International, v.308-309, v.2, p.230-241, 2013. DOI. 10.1016/j.quaint.2012.11.013.

133. WANG, X.; AULER, A. S.; EDWARDS, R. L.; CHENG, H.; CRISTALLI, P. S.; SMART, P. L.; RICHARDS, D. A.; SHEN, C. Wet periods in northeastern Brazil over the past 210 kyr. Nature, v.432, p.740-743, 2004. DOI. 10.1038/nature03067.

134. WANG, X.; AULER, A. S.; EDWARDS, R. L.; CHENG, H.; ITO, E.; SOLHEID, M. Interhemispheric antiphasing of rainfall during the last glacial period. Quaternary Science Reviews, v.25, n.23-24, p.3391-3403, 2006. DOI. 10.1016/j.quascirev.2006.02.009.

135. WANG, X.; EDWARDS, R. L.; AULER, A. S.; CHENG, H.; KONG, X.; WANG, Y.; CRUZ, F. W.; DORALE, J. A.; CHIANG, H. Hydroclimate changes across the Amazon lowlands over the past 45,000 years. Nature, v.541, p.204-207, 2017. DOI. 10.1038/nature20787.

136. WANG, Y.; CHENG, H.; EDWARDS, R. L.; KONG, X.; SHAO, X.; CHEN, S.; WU, J.; JIANG, X.; WANG, X.; AN, Z. Millennial- and orbital-scale changes in the East Asian monsoon over the past 224,000 years. Nature. v.451, p.1090-1093, 2008. DOI. 10.1038/nature06692.

137. WANNER, H.; BEER, J.; BÜTIKOFER, J.; CROWLEY, T. J.; CUBASCH, U.; FLÜCKIGER, J.; GOOSSE, H.; GROSJEAN, M.; JOOS, F.; KAPLAN, J. O.; KÜTTEL, M.; MÜLlER, S.; PRENTICE, I. C.; SOLOMINA, O.; STOCKER, T. F.; TARASOV, P.; WAGNER, M.; WIDMANN, M. Mid- to Late Holocene climate change: an overview. Quaternary Science Reviews, v.27, n.19-20, p. 1791-1828, 2008. DOI. 10.1016/j.quascirev.2008.06.013. 138. WANNER, H.; SOLOMINA, O.; GROSJEAN, M.; RITZ, S. P.; JETEL, M. Structure and origin of Holocene cold events. Quaternary Science Reviews, v.30, n.21-22, p.3109-3123, 2011. DOI. 10.1016/j.quascirev.2011.07.010.

139. WERNER, M.; WOLFF, E. W. Orbital and millennial Antarctic climate variability over the past 800,000 years. Science, v. 317, n.5839, p.793-796, 2007. DOI. 10.1126/science.1141038.

140. WESTAWAY, R. Improved age constraint for pre-and post-Anglian temperate-stage deposits in north Norfolk, UK, from analysis of serine decomposition in Bithynia opercula. Journal Quaternary Science, v.25, n.5, p.715-723, 2010. DOI. 10.1002/jqs.1348.

141. WHITNEY, B. S.; MAYLE, F. E.; PUNYASENA, S. W.; FITZPATRICK, K. A.; BURN, M. J.; GUILLEN, R.; CHAVEZ, E.; MANN, D.; PENNINGTON, T.; METCALFE, S. E. A $45 \mathrm{kyr}$ palaeoclimate record from the lowland interior of tropical South America. Palaeogeography, Palaeoclimatology, Palaeoecology, v.307, n.1-4, p.177-192, 2011. DOI. 10.1016/j.palaeo.2011.05.012.

142. WONG. C. I.; BANNER, J. L.; MUSGROVE, M. Holocene climate variability in Texas, USA: An integration of existing paleoclimate data and modeling with a new, high-resolution speleothem record. Quaternary Science Reviews, v.127, p.155-173, 2015. DOI. 10.1016/j.quascirev.2015.06.023. 
143. WORTHAM, B. E.; WONG, C. I.; SILVA, L. C. R.; MCGEE, D.; MONTAÑEZ, I. P.; RASBURY, E. T.; COOPER, K. M.; SHARP, W. D.; GLESSNER, J. J. G.; SANTOS, R. V. Assessing response of local moisture conditions in central Brazil to variability in regional monsoon intensity using speleothem ${ }^{87} \mathrm{Sr} /{ }_{86} \mathrm{Sr}$ values. Earth and Planetary Science Letters, v.463, p.310-322, 2017. DOI. 10.1016/j.epsl.2017.01.034.

144. WU, G.; PORINCHU, D. F.; HORN, S. P. Late Holocene hydroclimate variability in Costa Rica: Signature of the terminal classic drought and the Medieval Climate Anomaly in the northern tropical Americas. Quaternary Science Reviews, v. 215, p.144-159, 2019. DOI. 10.1016/j.quascirev.2019.04.023.

145. WU, G.; YOU, T.; THOMPSON, L. G.; LI, Z. Microparticle record in the Guliya ice core and its comparison with polar records since the last interglacial. Chinese Science Bulletin, v.49, p. 607-611, 2004. DOI. 10.1360/03wd0419.

146. ZHANG, Y.; YANG, P.; TONG, C.; LIU, X.; ZHANG, Z.; WANG, G.; MEYERS, P. A. Palynological record of Holocene vegetation and climate changes in a high-resolution peat profile from the Xinjiang Altai Mountains, northwestern China. Quaternary Science Reviews, v.201, p.111-123, 2018. DOI. 10.1016/j.quascirev.2018.10.021.

Esta obra está licenciada com uma Licença Creative Commons Atribuição 4.0 Internacional (http://creativecommons.org/licenses/by/4.0/) - CC BY. Esta licença permite que outros distribuam, remixem, adaptem e criem a partir do seu trabalho, mesmo para fins comerciais, desde que lhe atribuam o devido crédito pela criação original. 